\title{
TERÖRIZMIN VE TERÖR ÖRGÜTÜNÜN PROPAGANDASI SUÇU VE CEZA HUKUKU SORUMLULUĞU
}

\author{
İzzet ÖZGENÇ*
}

\section{$\ddot{O} Z$}

Terör örgütlerinin en önemli özelliği, belirli siyasi amaçlara ulaşabilmek için özellikle şiddet içeren suçlart sistematik bir şeklide işlemeyi yöntem olarak benimsemiş olmalarıdır. Güdülen siyasi amaçlar "meşru”" olsa bile, suç işlemeyi yöntem olarak benimsemiş olmaları dolaylsıyla, hukuk, terör örgütlerine meşruiyet tanınmasına izin vermez. Siyasi iktidarlar veya genel olarak siyasi partiler, terör örgütünün "çözülmesini amaç edindiği” siyasi, sosyal, kültürel veya ekonomik sorunların varlığını kabullenebilirler ve bu sorunların çözümüne yönelik olarak politikalar geliştirebilirler. Ancak bu politikaların oluşturulmasında ve hayata geçirilmesinde terör örgütlerinin ve örgüt mensuplarının muhatap olarak alınmaması gerekir. Aksi takdirde, "meşru amaç, her türlü yolu mübah kılar" anlayışına geçerlilik tanınmış olur. Bu ise toplumda, faaliyeti çerçevesinde şiddet içeren ağır suçların sistematik bir şekilde işlendiği terör örgütlerinin "meşruiyeti" ve "ulviyeti" konusunda haksı, hukuki temeli olmayan bir kanaatin oluşmasina sebebiyet verir.

Bir terör örgütü tarafindan toplumda mevcut olan siyasi, sosyal, kültürel veya ekonomik sorunların “çözümünün amaç” edinilmiş olması, ülkedeki siyasi iktidarl elinde bulunduran veya yönetime talip olan siyasi partiler tarafindan bu sorunların varlığının kabullenilmesine ve bunların hukuk çerçevesinde, meşruiyet zemininde çözümüne yönelik politikalar oluşturmasına engel teşkil etmemelidir.

Ülkede mevcut olan siyasi, sosyal, kültürel veya ekonomik sorunların ve çözüm önerilerinin hukuk zemininde tartışılabilmesiyle, terör örgütlerinin özellikle çocuk yaştaki kişileri ve yabancı güçlerin de terör örgütlerini istismar etmesinin, ülke kaynaklarının heba edilmesinin önüne geçilebilecektir.

Bu hassas dengenin korunması amacıla, terörizmin ve terör örgütünün propagandası bağlamında hangi fiillerin suç oluşturabileceğine ilişkin ölçütlerin sağlıklı bir şekilde belirlenmesi gerekir.

* Prof. Dr., Ankara Hacı Bayram Veli Üniv. Hukuk Fak. Ceza ve Ceza Muhakemesi Hukuku ABD/ ANKARA, e-posta: oezgenc@gmail.com

ORCID : 0000-0002-1805-8572

DOI : :10.34246/ahbvuhfd.933576

Yayın Kuruluna Ulaştığı Tarih :27/01/2021

Yayınlanmasının Uygun Görüldüğ̈̈ Tarih: 15/03/2021 
Iş̧bu makalede, uygulamadan örnekler verilerek, söz konusu ölçütlerin belirlenmesine çalışılmıştır.

Anahtar Kelimeler: Terör örgütü, Terör örgütünün propagandası, Düşünceyi açıklama hürriyeti, Kültürel kimlik ve anadil hakkl, Terör örgütlerinin çocuk istismarl, Silahlı çatışma hukuku

\title{
THE CRIME OF THE PROPAGANDA OF TERRORISM AND TERRORIST ORGANIZATIONS AND THE CRIMINAL RESPONSIBILITY THEREOF
}

\begin{abstract}
The most important feature of terrorist organizations is that they adopt a systematic method of committing particularly violent crimes in order to achieve certain political goals. Even if the motivated political aims are "legitimate", the law does not allow terrorist organizations to be given legitimacy because they have adopted committing crimes as a method. Governments or political parties in general can accept the existence of political, social, cultural or economic problems that the terrorist organization aims to "solve" and develop policies to solve these problems. However, terrorist organizations and their members should not be taken as addressees in the creation and implementation of these policies. Otherwise, the understanding of "legitimate aim makes all means permissible" becomes valid. This leads to the formation of an unfair, unjustified opinion about the "legitimacy" and "sublimity" of terrorist organizations, in which violent serious crimes are systematically committed within the framework of their activities.
\end{abstract}

The "aiming to solve" political, social, cultural or economic problems existing in the society by a terrorist organization should not constitute an obstacle to the acceptance of the existence of these problems by the political parties that hold the political power in the country or to create policies aimed at solving them within the framework of law and on the basis of legitimacy.

By discussing the political, social, cultural or economic problems and solution proposals in the country within the framework of law, it will be possible to prevent terrorist organizations from exploiting children and foreign powers exploiting terrorist organizations and the country's resources will no more be wasted.

In order to preserve this delicate balance, criteria regarding which acts can constitute a crime in the context of terrorism and its propaganda should be determined properly.

In this article, an attempt has been made to determine the mentioned criteria by giving examples from practice.

Keywords: Terrorist organization, Propaganda of terrorist organizations, Freedom 
of speech, Right to cultural identity and mother tongue, Exploitation of children by terrorist organizations, Law of armed conflicts

\section{Giriş:}

Terörizmin ve terör örgütünün propagandası suçuna ilişkin uygulamamız, her zaman ifrat ve tefrit arasında sorunlarla maluldür. Bu sorunlara kanuni düzenlemelerimizin de sebebiyet verdiği gözden uzak tutulmamalıdır. $\mathrm{Bu}$ çalışmada, terörizmin ve terör örgütünün propagandası suçuna ilişkin kanuni düzenlemelerdeki sorunlu alanlar, bu suç dolayısıyla yapılan soruşturma ve kovuşturma süreçlerinde, verilen hükümlerde, bu hükümlerin kanun yolu denetimi ve bireysel başvuru üzerine yapılan denetim bağlamında yaşanan sorunlar tespit edilmeye çalışılmıştır. Keza, tespit edilen bu sorunların hukuk zemininde çözümüne yönelik önerilerde bulunulmuştur.

I. 3713 say1lı Terörle Mücadele Kanununun 1991 yılında kanunlaşan metninde, terör örgütü mensuplarına yardım ile terör örgütünün propagandası fiilleri, uygulama itibarıyla, "seçimlik" hareketli bir suç olarak tanımlanmıştı (m. 7, f. 2). ${ }^{1} \mathrm{Bu}$ tanımlama çeşitli yönlerden hukuk ve kanun yapma tekniği ile uyumlu değildi. Şöyle ki bu düzenlemede örgüte yardım ile örgüt mensuplarına yardım arasındaki ilişki ve fark göz ardı edilmişti. Keza bu düzenlemede, konuları ve mahiyetleri itibarıyla birbirinden farklı olan iki fiil, bir suçun "seçimlik" hareketleri olarak tanımlanmıştı. Bu düzenlemenin en mahzurlu yönü ise, suç tanımında "fiilleri başka bir suç oluştursa bile ayrıca" ibaresine yer verilerek, farklı neviden fikri içtima hükümlerinin uygulanmasına imkân tanınmaması, kişinin bir fiil sebebiyle mükerrer cezalandırılmasının yolunu açması idi. ${ }^{2}$

TMK, m. 7, f. 2'de 2002 yılında 4744 sayılı Kanunla yapılan değişiklikle, terör örgütünün propagandası fiiline "açıklık" getirilmeye çalışılmıştı. Buna

1 Terör örgütü "mensuplarına yardım edenlere ve örgü̈tle ilgili propaganda yapanlara fiilleri başka bir suç oluştursa bile ayrıca bir yıldan beş yıla kadar hapis ve ellimilyon liradan yüzmilyon liraya kadar ağır para cezası hükmolunur."

23713 s. Terörle Mücadele Kanununun terör örgütünün propagandası suçu ile ilgili hükümlerinde yapılan değişikliklere ilişkin bilgi için bkz. YILDIRIM, Zeki: Ifade ve Basın özgürlüğü Bağlamında Terör Örgütünün Propagandası Suçu, 2. bas1, Ankara, Eylül 2020, sh. 239 vd.; TOPÇU, Namık Kemal: Terör Örgütünün Propagandasını Yapma Suçu, in: CHD Ceza Hukuku Dergisi, cilt X, sayı 28, Ağustos 2015, sh.108 vd.

33713 s. Terörle Mücadele Kanununun 7. maddesinin 6.2.2002 tarihli ve 4744 sayılı Kanunla (m. 3; RG: 19 Şubat 2002/24676) değiştirilen ikinci fikrası hükmüne göre; 
göre, "terör yöntemlerine başvurmaya özendirecek şekilde örgütle ilgili propaganda" yapılması, suç oluşturacaktı. Ancak bu tanımda "örgütle ilgili propaganda"nın hangi hallerde suç oluşturmayacağ 1 hususu belirsizlikle maluldü.

Bu fikrada 2003 yılında 4963 sayılı Kanunla yeniden değişiklik yapılmıştı. $\mathrm{Bu}$ değişiklikle "şiddet veya diğer terör yöntemlerine başvurmayı teşvik edecek şekilde propaganda" fiili, suç olarak tanımlanmıştı. ${ }^{4} \mathrm{Bu}$ tanımlamada, propagandanın örgütle ilişkisi koparılmış; propaganda ile, suçu övme ve suç işlemeye teşvik suçları arasındaki ayırım ölçütü belirsiz bir hal almıştı. Ayrıca, şiddet dışında "diğer terör yöntemleri”" ibaresiyle neyin anlatılmak istendiğinin izahı kabil değildi.

5237 sayılı Türk Ceza Kanununun yürürlüğe girmesinden sonra, bu Kanun hükümleriyle uyumunun sağlanması amaciyla Terörle Mücadele Kanununda 2006 yılında 5532 sayılı Kanunla önemli değişiklikler yapılmıştır. Bu kanun değişikliği ile, terör suçu, terör amaciyla işlenen suç, terör örgütü ve terör örgütünün propagandası suçları yeniden tanımlanmıştır.

5532 sayılı Kanun değişikliği ile Terörle Mücadele Kanununun 7. maddesinin ikinci fikrasındaki suç tanımı, terör örgütünün propagandası suçuna özgülenmiştir. Terör örgütü mensuplarına yardım fiili ise, TCK, m. 220 hükümleri çerçevesinde örgüte yardım kapsamında değerlendirilmiştir. 3713 s Kanunun 7. maddesinin ikinci fikrasının birinci cümlesindeki tanıma göre;

"Terör örgütünün propagandasını yapan kişi, bir yıldan beş yıla kadar hapis cezast ile cezalandirllır."

$\mathrm{Bu}$ çalışmada, terörizmin ve terör örgütünün propagandası suçu bakımından iki temel husus üzerinde durulacaktır. Bunlardan birincisi suçun konusunu oluşturan terör örgütü ibaresinden, diğeri ise suçu oluşturan fiil olarak propaganda yapmaktan neyin anlaşılması gerektiği hususudur.

Terör örgütü "mensuplarına yardım edenlere veya terör yöntemlerine başvurmaya özendirecek şekilde örgütle ilgili propaganda yapanlara fiilleri başka bir suç oluştursa bile ayrıca bir yıldan beş yıla kadar hapis ve beşyüzmilyon liradan birmilyar liraya kadar ağır para cezası verilir."

43713 s. Kanunun 7. maddesinin 30.7.2003 tarihli ve 4963 sayılı Kanunla (m. 30; RG: 7 Ağustos 2003/25192) değiştirilen ikinci fikrası hükmüne göre;

Terör örgütü "mensuplarına yardım edenlere veya şiddet veya diğer terör yöntemlerine başvurmayı teşvik edecek şekilde propaganda yapanlara filleri başka bir suç oluştursa bile ayrıca bir yıldan beş yıla kadar hapis ve beşyüzmilyon liradan birmilyar liraya kadar ağır para cezası verilir." 
Propaganda suçunun konusu, terör örgütüdür, terör örgütünün faaliyetleridir, örgütün faaliyetleri çerçevesinde işlenen suçlar ve terör örgütünün kurucu, yönetici ve sair üyeleridir. Suçun oluşabilmesi için, propagandanın belirli bir terör örgütü ile ilişkilendirilmesi gerekir. ${ }^{5}$ Propagandanın özelliği, belirli veya belirsiz kişileri muhatap almasıdır; ${ }^{6}$ yani belirli veya belirsiz kişileri etkilemek amacıyla yapılmasıdır. $\mathrm{Bu}$ yönü itibarıyla propaganda suçu ancak doğrudan kastla işlenebilen bir amaç suçtur. ${ }^{7}$ Ancak suçun tamamlanabilmesi için, başkalarının etkilenmiş olması gerekli değildir. Propaganda suçunun unsurları arasında aleniyet yer almamaktadır. Propagandanın alenen yapılması, toplumda erişebildiği kişi sayısı, temel cezanın belirlenmesinde dikkate alınır. ${ }^{8}$

Propaganda suçu, somut bir suç şüphesine istinaden yapılan adli soruşturma ve kovuşturma neticesinde mahkeme hükmüyle terör örgütü olduğu tespit edilen bir örgütsel yapının varlığının ve faaliyetlerinin "meşruiyetini” kabul etmeleri yönünde kişilere bulunulan çağrıyı ifade etmektedir. Bu çağrı bağlamında terör örgütü ve suç oluşturan faaliyetleri övülmektedir. ${ }^{9} \mathrm{Bu}$ itibarla örneğin Anayasa Mahkemesi kararıyla kapatılmış olan bir siyasi partinin ve faaliyetlerinin övülmesi, bu siyasi partiye ait amblem ve işaretlerin gösterişe sunulması, gösteri amaçlı olarak kullanılması, terör örgütünün propagandası suçunu oluşturmaz. Keza, salt idari bir kararla "terör örgütü" olduğu kabul ve ilan edilen bir örgütsel yapının, bu yapı bünyesinde icra edilen faaliyetlerin övülmesi, bu örgütsel yapıya ilişkin işaretlerin kullanılması, 3713 s. K, m. 7, f. 2'de tanımlanan terör örgütünün propagandası suçunu oluşturmaz.

Terörörgütünün faaliyeti çerçevesinde işlenen suçların ve faillerinin övülmesi halinde, terörizmin ve terör örgütünün propagandası suçu oluşur. Terörizmin ve terör örgütünün propagandası suçunun oluşabilmesi için, örgütün faaliyeti çerçevesinde işlenen ve övülen suçun mutlaka cebir, şiddet veya tehdit

BGH, Urteil vom 2.4.2015, 3 StR 197/14, kn. 12.

6 BGH, Urteil vom 2.4.2015, 3 StR 197/14, kn. 13.

7 Yargitay 16.CD, 14.3.2017, E. 2016/7430, K. 2017/3637. Ayrıca bkz. TOPÇU, CHD, cilt X, say1 28, Ağustos 2015, sh.126 vd.

8 Ancak belirtmek gerekir ki, propagandanın basın ve yayın yoluyla yapılması, söz konusu suçun nitelikli unsurunu oluşturmaktadır. Ayrıca bkz. AİHM, Zana/Türkiye Kararı, 25.11.1997.

9 Bkz. AİHM, Hocaoğulları/Türkiye Kararı, 7.3.2006; AİHM, Sürek/Türkiye Kararı, 8.7.1999. Ayrıca bkz. ARSLAN, Zühtü: İstisnanın Normalleş(tiril)mesi, Terör ve Ífade Özgürlügü: Türkiye Tecrübesi Üzerine Notlar, in: İfade Özgürlügü̈, İlkeler ve Türkiye, İstanbul, 2007, sh.191 vd. 
içermesi gerekmemektedir. Keza, işlenen suçlardan bahisle terörizmin ve terör örgütünün propagandası suçunun işlenebilmesi için, övgüye mazhar kılınan suçların somutlaştırılmış olması gerekmemektedir. Propaganda suçu bakımından önemli olan, kullanılan "direniş", "savaş", "kutlu savaş", "cihat" gibi ifadelerin terör örgütüyle ilişkilendirilmesidir. Kullanılan bu ve benzeri ifadelerin terör örgütüyle ilişkilendirilememesi durumunda, propaganda suçu oluşmaz. Bu bakımdan mesela genel olarak İslâmî cihattan bahsetmek, suç oluşturmaz. Ancak, "PKK", "DAEŞ" veya "IŞSID” olarak isimlendirilen çeşitli örgütsel yapıların faaliyeti çerçevesinde gerçekleştirilen ve çok sayıda insanın ölümü ve yaralanmasıyla sonuçlanan saldırılara işaretle "savaş"tan veya “cihat”tan söz etmek, propaganda suçunu oluşturur.

Bir terör örgütünün faaliyeti çerçevesinde işlenmiş olsa bile, somut bir suçun işlenmesinden dolayı duyulan "memnuniyeti", "sevinci" ifade zımnında icra edilen fiiller, şayet terör örgütüyle ilişkilendirilmemiş iseler, TCK, m. 215'de tanımlanan suçu ve suçluyu övme suçu bağlamında bir değerlendirmeye tabi tutulmalıdırlar.

Terör örgütünün propagandası fiilinin aslında terör örgütüne yardım olarak değerlendirilmesi gerekir. Terör örgütünün propagandasının yapılmasıyla, örgüte bir nevi manevi yardımda bulunulmaktadır. Propaganda faaliyeti, terör örgütüne üye veya destekçi kazandırma çabasını, ifade etmektedir. Propagandada, örgüte üye veya destekçi kazanma amacı güdülmektedir. ${ }^{10}$ Yargitay kararlarında da, terör örgütünün propagandası, örgüte maddi

10 Münchener Kommentar zum StGB (Schäfer), § 129, kn. 124. 


\section{nitelikte olmayan yardım olarak değerlendirilmiştir. ${ }^{11}{ }^{12}$}

11 Yargitay CGK, 3.3.2009, E. 2008/9-184, K. 2009/43; Yargitay CGK, 12.2.2008, E. 2007/9230, K. 2008/23; Yargitay 16. CD, 12.9.2019, E. 2019/7004, K. 2019/5220. Bu mülahazayladır ki,“... Lisesi duvarına terör örgütünün propagandası niteliğinde yazı yazılması” fili, silahlı terör örgütüne yardım etme suçunu oluşturduğu ve bu suçtan dolayı cezaya hükmedilmesi gerektiği kabul edilmiştir (Yargitay CGK, 23.2.2010, E. 2010/9-7, K. 2010/37). Başka bir ifadeyle Yargıtay, terör örgütünü öven ifadelerin sprey boyayla duvarlara yazılması fiilini, terör örgütünün propagandası olarak değil, örgüte yardım olarak değerlendirmiştir (Yargitay 16. CD, 17.10.2019, E. 2019/6477, K. 2019/6216). Keza, Yargıtay'a göre, terör örgütünün propagandası mahiyetinde içeriği sahip bulunan basılmış (matbu) materyalin dağıtılması, 3713 s. TMK, m. 7, f. 2'de tanımlanan suçu değil, terör örgütüne yardım suçunu oluşturmaktadır (Yargıtay 16. CD, 26.2.2018, E. 2017/3230, K. 2018/1016).

Bkz. YURTLU, Fatih: Suç Örgütünün Propagandasını Yapma Suçu, in: Gazi Üniversitesi Hukuk Fakültesi Dergisi, cilt XX, sayı 3, Temmuz 2016, sh. 424; ÖZBEK, Uğur: Iffade Özgürlüğ̈̈ Bağlamında Terör Örgütünün Propagandası Suçu, Ankara, Ocak 2020, sh. 110 vd.; TAŞTAN, Mehmet: Terörle Mücadele Kanununun 7/2 Maddesi, (Terör örgütünün Propagandasını Yapmak Suçu), in: CHD Ceza Hukuku Dergisi, cilt III, sayı 6, Nisan 2008, sh.104.

12 Nitekim, Yargıtay Ceza Genel Kurulu, işlediği fiiller esasında terör örgütünün propagandası mahiyeti taşımasına rağmen, fiilin işleniş biçimini göz önünde bulundurarak, kişiyi terör örgütüne yardım etmekten dolayı mahkûm edilmesi gerektiği yönünde içtihatta bulunmuştur:

Yargitay Ceza Genel Kurulu'nun 30.4.2019 tarihli ve E. 2017/693, K. 2019/352 sayıl1 Kararına konu teşkil eden olayda; PKK terör örgütü mensupları tarafından örgütün etkili olduğu bölgelerde “Önder Apoyu yaşa ve yaşat”, "Êdi Bes E!", “Artık Yeter!" gibi adlarla çeşitli kampanyalar başlatılır. Bu suretle, örgüt mensuplarınca "lider" olarak kabul edilen ve halen hükümlü olarak ceza infaz kurumunda bulunan şahsın tekrar gündemleştirilmesi, bu kişiye izafe edilen görüş ve düşüncelerin toplumda canlı tutulması amaçlanır. Bu kampanya çerçevesinde, özellikle tutuklu veya hükümlü olarak ceza infaz kurumlarında bulunan şahıslar tarafından adlî mercilere "Ben de Sayın Öcalan diyorum", "Eğer sayın olarak hitap etmek suç ise ben de Sayın Öcalan diyorum ve bu suçu işleyip kendimi ihbar ediyorum" ibarelerini içeren matbu dilekçeler gönderilir. Keza, bu etkinliğin bir parçası olarak, Diyarbakır'da "Büyük Postane" önünde yapılan "basın açılaması"nda;

“... Biz Kürtlere reva görülen, baskıcı yasaları ve yasakları ret ediyoruz. İrademize, söylemlerimize demokratik ve insani istemlerimize bile tahammül etmeyen zihniyet sürekli karşımıza anti demokratik yasalarını çıkararak bizleri en insani talep ve mücadelemizden uzaklaştırmak istiyor. Bu dayatmaları kabul etmedik etmeyeceğiz. En belirgin dayatma ve baskılar, on yıldır bir adada inşa edilen zindanda baskı altında yaşamaya mahkum edilmiş ve milyonların iradesi olarak kabul görmüş sayın Öcalan'a uygulanan her türlü kısıtlayıcı, baskıcı uygulamalardır. En son uygulama olarak da zorla saçlarının kazıttırılması olayını gayrı ahlaki ve gayrı insani bir uygulama olarak görüyor ve protesto ediyoruz. Biz Kürtler kimliğimize, dilimize inkarcı yaklaşanlardan, kime nasıl hitap edeceğimize dair izin almaya mecbur değiliz. Bu bağlamda kendini ihbar edenler olarak, imza dilekçelerimiz genel toplamda 25000 adettir. Biz ifade edilen sayıdaki kişiler olarak suç sayılan bu fiili tekrarlıyoruz. İmzaladığımız dilekçe örneğini bir daha tekrarlıyoruz. Diyarbakır Cumhuriyet Başsavcılığı'na Küresel gelişmelerle birlikte Ortadoğu'daki güç dengelerinin değişmesi, Türkiye'nin içerisine düştüğü ulusal ve uluslararası çıkmazlarla barış ve demokrasiye olan tahammülsüzlüğü son noktaya gelmiştir. Başta Kürtlerin temel hak ve özgürlük taleplerinin reddi, inkarı ve çözümsüzlüğü olmak üzere, toplumdaki diğer temel sorunların kendi dinamikleri ile çözme 


\section{Terör örgütünün "çözmeyi amaç" edindiği hukuki, siyasi, sosyal veya}

yerine, her türlü şiddet ve bask1 yöntemini tercih etme yolunu benimsemiştir. Daha önce Kürt kelimesine karșı olan tahammülsüzlüğün yerini bugün de sayın Öcalan hitabı almıştır. Temel sorunları çözme yerine yargı baskısı ile örtbas ederek sonuç alma yoluna gidilmiştir. Bu baskı o kadar ilerletilmiştir ki insanların hitapları dahi dava konusu yapılmıştır. Bunun en somut örneği, 9 yıldır tek bașına Özel Tip İmralı Kapalı Cezaevinde bulunan sayın Öcalan'a ‘sayın' olarak hitap edilmesidir. Bugüne kadar binlerce soruşturma başlatılıp yüzlerce yurttaş, yönetici, aydın, siyasetçi ceza almıştır. En son avukatlarının resmi mercilere yaptıkları başvurularda geçen sayın sözcüğü nedeniyle dahi soruşturma başlatılmıştır. Eğer sayın olarak hitap etmek suç ise ben de sayın Öcalan diyorum ve bu suçu işleyip kendimi ihbar ediyorum"

ifadelerine yer verilir.

Aralarında A'nın da bulunduğu grup içindeki kişiler, "Eğer sayın olarak hitap etmek suç ise ben de sayın Öcalan diyorum ve bu suçu işleyip kendimi ihbar ediyorum" içerikli matbu dilekçeleri imzalayarak zarf içinde PTT aracılığıyla Diyarbakır Cumhuriyet Başsavc1lığına gönderirler.

Cumhuriyet Başsavcılığı, A hakkında suçu ve suçluyu övme ve silahlı terör örgütüne üye olmamakla birlikte örgüt adına suç işlediği iddiasıyla iddianame düzenlemiştir.

İlk Derece Mahkemesi, A'nın silahlı terör örgütünün propagandasını yapmak suçunu işlediğini kabul ederek, 3713 sayılı Kanun, m. 7, f. 2 ... hükümleri uyarınca 1 yıl 3 ay hapis cezası ile cezalandırılmasına hükmedilmiştir.

Yargıtay 9. Ceza Dairesi, A'nın ve grup içindeki diğer kişilerin fiillerinin "silahlı terör örgütüne yardım suçunu oluşturduğu" gerekçesi ile, bu mahkumiyet hükmünün bozulmasına karar vermiştir.

İlk Derece Mahkemesi, bu bozma kararına uyarak, A'nın fiilinin "örgüt içerisindeki hiyerarşik yapıya dahil olmamakla birlikte örgüte bilerek ve isteyerek yardım etmek" suçunu oluşturduğunu kabul ederek, TCK, m. 314, f. 3 delaletiyle m. 220, f. 7; m. 314, f. 2; 3713 sayılı Kanun, m. 5... hükümleri uyarınca 3 yıl 1 ay 15 gün hapis cezası ile cezalandırılmasına hükmetmiştir.

Yargitay 9. Ceza Dairesi, İlk Derece Mahkemesinin bu mahkûmiyet hükmünün onanmas1na karar vermiştir.

Yargıtay Cumhuriyet Başsavcılı̆̆ı, aşağıdaki gerekçe ile bu onama kararına itiraz etmiştir:

Terör örgütünün propagandası suçu ile terör örgütüne yardım suçları bakımından "en ayırıcı ölçüt, yardım fiillerinin maddi nitelikte bulunup bulunmamasıdır. Maddi nitelikteki yardım fiilleri ... 5237 sayıl TCY'nın 220/7. maddesi kapsamında, maddi nitelikte olmayan fiiller ise 3713 sayıl Yasanın 7/2. maddesi kapsamında değerlendirilmelidir."

$\mathrm{Bu}$ itibarla, sanıkların işlediği fiiller, "nitelik ve yoğunlukları da dikkate alındığında maddi yardım niteliğinde görülmediğinden, 3713 sayll Yasanın 7/2. maddesinde düzenlenen suçu oluşturur."

Yargıtay Ceza Genel Kurulu, aşağıdaki gerekçe ile Yargıtay Cumhuriyet Başsavcılığının itirazının reddine karar vermiştir:

"765 sayılı Türk Ceza Kanunu sistematiğinden tamamen farklı bir anlayışla düzenlenen 5237 sayılı Türk Ceza Kanunu’nda, örgütün faaliyetleri doğrultusunda işlenen suçlardan da ayrıca sorumluluk esası kabul edilmiş, yardım etme eylemleri de yaptırım açısından örgüt üyeliği kapsamında değerlendirilerek bağımsız bir şekilde örgüte yardım suçuna yer verilmemiş, gösterdiği vahamet dikkate alınarak örgüte silah sağlama şeklindeki yardım fiilleri 5237 sayıl TCK'nın 315. maddesinde bağımsız olarak, diğer yardım fiilleri ise örgütün 
ekonomik sorunlarla ilgili düşünce açıklamalarında bulunmak, terörizmin ve terör örgütünün propagandası suçunu oluşturmaz. ${ }^{13}$ Örneğin Kürtlerle ilgili olarak anadilde eğitim sorunundan söz etmek, Kürtçenin okullarda

niteliğine göre anılan Kanun'un 220 ile 314. maddeleri kapsamında yaptırıma bağlanmıştır. Örgüt içindeki hiyerarşik yapıya dâhil olmamakla birlikte, örgüte bilerek ve isteyerek yardım eden kişilerin örgüt üyesi olarak cezalandırılacağı hüküm altına alınırken, örgüte yardım sayılan eylemlerin nitelik bakımından örgüt üyeliğine denk sorumluluğu gerektirdiği kabul edilmiştir. Buna göre, örgüt üyesi olmaksızın, bilerek ve isteyerek örgütün bir iş, görev ya da hizmetinin yerine getirilmesi eylemi örgüt üyeliği olarak cezalandırlmakta iken; ... yapılan yardımın niteliğine göre cezanın üçte birine kadar indirilebileceği hüküm altına alınmıştır.

Silahlı terör örgütüne yardım fiilinin oluşması için, failin örgüt üyeleriyle önceden bir anlaşma yapması veya yapılan planlara dahil olması zorunlu değildir. Yardım fiilinin örgüt üyelerinin tamamına veya üyelerden birine yapılması arasında bir fark bulunmamaktadır. Fakat, örgütün amacı ve kollektif faaliyetleri bilinerek ve istenerek yardım edilmesi zorunludur. Yardım edenler zamanlarının büyük bir bölümünü örgüte hasretmiş kişiler olmayıp kendi hayatlarının akışı içerisinde bazen örgüte ait işleri kabul eden şahıslardır."

A'nın söz konusu etkinlikler çerçevesinde hem "...eğer sayın olarak hitap etmek suç ise ben de Sayın Öcalan diyorum ve bu suçu işleyip kendimi ihbar ediyorum" şeklindeki "dilekçenin hem de başka kişilere ait aynı mahiyetteki çok sayıda dilekçenin posta yoluyla gönderilmesine yönelik işlemlerin tamamlanabilmesi için gereken zarflama ve zarflarda yer alan gönderici ve alıcı kısımlarını doldurma işlerini tamamlayıp söz konusu dilekçelerin Diyarbakır Cumhuriyet Başsavclliğına gönderilmek üzere PTT Müdürlüğ̈̈ne teslimi şeklindeki PKK terör örgütünün amacını gerçekleştirmeye hizmet eden faaliyetlerinin, silahlı terör örgütüne yardım etme niteliğinde olduğu kabul edilmelidir."

Yargıtay Ceza Genel Kurulu, bu içtihatta bulunurken, bütün bu olayları kolluğun gözlemlediğini, A'nın bütün bu fiillerini kolluğun gözü önünde cereyan ettiğini, yapılan "basın açılaması"na ve toplanmış olan binlerce dilekçenin zarflanarak postaya verilmesine engel olunmadığını değerlendirmeye tabi tutmamıştır.

Terör örgütünün propagandası ile örgüte yardım arasındaki ilişki bağlamında ayrıca bkz. Yargitay CGK, 7.2.2017 tarihli ve E. 2013/383, K. 2017/60; Yargitay 16. CD, 21.12.2017, E. 2017/2155, K. 2017/5799.

13 Örneğin CEMAL, Hasan: 1930’lar Türkiye'sinden: "Kürtçe konuşma, jandarma gelir!” "Pazarda Kürtçe konuştu diye jandarma gelir, elinden parasını alırd. Bu bana çok acı geliyordu”, in: T24.com.tr, 26 Şubat 2021. 
anadil olarak öğretilmesini ve hatta resmi dil olarak kabul edilmesi gerektiğini savunmak, düşünce ve ifade özgürlüğünün bir tezahürüdür. ${ }^{14}{ }^{15}$ Meğer ki, bu sorunlarla ilgili düşünceler dile getirilirken açıkça terör örgütünün propagandası yapılmış olsun. ${ }^{16}{ }^{17}$

14 Yargitay 9. Ceza Dairesinin 9.5.2012 tarihli ve E. 2010/16268, K. 2012/5801 sayılı Kararına konu teşkil eden olayda; Türkiye'de faaliyette bulunan bir siyasi partinin Mardin Mazıdağ ilçe teşkilatının yönetici ve üyeleri ile halktan yaklaşık 250 kişilik bir grup, 26.1.2009 günü ilçe merkezindeki meydanda toplanır. Bu toplantıda "basın açıklaması" adı altında "Kürtçe Resmi Eğitim Dili Olsun" başlıklı bir bildiri okunur. Bu bildiri içeriğinde şu ifadelere yer verilir:

"Artık Yeter. Bundan sonra kendi anadilimizle eğitim istiyoruz kampanyası TZPK tarafindan daha önce başlatılmıştı. Bunu gören AKP hükümetini hemen telaş sardı ve adım attı, attığ adım ve amacı sahtekarlıkla Kürtçe dili ile din propagandasını yapmaktı. Her ne kadar AKP hükümeti mecbur kalıp adım attıysa da, bu atılan adım Kürt halkı için değildir. Bu Devletin ve AKP hükümetinin bir stratejisidir. İmha ve inkar politikalarını örtmek içindir. Kürt halkı yıllardır özgürlük ve Demokrasi mücadelesini vermektedir. Atılan bu adımların sahte olduğu halkımız tarafindan bilinmelidir. AKP hükümetinin niyeti Kürt halkını kandırmak olduğu tarafimızdan ortaya çıkarılmıştır. Bir taraftan yeni bir Kütçe dili ile yayın yapan TRT-6 yi açmak, diğer bir taraftan da her gün Kürt diline yeni davalar açıyorlar. Tutuklular Kürtçe ile konuşamıyorlar konuştukları için ceza altyorlar, mecliste tutanaklarda hala bilinmeyen dil olarak kayıtlara geçiyor. Diğer taraftan her gün köyler, dağlar Kürdistana uçaklarla bombalar yağdırlyorlar. Bunlar Gazzede İsrail eli ile yapıllyor. Kürdistan'da AKP ile yapıllyor. Bunların hepsi AKP'nin Kürtlere Sahte ve Kara yüzünü gösteriyor. Yine biz kendi halkımıza sesleniyoruz. TRT-6 adı altında oynanan oyuna alet olmayın. Yine biz Devlete ve AKP'ye sesleniyoruz. Söylüyoruz ki artık yeter kirli politikaları inkar ve imha politikalarınızı bırakın. Bu politikalar çözüm değildir. Çözüm için demokrasiyi geliştirin. Artık halkımız bu politikalarla kandırılmıyor. Biz söylüyoruz ki;

1- Kürt dilinin gelişimi için demokratik çözümün olması, oluşacak demokratik modelde Kürt halkının tanınmast,

2- Kürt dilinin resmi bir dil olmast ve Kürt dilinin üzerindeki baskllar ve engellerin kaldırlması ve dilin zenginleştirilmesi, dilin her alanda kullanılması bunun devlet tarafindan görülmesi,

3- Kürt dilinin kirlilikten kurtarllması ve zenginleştirilmesi, Ana dilde eğitimin verilmesi, Kürt enstitüsünün açılması, tüm bunların devletin baskısı altından çıkarılması, oluşacak demokratik örgütlenme modelinde eğitimini verecektir.

4- Devletin attı̆̆ adımlarda samimi olsun, Kürt dili üzerindeki asimilasyonun kaldırılması, Kürt dili üzerindeki oluşan tahribatın giderilmesi, pozitif bir havanın verilmesi,

5- Geçmişte Kürt dili için cezaevine giren ve halen tutuklu olanların ve hakkında dava açanlar derhal cezaevinde bulunanların bırakılması, hakkında dava açılanların davalarının düşmesi gerekir.

6- İsmi değiştirilmiş Kürtçe yerleşim yerlerinin isimlerinin iade edilmesini istiyoruz.

7- Dil eğitimi ve ibadetlerin Kürtçe olarak verilmesi, bunun üzerine çağrıda bulunuyoruz tüm halkımıza diline sahip çıksınlar, Kürt dili resmi ĕgitim dili olsun.”.

Bu bildirinin okunması sırasında, kalabalık içinde bulunan kişiler tarafından "Biji Serok Apo" ("Yaşasın Başkan Apo"), "Be Serok Jiyan Nabe" ("Başkansız Yaşam Olmaz") şeklinde sloganlar atılır ve ayrıca "Be Zıman Jiyan Nabe" ("Dilsiz Yaşam Olmaz"), "Jin Jiyan 
Azade" ("Kadın Yaşam Özgürlük") şeklinde sloganlar atılır ve ayrıca, "zımane me rumetya meye", ("dilimiz onurumuzdur"), "dilimizi istiyoruz", "zimene me hebuna meye", "dilimiz var inkar ediliyor", "em bi zimane dayika xwe penverdekiye dxawazın", "biz kendi ana dilimizde konuşmak istiyoruz" yazılı döviz ve pankartlar taşınır.

(Bu iktibaslar, temyiz konusu olan Diyarbakır 4. Ağır Ceza Mahkemesinin 7.5.2009 tarihli ve E. 2009/121, K. 2009/310 sayılı gerekçeli karar metninden edilmiştir.)

Bu açık hava toplantısına “yaklaşık 250 kişis”nin katılmış olmasına rağmen, sadece üç kişi hakkında dava açılmış ve hüküm kurulmuştur. Bunlardan biri söz konusu bildiriyi okuyan kişi, diğer ikisi ise toplantıya katılarak kalabalık içinde slogan atan kişilerdir.

İlk derece mahkemesi her üç kişiyi de terör örgütünün propagandası suçunu işlediklerini kabul ederek mahkûm etmiştir.

Yargıtay 9. Ceza Dairesi ise, bildiriyi okuyan kişi hakkında kurulan mahkûmiyet hükmünün, bildiri içeriğinin suç oluşturmadığı gerekçesiyle bozulmasına; buna karş1lık, slogan atan diğer iki kişi hakkında terör örgütünün propagandası suçundan dolayı verilen mahkûmiyet hükmünün ise onanmasına karar vermiştir.

Bu karar, yargı eliyle PKK'nin değirmenine su taşınmasının bir örneğini oluşturmaktadır.

15 Gaziantep Bölge İdare Mahkemesi 5. İdari Dava Dairesinin 30.4.2019 tarihli ve E. 2019/2668, K. 2019/1200 sayılı Kararına konu teşkil eden olayda, bir sendikanın "Yürütme Kurulu" tarafından, UNESCO'nun 17.11.1999'da ilan ettiği “21 Şubat Uluslararası Anadili Günü” dolayısıyla alınan karara istinaden, Diyarbakır'da bir haftalık program çerçevesinde çeşitli etkinlikler icra edilir.

Bu etkinlikler çerçevesinde, ... İlkokulunda öğretmen olan A, "22.2.2016 tarihine rastlayan pazartesi "günü 3. saatte bir dersi anadil ile ilgili işleyerek sınıf defterine müfredat dışı kazanım" yazar.

$\mathrm{Bu}$ nedenle, A hakkında "dersin programına göre işlenip ders defterinin de program dahilinde doldurulmasl gerekirken doldurmadıklarının, ögretmenlerin uymast gereken kanun, yönerge ve Terbiye Kurulu kararları doğrultusunda ders programlarina uygun olarak program dahilinde ders işlemeleri gerekirken," ilgili sendikanın almış olduğu karar "doğrultusunda harekete ederek yükümlülüklerini yerine getirmediği" gerekçesiyle disiplin cezası uygulanır.

Diyarbakır İdare Mahkemesi, bu disiplin cezası uygulamasına ilişkin kararın iptali talebiyle açılan davanın reddine karar vermiştir.

Gaziantep Bölge İdare Mahkemesi 5. İdari Dava Dairesi, bu karara karşı istinaf başvurusunun aşağıdaki gerekçe ile kabulüne karar vermiştir:

“Uyuşmazlıkta; davacının üyesi olduğu sendikanın, Türkiye’nin de üyeleri arasında yer aldiğ Birleşmiş Milletler Teşkilatına bağlı bir kuruluş olan UNESCO Genel Kurulunun 1999 yılında aldığı karar sonrası kutlanmaya başlanan 21 Şubat günü "Uluslararası Anadili Günü” kararına atıf yapılarak bu günün anlam ve önemi ile ilgili olarak aldiğı karar doğrultusunda ve bu kararın kapsam ve sınırları aşılmaksızın mahiyeti ile örtüşecek şekilde 21 Şubat Dünya Anadili Günü nedeniyle bir ders saatinde anadilin anlam ve önemini belirtecek şekilde ders işleme eyleminin, eğitim ve öğretim mevzuatını/müfredatını değiştirme amacı ve niteliği taşımadığı, davacının üyesi olduğu sendikanın tabi olduğu tüzük hükümlerinde de anadilin öneminin savunulacağı hükmüne yer verildiği, yapılan bu eylemin ayırıcı veya ayrıştırıcı bir yönünün de bulunmadı̆̆ı, bilakis sendikal faaliyet çevresinde bireylere topluluk halinde sosyal ve kültürrel amaçlarını geliş̧irme imkanı sağladığı, sendika hakkını kullanan bireylerin, çoğulculuk, hoşgörü ve açık fikirlilik gibi demokratik toplumun temel ilkelerinin korunmasını sağlayacağı ve yapılan eylemin, şiddete teşvik etme veya demokratik 
ilkelerin reddi niteliğinde olmadı̆̆ sürece sendikal faaliyet kapsamında değerlendirileceği açıktır.

Bu durumda, üyesi olduğu sendikanın aldığ kararlar uyarınca gerçekleşen bu fiilin sendikal faaliyet kapsamında bir fiil olarak kabulü gerekirken, aksi yönde düșünce ve değerlendirmeyle, üzerine atıl fiilin disiplin suçu teşkil edip ... davacının ... cezası ile tecziyesine yönelik dava konusu işlemde hukuka ve mevzuata uyarlı, davanın reddine yönelik istinafa konu mahkeme kararında hukuki isabet bulunmadığı sonucuna varılmıştır."

Önemle belirtmek gerekir ki, kişinin ilgili mercilere verilmek üzere Kürtçe eğitim isteğine ilişkin dilekçe hazırlaması ve hatta, hazırladığı dilekçeyi mesela Üniversite Rektörlüğüne vermesi, suç oluşturmamaktadır: Yargıtay 9. Ceza Dairesi, 18.6.2002, E. 2002/1391, K. 2002/1499; Yargitay 9. Ceza Dairesi, 23.10.2002, E. 2002/1448, K. 2002/2082.

Keza Yargitay 16. Ceza Dairesinin 13.11.2018 tarihli ve E. 2018/2433, K. 2018/4145 sayıl1 Kararına konu teşkil eden olayda, şehir merkezindeki bir meydanda, dış cephesine "Ölümlere İzin Vermeyeceğiz”, "Taleplere Yanıt Verilsin”, "Açlık Grevi Direnişçilerini Selamlıyoruz", "Anadilde Eğitim Talebi Kabul Edilsin”, "Öcalan’a Özgürlük” ibareleri yazılı pankartlar asılan bir çadır kurulur. Çadırda, hükümlü Abdullah Öcalan'la ilgili olarak " $u y$ gulanan sözde tecrit, avukatları ile görüştürülmemesi, mahkemelerdeki Kürtçe yasağının kaldırılması, okullarda Kürtçe eğitimin serbest bırakılması, terör örgütü mensuplarına yönelik yapılan operasyonları protesto etmek amacıyla" tertip edilen toplantıda, bu minvalde çeşitli konuşmalar yapılır.

Bu olayla ilgili olarak kişiler hakkında sadece kanuna aykırı toplantı ve gösteri yürüyüşü düzenlemekten ve bu toplantı ve gösteri yürüyüşüne katılmaktan dolayı mahkûmiyet hükmü kurulmuş ve bu hüküm, Yargıtay tarafından fiilin suç oluşturmadığı gerekçesiyle bozulmuştur.

16 Avrupa İnsan Hakları Mahkemesinin 8.7.1999 tarihli Sürek ve Özdemir/Türkiye Kararına (BB no. 23927/94; 24277/94) konu teşkil eden olayda; bir derginin mahkeme kararıyla toplatılan 31 Mayıs ve 7 Haziran 1992 tarihli sayılarında, PKK terör örgütü yöneticilerinden Cemil Bayık ile "PKK’nın İkinci Başkanı" sıfatıyla yapılan bir röportaj metni iki bölüm halinde yayımlanır.

$\mathrm{Bu}$ röportaj metninde şu ifadelere yer verilmiştir:

(Avrupa İnsan Hakları Mahkemesinin kararlarındaki başvuru konusu yayın içeriklerine ilişkin iktibaslar, Türkiye'deki yayınların İngilizce veya Fransızca metinlerinden edilmiştir. Avrupa İnsan Hakları Mahkemesinin kararlarında, Türkiye'deki mahkeme kararlarına ilişkin bilgiler, yeterli açıklıkta gösterilmemektedir. Bu nedenle, karara konu teşkil eden yayın içerikleri, İngilizce veya Fransızca tercüme metinlerinin tekrar Türkçeye yapılan tercümelerine dayanmaktadır. Bu karara konu teşkil eden yayın içerikleri, tohav.org internet sitesinde yayımlanan gayri resmi karar tercüme metinlerinden iktibas edilmiştir.)

"Soru: [Seçimler] tehlike arzediyordan kastınız nedir?

Cevap: ABD: "Kürtlere baskı uygulanıyor. Saddam onları öldürüyor. Biz Kürleri Saddam'ın katliamlarına karşı koruyoruz. Onların hayatta kalması bizim güvencemiz altındadır" diyor. Ancak bunun büyük bir sahtekarlık olduğu barizdir. İddia ettikleri şekilde Kürtleri katliama karşı koruyor olsalardı, onları Türk Devletine karşı da korurlardı. Çünkü, Kuzeyde bizim halkımıza karşı Türk Devleti tarafından yapılan katliamlar, Saddam'ınkiler kadar korkunç. Aslında Saddam'ınkilerden daha kötü uygulamalar bile var. Bu nedenle, ABD aynı şeyi Türkiye'ye karşı da yapmalıdır. Çifte standart herkes tarafindan görülecek kadar açıktır. ABD Saddam'a karşı harekete geçiyor, ancak Türkiye'nin Kuzey ve Güneydeki Kürt halklarına karşı yaptı̆̆ katliamları destekliyor. Buna ilişkin birçok emare mevcuttur ve halkımız da bunun bilincindedir. Seçimlerdeki hedefi, hem desteklemek istedikleri teşkilatlar 
üzerinden Güneydeki olumlu gelişmeleri sinırlandırmak, hem de genel olarak Kürdistan'da gelişmekte olan bağımsızlık ve özgürlük mücadelesinin önünü tıkamaktır. Tüm Kürt hareketlerini, halen kendilerinin $[A B D]$ kontrolünde bulunan o iki teşkilatın kontrolü altına almak istiyorlar. Bu nedenle de Kürt halkı için tehlike arz ediyorlar.

Soru: Güney Kürdistan'da bir parlamento kurulur kurulmaz kanunlar yürürlüğe girecektir. Bir yandan Türkiye ve Irak gibi komşular ile ve diğer yandan ABD ile anlaşmalar imzalanacaktır. Türkiye'nin bu ülkelerden tek bir talebi olabilir, o da PKK'nın hariç tutulması. Kürt partileri anılan bir ortam içinde yer alırlarsa, PKK'nın tutumu ne olur?

Cevap: Türkiye ve/veya emperyalizmin, halkımızı ulusal kimlik ve mücadelesinden caydırmak niyetinde olduğu bilinen bir gerçektir. Ancak bir ulus olarak kimliğimizi elde etmek istiyoruz ve bizim baba topraklarımız var. Savaşımız bunun içindir. Bizleri topraklarımızdan söküp atmak istiyorlar; bizleri yok etmek veya bizleri değişmeye zorlamak istiyorlar. Ama biz kendi topraklarımızda barış içinde yaşamak için SAVAŞIYORUZ. ABD veya Türkiye veya Kürt kimliği adına hareket etmekte olduğunu söyleyen herhangi bir başka güç, ülkemizin herhangi bir bölümünden bizi zorla çıkarmaya çalışırsa, bulunduğumuz yerde kalmak için mücadele ederiz. Şu anda da mücadelemizin amacı budur. Türk Devleti bizleri topraklarımızdan atmak istiyor. Insanları köylerinden sürüyor. Kürdistan'ın tamamen boşaltılmasinı istiyor. Ama biz direniyoruz. Kimse bize çıkmamızı söyleyemez veya isteyemez. Biz başkalarının topraklarında değiliz; kendi topraklarımızdayız. Kimse bizden topraklarımızdan ayrllmamızı isteyemez. Kuzey ve Güney diye bir ayrım yapmıyoruz; bizler Kürdistan'dayız. Bizler halkımızın arasındayız. Topraklarımızdan ayrılmamızı istiyorlarsa, bunu asla kabul etmeyeceğimizi bilmeliler. Bizler her şeyini kaybetmiş bir halkız ve kaybettiklerimizi geri kazanmak için çarpışıyoruz. Bizim hareketimizin amacı bu. Kaybedecek bir şeyimiz yok. Kimsenin karşısinda ezilmeyiz ve kimseden korkmuyoruz. Kaybedebileceğimiz tek şey köleliğimizdir. Bu nedenle korkusuzca hareket ediyoruz.

Soru: Türk Devlet televizyonlarında Kürtçe programların yayınlanmasının PKK'ya ödün verme şeklinde yorumlanacă̆ l söylenmektedir. Bu doğru olabilir mi? Ayrıca PKK'nın bir TV kanalı kuracă̆ söylenmektedir. Bu doğru mudur?

Cevap: PKK'nın televizyon yayınına başlayacă̆ı doğru değildir. Bu tür tesislerimiz yok.

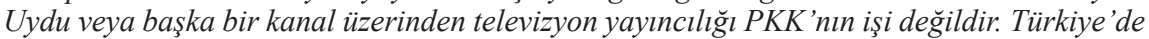
Kürt televizyonu konusunu Turgut Özal ABD ziyaretinde gündeme getirmiştir. Tartışılan husus budur. Halkın küçük bir çoğunluğu Özal'in haklı olduğunu söylüyor, ancak büyük bir kısmı ise buna karşıdır. Kürt TV'nunu önerenler bunu kasıtlı olarak yapıyor. Hedef, sözde kitlelerin etkilenmesi ve kazanılması ve böylece PKK'nın dışlanmasıdır. Fikir budur. Ama, Kürt TV, gerçekleşse dahi, bu onların işine yaramayacaktır. Bu yüzden buna karşılar. Kürt $T V$ 'unu kurmak isteyenlerin amacı PKK'yı dışlamaktır. Çünkü, "Kendi dillerine sahip olan bir halk mevcuttur ve onların dilinde yayın yapmallyız. O halka saygı duymalıyı. Insanlartn dillerinin yasaklanması yanlıştır, bu aynı zamanda Türk halkına da zarar verir." şeklinde bir düşünce yoktur. Durum bunun aksinedir. Tartışmalar gerçek amaçlarını ortaya koymuştur: "PKK'nın etkisini nasıl silebiliriz? PKK'yı nasıl yalnız bıraktırabiliriz? Kürt halklnın gözlerini nasıl bağlayabiliriz?”. Bu taktiksel bir yaklaşımdır. Bu bir oyundur. Ancak ne adım atarlarsa atsınlar, PKK'nın lehine çalışacaklardır. Türk Devleti şimdi Kürdistan'ı kaybetmiştir. Bu bir gerçektir. Bundan sonra Devletin Kürdistan'da yapacağı herhangi bir hareket, PKK'nın lehine ve Türk Devletinin aleyhine çevrilecektir ... Türk basınının ilkeleri yoktur. Bu ahlaksı basın ile iletişsimde bulunmakta herhangi bir fayda olmadiğını düşünüyoruz. Basın ile herhangi bir temasta bulunmamaktan kaçınmakla kalmayacağız; basının Kürdistan'a girişini engellemek için çaba harcayacağız.

Soru: Uludere saldırısinda farklı bir taktik uygulanmıştı. Önceleri, saldırllar geceleri düzenleniyordu. Ama bu kez, saldırı gündüz gerçekleştirildi ve çarpışma gün boyunca sürdü. 
Terörizmin ve Terör Örgütünün Propagandası Suçu ve Ceza Hukuku Sorumluluğu

Bunun gerillalar için daha fazla risk taşıdığı söylenmektedir. Bunun nedeni neydi?

Cevap: Dedikleri doğrudur. Mücadelemiz belli bir düzeye ulaşmıştır. Bu düzeye uygun taktiklerin geliştirilmesi gereklidir çünkü daha düşük taktiklerle savaşmak bir hatadır. Savaşta ilerleme, halen ulaşılmış olan harp düzeyinde taktiklerin kullanımı ile elde edilebilir. Hareketin planlanma nedeni budur. Fikir, sabah saldırmak ve yerimizi korumak ve gün boyunca çarpışmay sürdürmekti - ve sonunda başarılı da oldu. Bu bir deneydi. Bizim görüş açımızdan, bundan çıkarılması gereken sonuçlar mevcuttur. Durumu inceliyoruz. Gelecekte yapacağımız eylemlerde bundan faydalanacağız.

Soru: Faili meçhul kişilerce Kürdistan'da düzenlenen suikastlar ve Hizbullah'ın üzerine aldiğı eylemler hakkındaki düşünceleriniz nelerdir?

Cevap: Hizbullah olarak bilinen bir örgütün olduğu doğru. Fakat güçsüz bir örgüt. Söylenildiği gibi, katliamlar düzenleyen örgüt Hizbullah değil. Örgüt güçsüz olduğu için, Türkiye Cumhuriyeti örgüt mensuplarını çoğu yerde yakaladı. Birçok katliam bu örgütün adı altında yürütülüyor ancak aslında bu cinayetlerin hepsi Türkiye Devleti tarafindan işleniyor. Bunu Hizbullah üyelerine anlatıyoruz: 'Ĕger gerçekten Müslümansanız, şunu bilmelisiniz ki, İslam dini baskının ve adaletsizliğin karşısındadır, doğru ve adil olanın yanındadır. 'Türkiye Devletinin baskıcı olduğu ve çok sayıda katliam ve insanlık dişı eylem gerçekleştirdiği herkes tarafindan bilinmektedir. Hizbullah bu eylemlere karşı çıkanlara saygl göstermelidir. Bu eylemlere karşı savaşmak istiyorlarsa diğer örgütlerle güçlerini birleştirmelidirler. Onlardan istediğimiz sadece budur. Birlikleri arasına sızan kontr-gerillalart püskürtmeleri gerektiği konusunda onları dostça uyarıyoruz. Bunu yapmazlarsa çok fazla üzülecekler. Şu ana kadar ciddi olarak bir tepki vermedik, sadece onları uyardık. Bu olayların Türkiye Devletine hizmet ettiğini söyledik onlara ve belirli kesimlerden olumlu yanıtlar aldik. Hizbullahçıların veya Müslümanların bu tür eylemlere katılmadıklarını ve bu eylemlerin Hizbullahçılar tarafindan gerçekleştirilmediğini söylediler. Bu olumlu bir gelişme. Ancak, Türkiye Devleti, Hizbullah adı altında çeşitli yerlerde katliamlarına hala devam ediyor ...

Soru: Bundan sonra mücadeleniz hangi sinırlar içerisinde devam edecek?

Cevap: Etkileri kesin olarak belirlenmiş olmasa da, iklim koşulları savaşı etkiler. 199192 kışı oldukça sertti; bu da bizim hareketlerimizi ve mücadele kapasitemizi etkiledi, hem bizim açımızdan hem de Türkiye Devleti açısından ciddi problemler yarattı. Ancak onların teknoloji avantajları var ve bunu sonuna kadar kullandılar. Tabii, bir işlerine yaramadı bu. Geçen kış bizi öldürücü darbelere maruz bırakmaya çalıştılar. Bizi yıkacaklarını ve ilkbahara kadar püskürtmeyi başaracaklarını düşündüler. Ancak istediklerini elde edemediler. Sert kış koşullarından dolayı hareket kapasitemiz azaldı ve bunun bir sonucu olarak da geçen yıllarla kiyaslandığında adımlarımızı daha geç atabildik. Fakat yavaş yavaş mevsim normale dönüyor. Çoğu yerde, hala yerde kar var. Ancak bu bizim için fazla engel oluşturmuyor. 1992 yılı diğer yıllarla karşılaştırıldığında daha farklı bir yıl olacak, ama hiç bir zaman şunu söylemiyoruz: 'Silahlı mücadelemizi artıralım ve daha geniş alanlara yayalım'. Ĕger savaşa devam ediyorsak, bunu yapmamız gerektiği içindir.

Farklı bir yaşam ve gelişme için yapabileceğimiz başka bir şey yok. Bizim için tüm yollar kapandı. Savaşı sürdürüyoruz, çünkü bunu yapmaya zorlandık. Savaşın büyüyüp büyümemesi Türkiye Devleti'nin tavrına bağlı. Devlet savaşı daha da körüklüyor. Bu yüzden de savaşı bu noktaya kadar getirdik. Savaş daha da büyüyecek. PKK'dan önce, Kürdistan'a karşı tek taraflı bir savaş vardl. Son birkaç yıldır bu savaş iki taraflı oldu. Eskiden, Türkiye sürdürdüğ̈̈ savaşın sonunda istediği her şeyi elde ediyordu ve bunun sonucunda da Kürdistan halkı hızla ortadan kalkıyordu. Ancak artık Kürt halkı 'Dur!' demeye başladı. Yok olmamak için direnmeye başladılar. Savaşı başlatan devletti, savaşın sona ermesi de devlete bağlı olacak. Savaşı biz başlatmadık. Biz sadece bize karşı sürdürüllen bir yok etme 
savaşında savunmaya geçtik. Türkiye, Kürdistan halkının isteklerini kabul etmedikçe bu savaş devam edecek: geriye tek bir adım bile atılmayacak. Bizim tarafımızda tek bir kişi kalana kadar bu savaş sürecek...

Bazı bölgelerde Devletin sömürgeci otoritesi tamamen yok oldu ... Savaşı idare edenler olarak, halkımızın herkes tarafindan bilinen isteklerinin resmi olarak dile getirilmesini bekliyoruz. Bütün amacımız bu. Bu hedefe, Devletin egemenliğini çeşitli şekillerde ve yollarda zayıflatarak, çeşitli yerlerde popüler bir rejim kurarak ya da diğer bölgelerde ikinci bir rejim oluşturarak ulaşabiliriz. İşte bu halkımızın ve bizim gücümüz. ...

PKK her türlü problemle karşılaşabilir, tüm bu sorunları çözer. Türkiye’ye hiçbir soru sormuyoruz. Onlarla konuşmuyoruz. Herkes ERNK Komitesiyle ya da bu komitenin yerel görevlileriyle konuşuyor. ERNK'nın yetkili olduğu düşünülüyor. Şu an için bizler halk temsilcilerimizi seçiyoruz."

Derginin 31 Mayıs 1992 tarihli sayısında ayrıca şu içerikte bir bildiri yayımlanmıştır.

“... Devlet terörüne karsı, Kürt halkına yapılan baskı ve zulme karsı, katliamlara, sokak ortasında islenen cinayetlere, ... karsı birleşelim; ...

Emperyalizmin ve işbirliği halinde olan yöneticilerin bize karşı yürüttüğü saldırılara karşı gelebiliriz. Bunu başarmak için, ortak isteklerimiz çerçevesinde güçlerimizi birleştirip savaşa katılmalıyı. Tarihteki devrimci rolünün bilincinde olarak, işçi sınıfi harekete geçmeli, eylemleri yönlendirmeli, sendika başkanlarına çağrıda bulunup, eylemlerimize müdahale etmek adına oluşturdukları engelleri ortadan kaldırmalı ve savaşı ve eylemleri yaygınlaştırmalıdir.

- Türk ordusu Kürdistan'dan çekilmelidir. Yargl sistemindeki çifte standarda bir son verilmeli ve tüm Kürt mahkumlar serbest birakılmalıdır.

- Türk parlamentosu, Kürdistan üzerinde kurduğu otoriteden vazgeçmelidir. Kürt halkı kendi kaderini belirlemede özgür bırakılmalıdır, buna ayrı bir Devlet kurulması da dahildir.

- MIT (Milli İstihbarat Teşkilatı) ajanları, kontr-gerillalar ve özel birlikler tarafindan gerçekleştirilen sokak infazlarına ve Devlet terörizmine bir son verilmelidir ve bu kişiler katliamların ve cinayetlerin hesabinı vermelidirler. ...'

$\mathrm{Bu}$ makaleler dolayısıyla derginin yayın sorumluları hakkında İstanbul Devlet Güvenlik Mahkemesi tarafından, TMK, m. 6'da tanımlanan Terör örgütlerinin bildiri ve açıklamalarını yayımlamak ve ( bilahare mülga) m. 8'de tanımlanan "Devletin bölünmez bütünlüğ̈̈ne karşı propaganda yapmak” suçlarından dolayı (27.5.1993 tarihli) mahkûmiyet hükmü kurulmuştur.

Yargitay, yaptığg temyiz incelemesi sonucunda, bu mahkûmiyet hükmünün onanmasına karar vermiştir (4.11.1993 tarihli karar).

AİHM, bu mahkûmiyet hükmüyle, İHAS, m. 10 ile güvence altına alınan ifade özgürlüğünün ihlal edildiğine karar vermiştir. (pn. 64)

“Mahkeme ilk olarak, söz konusu röportajların yasa dışı bir örgütün bir üyesiyle yapılmış olması gerçeğinin başvuranların ifade özgürlüğ̈̈ haklarına yapılan müdahaleyi haklı göstermeyeceğine dikkat çeker; ayrıca röportajların içerisinde resmi politikaya karsı getirilen ağır eleştiriler vardır ve Türkiye'nin güneydoğusunda yaşanan rahatsızlıkların kaynăğ ve sorumluluğuna ilişkin olarak tek taraflı bir yaklaşım benimsenmektedir. Röportajlarda kullanılan kelimelerden mesajın uzlaşmazlık olduğu ve PKK'nın hedefleri garantiye alınmadıkça yetkililerle anlaşma olmayacă̆ açıkça anlaşılmaktadır. ANCAK METINLER

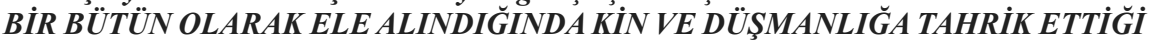
SÖYLENEMEZ. Mahkeme, röportajların bu şekilde yorumlanabilecek bölümleri üzerinde dikkatle durmuştur. Ancak Mahkemeye göre, "Bizden topraklarımızdan çıkmamız istenirse, 
Terörizmin ve Terör Örgütünün Propagandası Suçu ve Ceza Hukuku Sorumluluğu

bunu hiçbir zaman kabul etmeyeceğimiz bilinmelidir" veya "Bizim tarafimızda tek bir kişi kalana kadar savaş devam edecek" veya "Türkiye Devleti bizi topraklarımızdan atmak istiyor. Insanları köylerinden çıkarıyor" veya "Bizi yok etmek istiyorlar" gibi ifadeler, karsı tarafin amaçlarına devam etmek için çözülmesinin ve bu açıdan liderlerinin gösterdiği tavırların bir yansımasıdır. Bu açıdan bakıldığında, röportajlar Türkiye'nin güneydoğusundaki resmi politikaya muhalefetin ardındaki itici güçlerin psikolojisine ilişsin olarak kamuoyunu aydınlatmak ve bu ihtilafta yer alan çıkarları değerlendirmek açısından $\boldsymbol{H A B E R}$ niteliği taşımaktadır." (pn. 61)

Söz konusu röportaj metinlerinde "ifade edilen görüşler, şiddete tahrik olarak değerlendirilemez; şiddete tahrik etmeye meyilli olarak da yorumlanamaz." (pn. 61)

"Mahkemeye göre metnin içinde şiddete tahrik etme olarak yorumlanacak herhangi bir husus yoktur." (pn. 61)

Avrupa İnsan Hakları Mahkemesi, söz konusu kararda PKK'nin bir terör örgütü ve faaliyetlerinin terör eylemleri olduğunu ifade etmekten özellikle kaçınmıştır. Kararda, Türkiye'nin güneydoğu bölgesinden bahisle, "bu bölge yaklaşık 1985 yılından beri çok sayıda kişinin hayatını kaybetmesi ve ... PKK üyeleriyle güvenlik güçleri arasında meydana gelen rahatsız edici durumlar"dan söz edilmiştir. (pn. 61)

Mahkeme söz konusu kararında Türkiye'deki yetkililere de bir ders vermeye tevessül etmiştir: Söz konusu Mahkeme, “... yetkililerin Türkiye’nin güneydoğusunda süregelen durumla ilgili olarak halkl farklı bir perspektiften, bu perspektif her ne kadar hoş olmasa da, bilgilendirmeleri hususunda gereken dikkati göstermedikleri görüşündedir." (pn. 61)

Söz konusu yayın içeriklerinde yer alan ifadelerin, okuyucuda PKK'nin faaliyetinin bir "meșru savaş" olduğu kanaati oluşturmak amacına yönelik olduğu ve şiddeti teșvik edici mahiyet taşıdığı açıktır. Bu itibarla, esasında terörizmin ve terör örgütünün propagandası suçunu oluşturan söz konusu yayın içeriklerinin "ifade özgürlüğü̈" çerçevesinde değerlendirilmesi, terör örgütü PKK'ye "meşruiyet" kazandırma çabasının bir tezahürüdür.

Ancak belirtmek gerekir ki, bu maksatlı yorumlara, Türk yarg1 mercilerinin uygulamaları da zemin oluşturmuştur. Söz konusu olayda, yayın içerikleri bütün olarak bir suç, yani terörizmin ve terör örgütünün propagandası suçunu oluşturmasına rağmen, bir kuzudan iki post çıkarma şeklinde iki ayrı suç işlendiği kabul edilerek, gerçek içtima hükümlerine göre iki ayrı mahkumiyet hükmü kurulmuştur.

17 Avrupa İnsan Hakları Mahkemesinin 8.7.1999 tarihli Erdoğdu ve İnce/Türkiye Kararına (BB. no. 25067/94; 25068/94) konu teşkil eden olayda; bireysel başvuruculardan birincisinin yazı işleri müdürü olarak görev yaptığı dergide, bireysel başvuruculardan ikincisinin İsmail Beşikçi ile yaptığı bir röportaj yayımlanır. Bu röportajda şu açıklamalara yer verilir:

"S: Demirel «Kürt gerçeğini» nasıl ve hangi ölçüde kabul edecektir? Onun «gerçeklik» anlayışının Devlet politikasını temsil ettiği söylenebilir mi?

C: Kürdistan'da şimdi bir silahlı direniş olması nedeniyle Hükümet bazı gerçekleri kabul etmeye zorlanacaktır... Türk kuvvetleri tarafindan uygulanan şiddet PKK'nın yükseliş ve ilerlemesini durduramaz. ...

S: Devlet, Kürdistan'a ilişkin yeni resmi politikasını nasıl şekillendirecektir? Resmi ideolojinin hangi hususları değişecek ve nasıl değiştirileceklerdir? Bunun Kürt halkının günlük yaşamında nasıl etkileri olacaktır?

C: ... Türkiye'de Hükümet ve Devlet iki ayrl şeydir. Devlet, üyeleri atama ile gelen kurumlar ve organlar vasitaslyla işlev görür. Bu kurum ve organlar Devlet'in gücünü temsil ederler. Hükümet, yani siyasi güç Devlet' in gücüne karsı çok hafif bir yük taşımaktadır. Hükümetler 
bu yüzden Devlet idaresi tarafindan sik sik görevden alınabilmektedir. Resmi ideoloji sadece uzun vadede değiștirilebilir ve bunu değiştirmeye muktedir olan güçler hükümet dışı siyasi ve sosyal kuvvetler ve bunların mücadeleleridir. Örneğin PKK'nın fikir ve eylemlerinin özü resmi ideolojiyi değiştirebilecek, Türkiye'nin siyasi sahnesinin atanan kurumlarının etkisini indirgeyebilecek ve halk tarafindan seçilen parlamentonun ăgırlı̆̆ını artırabilecek durumdadir.

Benim gayri resmi, kendi kanaatıma göre Kürtlerin ve özellikle PKK'nın etkisi daha da artacaktır. PKK'nın hem Kürt hem de Türk toplumları üzerindeki etkisi genişleyecek ve derinleşecektir. Ve bu etki büyüdükçe, "Kürt gerçekliğinin» tanınmast yönünde, politikalarında hükümetler tarafindan daha ciddi adımlar atılacaktır. Devletin, bu işlemde Hükümeti engellemeye çalışacağı ve bazı fikir ve politikaları saptırmayı deneyeceği barizdir. Ayrıca, Hükümet'in Devlet'in gücüne karsı koyabildiği ve atanmıs olan kurum ve organları kontrol edebildiği, yani gerçek güce sahip olduğu sürece hayatta kalacağl da ortadadır. Bu değişiklikler Kürtlerin günlük hayatlarına da yanslyacaktır.

Incelemeler ve araştırmalar Kürt dili, tarihi ve halk bilimi gibi alanlarda gelişecektir. Kürt toplumunun özgünlügü Kürt kitleleri arasında daha da vurgulanacaktır. Ulusal bilinçlilik ve özgürlük isteği daha da güçlendirilecek ve yayılacaktır. Bağımsızlık fikri ve hissi gelişecektir.

S: Şimdiye kadar «Ben bir Kürdüm ve şimdiki ve gelecekteki yasamım için politika ile ilgileniyorum» diyen insanların Kürdistan ve Türkiye'de «kendi çıkarları için politikaya atılmaya başladiğl» gözlenmektedir. Bu durumu ne tür gelişmeler ortaya koymuştur? Hukuk alanında Kürtlerin bir siyasi konuya ihtiyacı var mıdır? Ĕger varsa, bu nasıl bir sekil almalıdır?

C: Şüphesiz ki, bu gelişmelerin en önemli nedeni PKK tarafindan yaklaşık olarak sekiz ylldır sürdürülmekte olan silahlı mücadele olmuştur. Gerilla savaşı, geleneksel Kürt toplumunda başlıca sosyal ve siyasi değişikliklere neden olmuştur. Geleneksel değerler bir kargaşa içindedir. 15 Ağustos 1984 tarihinden bu yana halk arasında Kürt gerilla savaşçıları için yaygın bir destek sağlanmıştır. Ulusal bilinç şimdi Kürt toplumunda gelişmektedir ve bu süreç hızla yayılmaktadır. Ve, bu süreç içinde siyasi oluşumun özerklik ve bağımsızlık yönünde Kürt çıkarları için kullanıldığın görmekteyiz. Daha önceleri başkaları ve başka uluslara hizmet etmek üzere siyaset ile ilgilenen Kürtler şimdi Kürt halkına hizmet etmek için siyaset ile ilgilenmektedir. Türk ırkçılı̆̆ ve sömürgeciliğine karst sağlıklı ulusal bilinç gelişmektedir. Tüm bunların, 15 A ğustos tarihindeki Kürt gerilla savasının başlatılmasindan sonra meydana geldiğini söylemek durumu aşırı basitleştirmek olacaktır. Bu süreç, daha gerilere dayanan köklere sahiptir ve belirleyici olan PKK tarafindan başlatılan yeni süreçtir... Kürdistan'da yasadışı olan kimdir? Gerillalar mı yoksa Türk silahlı kuvvetlerinin özel timleri mi?

S: Să̆ kanat medyası ve MÇP (Milliyetçi Çalışma Partisi) tarafindan teşvik edilen şovenist Türk milliyetçi dalgasına karsı koymak için neler yapılmalıdır? Türk ve Kürt halkları arasında bir karsı karsıya gelme olasılığı var mıdır? Bu nasıl engellenebilir?

C: Kürtler ulusu için ölüyorlar. Türkler ne için ölüyor? Onların Kürdistan'da ne işi var?

S: PKK'nın Kürdistan'daki hegemonyasının, artık «çift güçten» bahsedilebilecek düzeye geldiği bir süredir tartışllmaktadır. Öcalan, yazılarında Botan-Behdinan bölgesinde «Ḧ̈kümet-Devlet oluşumundan» bahsetmektedir. PKK'nın Kürdistan'daki ve Türk siyasetindeki gelecekteki müdahalelerine ilişkin herhangi bir işaret mevcut mudur?

C: Türk Devleti Botan gibi bazı bölgelerde şimdiden askerlerini çekmis ve polis karakollarını tahliye etmiştir. ... Bu bir Devlet oluşumunun başlangıcı olarak adlandırılabilir. ..."

İstanbul Devlet Güvenlik Mahkemesi Cumhuriyet Başsavcıllı̆ğ, 23.3.1992 tarihli iddianame 
Anadilde eğitim sorununun çözümü amacıyla çocukların okula gönderilmemesi yönündeki çağrıyı desteklemek, teşvik etmek, bu çağrıya icabet etmek, terörizmin ve terör örgütünün propagandası suçunu değil, duruma göre başka bir suç veya kabahat ${ }^{18}$ oluş̧urabilir.

ile, başvurucuların, söz konusu röportaj1 yayımlamak suretiyle "Devlet' in bölünmez bütünlügüne karsı propaganda yapmak" suçunu işlediklerini iddia ederek, $3713 \mathrm{~s}$. K, (bilahare mülga) m. 8 hükümlerine istinaden cezalandırılmalarını talep etmiştir.

İstanbul Devlet Güvenlik Mahkemesi, başvurucuların $3713 \mathrm{~s}$. K, (bilahare mülga) m. 8'de tanımlanan "Devlet' in bölünmez bütünlüğ̈̈ne karşı propaganda yapmak" suçunu işlediklerini kabul ederek, haklarında mahkumiyet hükmü kurmuştur.

Söz konusu mahkumiyet hükmü, Yargitay tarafindan onanmasına karar verilerek (1.2.1994 tarihli karar), kesinleşmiştir.

Avrupa İnsan Hakları Mahkemesi, bu mahkumiyet hükmüyle, şu gerekçelere (!?) işaret ederek, başvurucuların her ikisinin de ifade özgürlüğü hakkının ihlal edilmiş olduğuna karar vermiştir:

"Suç konusu yayının, bir Türk sosyolog ile yapılan bir röportaj olduğunu ve yayınlanmış haliyle görüslerinin, öncelikli olarak Türk toplumunda yer edinmeye başlayan PKK ideolojisini ve bir Kürt devletinin temellerinin nasıl oluştuğu hususlarına ilişkin olduğuna işaret edilmektedir. PKK'nın Kürt bağımsızlık mücadelesindeki rolünü açıkça savunmaksızın, röportajın yapıldığı şahıs, bu durumu temelde sosyolojik açıdan Türk Devletinin tepkileri bazında analiz etmiştir." (pn. 51).

“... Mahkeme, röportajın içeriğinin analitik nitelikte olduğu ve metnin, şiddete yönelik tahrik içermediği görüsündedir. ...” (pn. 52)

Söz konusu "röportajda belirtilen görüşler, şiddete tahrik seklinde algılanamaz ve şiddeti tahrik edebilecek seklinde yorumlanamaz." (pn. 52).

Söz konusu röportaj içeriğinde yer alan ifadeler, esasında terörizmin ve terör örgütünün propagandası mahiyeti taşımaktadır. Kendisiyle röportaj yapılan kişi, Devletin ülkenin güneydoğusundaki egemenliğinin meşruiyetini sorgulamanın yanı sıra, PKK terör örgütünün 1984 yılından beri icra ettiği terör eylemlerini, Kürt halkının özerklik ve bağımsızlık elde etmek amacıyla güvenlik kuvvetlerine karşı verdiği bir "savaş", bu eylemleri gerçekleştiren kişileri de "Kürt gerilla savaşçıları" olarak nitelendirmiştir. Söz konusu kiși, "fikir ve eylemlerinin özü” itibarıly PKK'nin, "resmi ideolojiyi değiștirebilecek", bu "ideoloji”ye bağlı olarak toplumda ortaya çıkan çeşitli hukuki, siyasi, sosyal ve kültürel sorunların çözümünü gerçekleştirebilecek “durumda" olduğunu belirterek, PKK'nin toplumda teveccühe layık bir örgütlenme olduğu izlenimi oluşturmayı amaçlamıştır.

Belirtilen nedenle, bașvurucular hakkında Türkiye'de kurulan mahkûmiyet hükmündeki suç tanımına ilişkin niteleme, hukuki bakımdan sorunludur. Bu sorun da, Avrupa İnsan Hakları Mahkemesinin somut olay bağlamındaki değerlendirmelerine ve neticesine katılmadığımız kararı vermesine yol açmıştır.

18 5.1.1961 tarihli ve 222 sayılı İlköğretim ve Eğitim Kanunu, m. 55, 56. 
Türkçeyi iyi bilen ve kullanabilen kişilerin haklarında yürütülen soruşturma ve kovuşturma süreçlerindeki savunmalarında, Türkçeyi kullanmama, Kürtçeyi kullanma yönündeki tutumlarının anadilde savunma hakkından ziyade, "anadilde yargılanma" talebini dile getirmek amacı taşıdı̆̆ı izahtan varestedir. ${ }^{19}$

19 Ceza Muhakemesi Kanununun 202. maddesinde değişiklik yapan 24.1.2013 tarihli ve 6411 sayılı Kanuna (m. 1) ilişkin Tasarının TBMM Adalet Komisyonundaki müzakereleri sırasında yapmış bulunduğum açıklamalar aşağıdaki şekildedir:

"Bir kanuni düzenleme yapılırken önce bir sorun teşhisi yapılması lazım gelir. Yani uygulamada ortaya çıkan sorun nedir? Bu sorunu doğru bir șekilde teşhis ettikten sonra bu sorunun çözümünün uygulamayla mı yoksa bir kanuni düzenlemeyle mi yapılması gerektiği üzerinde düşünce üretme yoluna gitmekteyiz. Süreç itibartyla böyle bir yol izlenmesi gerekir.

Bu süreçte ortaya konulacak olan alternatif çözüm modellerinden birisi eğer kanuni düzenleme ise önerilen kanuni düzenleme formülasyonlarının Anayasaya uygunluğu veya aykırtliğı tartışma konusu yapılabilir.

Ama bu aşamaya gelmeden önce bizim önce iki hususu açıllı̆̆a kavuşturmamız lazım gelir. Birincisi, sorun var mi, yok mu ve bu sorun nereden kaynaklaniyor? Savunma hakkının kullanılmasında kullanılan dil bağlamında bir sorunla karşı karşıyayız. Ama bu sorun Ceza Muhakemesi Kanunu'nun 202'nci maddesinin formülasyonundan kaynaklanan bir sorun değil. 202 'nci madde 2005 yllında yürürlüğe giren bir maddedir. Bu maddenin formülasyonu yapılırken Avrupa İnsan Hakları Sözleşmesi'nin 6'ncı maddesiyle, Avrupa İnsan Hakları Mahkemesinin dil hakkının kullanılması bağlamında vermiş bulunduğu kararlar göz önünde bulundurulmuştur. Dolaylsılla, Ceza Muhakemesi Kanunu'nun 202 'nci maddesinin formülasyonunda herhangi bir sorunla karşı karşıya bulunmuyoruz, yani böyle bir tespitimiz yok.

Fakat belirli mahkemelerde savunma hakkının kullanılması bağlamında ana dil kullanılması talepleriyle bağlantılı bir sorunla karşı karşlyayız. Böyle bir gerçekliğimiz var. Bu gerçeklik, davaların özellikle siyasi içerikli davalar olması itibarıyla kamuoyunun gündemine taşınmıştır. Yani şunu bilmemiz lazım gelir ki: Siyasi içerikli olmayan davalardaki savunmalar bakımından dil yönü itibarıyla savunma hakkının kullanılmasında herhangi bir sorun bize yansimış değil. Ancak dil bağlamında, yani, savunma hakkının kullanılması bağlamında ileri sürülen birtakım taleplerle karşı karşıyayız. Ama bu taleplerin hiçbirisi somut davadaki savunmanın efektif bir şekilde yapılmasıyla ilgili de değildir. Bu davalardan bir tanesi, Diyarbakır'da yürüyen dava$d \imath r$, şu veya bu isimle yürüyen dava demek istemiyorum. Ama orada yürüyen bir davadır. Bu davanın yürütülüşü sırasında yargı otoritesi etkinliği bakımından biraz zaafa uğramıştır; bu gerçekliği burada ifade etmem lazım idi.

Hukuk sistemimizde bir duruşma açıldığında bunun nasıl, hangi usul sırası itibarıyla icra edileceği kanunda açık bir şekilde belirtilmiştir. Ama daha bir duruşmada henüz iddianame okunmadan önce, henüz daha sanıkların kimlikleri tespit edilmeden önce sanıklar temsilcisi diye sanıklar adina bir kişi kalkip davanin esastyla ilgili olmayan konularda saatlerce hatta günlerce anlatımda bulunmasina müsaade edilmesiyle yargı otoritesi o davalarda zaafa uğratılmuștır.

Şimdi, sorunumuz şu: Zaafa uğrayan bu yargılama faaliyetinde iddianame okunmadan önce yapılan bütün konuşmalar Türkçe yapılmaktadır ve bu sanıkların -bu konuşma yapan sanıkların- hiçbirisi Türkçeyi bilmediği yönünde, Türkçeyi yeterince bilmediği yönünde Kürtçeyi Türkçeden daha iyi bildiği yönünde bir iddia da bulunmamaktadırlar. Sadece tırnak içinde "ana dilde savunma hakkı" kavramını kullanmaktadırlar. Ama gerçekte dile getirdikleri husus, "ana dilde yargllanma hakkl"dir. Böyle bir hak var midır, yok mudur, o ayrl tartışma konusu olan bir husus. Ama dile getirilen husus ana dilde savunma hakkı değil, ana 
Ancak, böyle bir amacın güdülmesi, başlı başına bir suç oluşturmaz. Bu amaca yönelik tutum ve davranışların, savunma hakkının kullanılması bağlamında değerlendirmeye tabi tutulması gerekir.

dilde yargılanma hakkıdır. Yani sadece meramlarını kendi ana dillerinde sözlü olarak ifade etmekle yetinmek istemiyorlar. Bütün bu yargllama faaliyeti sırasındaki bütün yazılı, sözlü işlemlerin hepsinin kendi ana dilleri çerçevesinde icra edilmesi yönünde bir talepte bulunuyorlar.

Şimdi, bu talep o davanın esasiyla ilgili bir talep değil. O davanın esası bakımından, kendilerine yöneltilen suçlamalarla bağlantılı ĕger bir savunma yapacaksa bunu dinleyebiliriz ama o davadaki yargılama faaliyeti çerçevesinde bir siyasi talep dile getirilmektedir. Bu siyasi talep karşılanır, karşılanmaz, bu konu siyasetin bileceği bir konu; ama eğer bu siyasi talep karşılanacaksa bunun karşılanacağ y yer Ceza Muhakemesi Kanunu'nun 202 'nci maddesi değil. Böyle bir talebin karşılanması bir anayasal sorun olarak karşımıza çıkar. Yani bunu biz anayasa değişikliğiyle ancak dile getirebiliriz ve bu konu resmî dil tartışması bağlamında ele alınması gereken bir konudur. Ĕ̈er biz, resmî dil konusundaki tartışmayı bir kenara iter de Ceza Muhakemesi Kanunu'nun 202 'nci maddesinde tasarı metninde olduğu gibi bir değişiklik yapma yoluna gittiğimizde bu birtakım sorunları belki çözme yönünde bir ilüzyon oluşturabilir. Ama gerçekte ise o düzenleme hayata geçtiğinde daha başka problemlerle karşı karşıya geleceğiz.

En basit karşılaşacağımız problem şudur: Sadece belirli yargılama işlemleri bağlamında kişilere kendi "ana dilinde savunma imkânı" tanıyoruz. Tirnak içinde, "hak" demiyoruz ona çünkü madde "hak" kavramını kullanmıyor "imkân" diyor, "savunma imkânı" veriyoruz. Bu çerçevede mesela bir kişi iddianame okunduktan sonra sözlü savunması bağlamında kendi ana dilini veya istediği bir başka dili -Türkçe dışında bir başka dili-kullanabilecektir. Ama mesela bir bilirkişi raporuna diyeceği sorulduğunda "Onu hayır, onu Türkçe anlatacaksın." diyeceğiz bu kişiye. Yani yargılama faaliyetinin başlangıcında Türkçe dişında bir dili savunma dili olarak kullanacak, yargllama faaliyeti devam ederken Türkçeye tekrar geri döneceğiz ve yargılama faaliyeti sonucunda Cumhuriyet savclsı esas hakkındaki mütalaasını verdikten sonra "Sen ne diyorsun?" diye sözün bağlanacağ bir noktada yine tercih ettiği bir başka dile geri döneceğiz. Bu başlangıçtaki dil olabileceği gibi onun dişında başka bir dil de olabilir. Böyle bir yargılama biçimi yok. Ve bu tartışma karşımıza yarın başka tartışmaları da çıkaracaktır, o da şu: Neden bu sadece kovuşturma evresinde; soruşturma evresinde değil; neden mesela soruşturma evresinde tutuklanma talebiyle hâkimin huzuruna çıkarıldığında bu imkândan yararlandırılmayacağım? şeklinde bir taleple karşı karşıya geleceğim. Yine bu çerçevede, neden bu sorun sadece ceza davastyla sinırlı olarak tutuluyor. ... Özel hukuk davasinda veya diğer bir başka davada ceza hukuku dişındaki diğer davalarda sözlü olarak özellikle taleplerin dile getirilmesi bağlamında bu hak nasıl kullanılacaktır? Sanık bakımından kabul ettiğimiz bu imkânın, tanık bakımından kabul edilebilir olup olmadı ̆̆ konusu da tartışma konusu yapılabilir.

Sözün klsası şu: Çok özür diliyorum, bu konularda aslında Alt Komisyonda da düşüncemizi arz etme imkânı bulmuştuk. Ama orada kayıt edilme imkânı yoktu. Talebin ceza muhakemesi sürecinde ortaya çıkan bir sorunun çözümüne yönelik olmaktan ziyade siyasi bir talep olduğunu ifade etmekle yetinmek isterim."

(Türkiye Büyük Millet Meclisi Adalet Komisyonunun 27.11.2012 tarihinde yapmış bulunduğu toplantıya ilişkin tutanaklar. Ayrıca Bkz. Türk Ceza Hukuku Mevzuatı, Cilt I, Kanunlar, Ankara Hacı Bayram Veli Üniversitesi Türk Ceza Hukuku Uygulama ve Araştırma Merkezi [TÜRK-CE-MER] yayın1, 26. bası, Ankara, Eylül 2020, sh. 736, dn. 1188). 
Keza, vahşiyane yöntemlerle insan öldürmekten çekinmeyen örgütsel yapılanmalarla ilişkilendirilmeksizin, "İslâm Devleti", "Şeriat Devleti" özlemlerinin dile getirilmesinin suç oluşturan bir yönü bulunmamaktadır. Ancak bu özlemin gerçekleştirilmesi bağlamında, terör örgütü vasfını taşıyan örgütsel yapılanmalara "meşruiyet" ve "ulviyet" izafe edilmesi durumunda, terörizmin ve terör örgütünün propagandası suçunun işlendiğini kabul etmek gerekir.

Güvenlik görevlilerinin terörle mücadelede ölçüsüz kuvvet kullandığından, yetkilerini kötüye kullanarak insanları katlettiklerinden söz etmek, güvenlik görevlileri tarafından savunmasız, sivil insanların katledildiğinden bahsetmek, iddialar gerçekle bağdaşmasa bile, suç oluşturmaz. ${ }^{20},{ }^{21}$ Ancak, güvenlik güçleri ile silahlı çatışmaya giren ve bu çatışma sırasında öldürülen terör örgütü mensuplarının "şehit" olduğunu iddia etmek, terörizmin ve terör örgütünün propagandası suçunu oluşturur. ${ }^{22}$ Zira, bu suretle, terör örgütü mensuplarının güvenlik görevlileriyle giriştikleri silahlı çatışma, kutsanmaya çalışılmakta ve insanlar bu mücadeleye destek vermeye teşvik edilmektedirler. ${ }^{23}$

20 "Ülkenin bir bölgesinde terör örgütü mensuplarınca açılan hendeklere ve silahlanmaya müdahale eden, bu anlamda da terörle mücadele eden devleti halka "katliam", "kıyım" ve "işkence" yapmakla suçlayan bir açılamaya katılmak elbette mümkün değildir. Bunlar, belki çok küçük bir grup dışında, toplumun kahir ekseriyetini rahatsız eden çok ağır ifadelerdir.

Bununla birlikte, Anayasa Mahkemesinin hiçbir şekilde içeriğine katılmadığı sözler de ifade özgürlüğü kapsamında kalabilir. Bir ifade ya da açıklamanın ifade özgürlüğü kapsamında kalıp kalmadığı değerlendirilirken söz konusu ifadelerin doğru ya da rahatsız edici olup olmadıkları belirleyici olmaz. Bu noktada kullanılan sözlerin doğru ya da kabule şayan olup olmadığının değil, terör örgütünün cebir, şiddet veya tehdit içeren yöntemlerini meşru gösterecek, övecek ya da bu yöntemlere başvurmayı teşvik edecek şekilde olup olmadığının değerlendirilmesi gerekmektedir.”: Anayasa Mahkemesi, 26.7.2019, BB 2018/17635 (Zübeyde Füsun Üstel ve Diğerleri) (RG: 19 Eylül 2019/30893), pn. 125, 126.

${ }_{21}$ Bkz. AİHM, Gözel ve Özer/Türkiye Kararı, (BB no: 43453/04 ve 31098/05) 6.7.2010; AİHM, Şener/Türkiye Kararı, (BB no: 26680/95) 18.7.2000; AİHM, Ceylan/Türkiye Karar1, (BB no: 23556/94) 8.7.1999.

22 Ancak uygulamada, güvenlik görevlileriyle girdikleri çatışmada öldürülen terör örgütü mensuplarının "şehit" olarak nitelendirilmesinin, terör örgütünün propagandası suçunu oluşturmadığı kabul edilmektedir: Yargitay 16. CD, 13.5.2015, E. 2015/1972, K. 2015/1370; Gaziantep Bölge Adliye Mahkemesi, 3. CD, 11.10.2016, E. 2016/9, K. 2016/6.

23 Ancak belirtmek gerekir ki, işlediği suç ne olursa olsun, suç işleyen kişi gene de bir insandır. İster suç işlediği sırada meşru müdafaa sebebiyle, ister başka herhangi bir sebeple öldürülmüş veya ölmüş olsun, gene de ortada bir insan cesedi bulunmaktadır. İnsan hatırasına duyulması gereken asgari saygıyı, bu kişilerin cesedine de göstermek gerekir.

Ülkemizdeki terörle mücadelede güvenlik görevlileriyle girdikleri silahlı çatışmada öldürülen örgüt mensuplarının cesedi, birileri tarafından "leş" olarak nitelendirilirken, diğerleri tarafından "şehit" cenazesi muamelesi görmektedir. Doğru olmayan bu iki yaklaşımın da, 
Önemle belirtmek gerekir ki, bir ülkedeki hukuki, siyasi, sosyal veya ekonomik sorunlar, terörizmin ve terör örgütlerinin beslendiği ortamı oluşturur. $\mathrm{Bu}$ gerçeklik, mevcut olan sorunların hukuk zemininde ele alınıp çözümlenmesine yönelik çabaların önüne geçmek için bir sebep olarak telakki edilmemelidir. ${ }^{24}$

Bir terör örgütü olan PKK'nin ortaya çıkışındaki amaç, siyasîdir. Başka bir ifadeyle, PKK, Türkiye'deki Kürt sorununun ortaya çıkardığı ve bu sorundan beslenen bir terör örgütüdür. PKK'yi ortaya çıkaran irade, bu siyasi amac1 Türkiye Cumhuriyeti Devletine karşı bir "askeri üstünlük" sağlayarak gerçekleştirme beklentisi içinde değildir; aksine, silah kullanmayı bir "propaganda" yöntemi olarak ${ }^{25}$ güdülen siyasi amacin gerçekleştirilmesinde, Kürt sorununun varlığının ve bunun çözümüne yönelik taleplerin kabulünü sağlamada yegâne araç olarak görmektedir. ${ }^{26}$

$\mathrm{Bu}$ amacın bir ölçüde gerçekleşmiş olduğunu kabul etmek gerekir. Daha önce Türklerden ayrı olarak bir Kürt ırkının varlığının ve Kürtlerin kültürel kimliklerinin tanınması gerektiği yönünde düşünce açıklamasında bulunulması, suç oluşturmakta idi. ${ }^{27}$ Bugün artık bu talepler, ifade özgürlüğünün, düşünceyi

ülkemizdeki ayrılıkçı teröre destek vermekten başka bir mahiyet taşımadığını görmemiz gerekir.

24 Kişilerdeki, toplumda mevcut olan sorunların hukuk zemininde çözümüne yönelik ümidin yitirilmemesi gerekir. Terörizmin ve terör örgütlerinin beslendiği sorunlar varlığını devam ettirdiği ve hukuk zemininde ele alınıp çözümler üretilemediği sürece, "terörist" olarak öldürülen kişi sayısı ne kadar fazla olursa olsun, terörizmin önüne geçilmesi mümkün değildir. Mevcut bir terör örgütünün kamu gücü kullanılarak faaliyet icra edemez hale getirilmesi, ancak bir örgüt mutasyonuna sebebiyet verebilir.

Terörizmin ve terör örgütlerinin beslendiği diğer bir faktör ise, "terörle mücadele" görüntüsü altında kamu gücü kullanılarak yapılan iş ve işlemlerde hukukun dışına çıkılmasıdır. Bu çerçevede, işkence, ölçüsüz güç kullanılması, bir terör örgütünün bastırılmasında diğer bir terör örgütünün araç olarak kullanılması, birer örnek olarak zikredilebilir.

25 "Silahlı propaganda" (BİRAND, Mehmet Ali: APO ve PKK, 6. bası, İstanbul 1992, sh. 124 vd., 135, 153.

26 BİRAND, APO ve PKK, 6. bas1, 152 vd.

27 Terörle Mücadele Kanununun 15.7.2003 tarihli ve 4928 sayılı Kanunla yürürlükten kaldırılan 8. maddesinin birinci fikrası hükmü şu şekilde idi:

"Hangi yöntem, maksat ve düşünceyle olursa olsun Türkiye Cumhuriyeti Devletinin ülkesi ve milletiyle bölünmez bütünlüğünü bozmayı hedef alan yazılı ve sözlü propaganda ile toplantı, gösteri ve yürüyüş yapılamaz. Yapanlar hakkında ... cezası hükmolunur”

Bu maddede bilahare 6.2.2002 tarihli ve 4744 sayılı Kanunla yapılan değişiklikle söz konusu suç şu şekilde tanımlanmıştı:

“Türkiye Cumhuriyeti Devletinin ülkesi ve milletiyle bölünmez bütünlüğünü bozmak amacıyla yazıl1, sözlü veya görüntülü propaganda ile toplantı, gösteri ve yürüyüş yapanlar hak- 
kında, fiilleri daha ağır bir cezayı gerektirmedikçe ... cezasına hükmolunur."

Bu suç tanımına ilişkin olarak uygulamadan üç örnek verebiliriz:

I. Yargitay Ceza Genel Kurulu'nun 3.4.1995 tarihli ve E. 1995/9-70, K. 1995/98 say1l Kararına konu teşkil eden olayda; 8.9.1991 tarihinde usulüne uygun olarak düzenlenen açık hava toplantısında, kalabalığa hitaben birer konuşma yapan sanıklardan A,

"Kardeşler hepinize merhaba diyor ve S.yle selamliyorum. 13 yıllık bir aradan sonra tekrar aranıza gelmiş olmaktan büyük bir mutluluk duyuyorum. Ama bu mutluluğum eksik bir mutluluk. Çünkü, cezaevlerinde birlikte yaşadiğımız, her şeyi paylaştığımız, birlikte direndiğimiz arkadaşlardan Kürt arkadaşlarını orada bırakarak geldim. Bu yarım bir hüzündür. Ama inanıyorum ki, halkın yükselen mücadelesi bir gün onları da cezaevinden çıkaracak, özgürlük alanlarına taşıyacaktır. Biliniyor, biraz önce ifade edildi. Anti- Terör Yasası, yükselen halk muhalefetine karşı şiddeti meşrulaştırmak için yürürlüğe sokulmuş bir yasadır. Bu bir ihtiyaçtan doğmuştur. Bu ihtiyacın kaynakları, başlangıcl, sadece yasanın çıktı̆̆ tarihe ait değildir. 12 Eylül öncesinde 1980'lere gelindiğinde yükselen muhalefet karşısında yine Devlet șiddete bașvurmak zorunda kalmıștır. Ve kendi Anayasa ve Yasalarını bir kenara iterek, beş tane cahil adamın kurduğu ortaklık çerçevesi içinde iktidara el koymuştu. Ve toplum o günden sonra karanlıklara itildi. Siddet önce toplumu sindirdi, bastırdl, Ondan sonra hükmünü icra etmeye başladı. Ve belirli bir dönem sadece cezaevleri muhalefetin toplumsal odağı haline geldi. Toplumsal odağı, muhalefetin odağı olmak demek aynı zamanda basklnın, şiddetin de hedefi olmak anlamına geliyordu. İnsanlar direndiler. Sade içerdekiler değil, dışardakilerle birlikte bu tarih kesitinde insan onurunu hep birlikte savundular. Insanlık onurunu yükselttiler ve yücelttiler. İçerdekiler kadar dışardakiler de kahramandılar. Kardeşler, giderek toplumsal muhalefet yükselmeye başladı. Kürdistan'da Kürt halkı tarihinde ilk kez kendi özgürlük ve demokrasisini kazanmak üzere ayağa kalktı. Kendi öncüsüne ulaştı. Binlerce yıllık ezilmişliğini ve içine itilmiş olduğu insanlık dışı şartları reddederek özgürlüğü ve demokrasisini kazanmak üzere bugün de hepimizin yakından ilgilendiğimiz gibi olumlu bir noktaya geldi. Ama sadece bu kadar değil. Türkiye'de emekçi halk, işçi sınıfi yine tarihinde hiçbir dönem gözükmediği ölçüde kendi mücadelesini örgütledi. Bugün günlük yaşamda görüyoruz. Kendi eylemliliği içinde güncel mücadelenin şartlarını yerine getirmek suretiyle haklarını kazanmak için bütün çabasını sarf ediyor. Dolayısıyla, bütün bunların yaşandığ şartlarda varlığını ilerletmek gücünden yoksun olan ve halka refah getiremeyen ekonomik gelişmeyi sağlayamayan ve devlet içinde örgütlenmiş olan egemen güçler, yapabilecekleri son çareye başvurdular. Ve kendi şiddetlerini yasallaştırabilmek için Anti-Terör Yasasını getirdiler, gündeme koydular. Anti-Terör Yasası, toplumu daha önce halkı cenderelerde tutan, düşünceyi yasaklayan her türlü örgütlenme özgürlügünü yok etmiş olan 141. 142 'yi kaldırmışlar gibi gözükmesine rağmen, bölücülük adı altında halk muhalefetinin bugüne kadar aldığ y yönü de hesaba katarak yeni biçimlerde ve çok daha yoğun olarak şiddeti yasallaş̧ırmaya çalıştı. Ama, yasallık tek başına yetmiyor. Yasallığı meşru kılabilmek için yasalliğın güçlü bir meşruiyete dayanması gerekir. İste, Devletin bugün ihtiyacını duyduğu yasallı̆̆ rağmen hiçbir zaman kendisinde var olmayan şey meşruluktur. Yani bugün Devlet bütün eylem ve işlemleriyle gayrimeşrudur. Tarih dışıdır ve mutlaka tarihten silinmek zorundadır. Yine bugün için yükselen halk mücadelesi karşısında Anti-Terör Yasasıyla yapmak istedikleri toplum çerçevelerine dahi siğmiyor. Bugün meşru olan tek şey halkın yükselttiği şeydir, mücadeledir. Ve halk kendi mücadelesini kendi yasallığıyla birlikte geliştiriyor. Görünüşte Anti-Terör Yasasına karşı yükselen mücadele Anayasa çerçevesine girmemesine rağmen, onun karşısında tamamen meşru bir zemine oturmaktadır ve yasaldır. Yasa dışı olan güç Devlettir ve onun temsil ettikleridir. Bugün buralarda az gözüksek de hepimiz biliyoruz ki, dağlarda kalabalı̆̆ız ve giderek daha da kalabalık olacağl, teşekkür ediyorum" sözlerini; sanıklardan B, 
Terörizmin ve Terör Örgütünün Propagandası Suçu ve Ceza Hukuku Sorumluluğu

"Değerli insan hakları savunucuları, hepinize merhaba diyorum. Arkadaşlar, parsellenmiş bir Türkiye'de, demokrasinin var diye iddia edildiği bir Türkiye'de biz demokrasinin kavgasını veren yürekli insanlar olarak buraya dövüşmek için geldik. Buraya konuşmak için geldik. Buraya haykırmak için geldik. Buraya Türkiye'de nasıl bir demokrasi istiyoruz, onu insanlara söylemek için geldik. Ama görüyorum ki, burada özellikle de güvenlik güçlerinin engellemeleri sonucunda toplanan şu azınlık kendi içimizde bizi konuşturmuyor. Bir suskunluk var içimizde. Bir suskunluk var hepimizde. Arkadaşlar, burada bulunanlar sayısal olarak az olabiliriz, üç beş parmak olabiliriz, ama şunu unutmayın! Bunlar bize televizyonu yasaklayan insanlar. Bugün bizim sayımızdan değil, düşüncelerimizden korkuyorlar. Çünkü, onlar bunu çok iyi biliyor. Yıllardır kendi çıkarlarına hizmet eden, insan haklarıyla yıllardır en kü̧̈ük demokratik haklarını arayan insanların üzerindeki devlet terörüyle, insanların özgürce düşünme yolunu kapattılar. İște bu yasaklar zinciri altında, işte bu devlet terörü altında biz, yani yüreği sevinçlerin ateşiyle çarpan insanlar, Mahir'lerin ateşleriyle çarpan insanlar, halen konuşmaya devam ediyoruz, edeceğiz de. Devlet terörü diyorlar, Anti -Terör Yasası diyorlar. Arkadaşlar, Anti-Terör Yasası sözüm ona Terörle Mücadele Yasası neyi kolluyor, neyi kolluyor, hiç düşündünüz mü? Burada terörist arlyorlar, fabrikada terörist arıyorlar, okulda terörist arıyorlar, köyde terörist arıyorlar. Ama asıl teröristler Ankara'da meclisin duvarlart içerisinde asıl teröristler. Neden ordalar? Arkadaşlarım, bugün, bugün özellikle de köşe bucak fikir kulislerinin yapıldığ Türkiye’ye nasıl geldik? Nasıl getirdiler bizi? Bunları hepimiz yaşayarak ögrendik. Bugün Erken Seçim Yasası diyorlar, muhalefet yollarını kapatıyorlar, alanları kapatıyorlar. Sözüm ona özgür Türkiye'de insanların özgür iradelerine başvuruyorlar. Sizlere soruyorum arkadaşlar biz bu Anayasaya evet dedik mi? Peki o zaman Mecliste oturup bizi yönetme yetkisini, bizim adımıza bizi yönetme yetkisi zorla alan insanlar asıl teröristler değil mi? İște arkadaşlarım, bunun içindir ki kendilerini saklayabilmek için, kendilerini gizleyebilmek için öylesine bir Terör Yasası çıkardılar. Sözüm ona ki, bu bozguncu düzende, bu yalancı düzende, bu asıl onları korumaktır. Bugün elleri ayakları titremeye başladı. Iște arkadaşlarım, biz kendi içimizde susmaya devam ettiğimiz sürece, kafamızdaki muhalefet anlayışını o zamanlar önünü görmekten aciz tarladaki, bahçedeki, fabrikadaki işçi(ye) bilinçli (bir şekilde) taşıyamadığınız sürece, onları, sınıfimız iktidara sahip olmalıdır telaffuzuna alıştırmadiğımız sürece, bunlar bizi daha çok yönetecek. Biz yine buraya gelip bağıracağız, çağıracağız ama dağıldıktan sonra mevcut düzenin, o pis burjuva alışkanlıklarl içinde yine günümüzü gün etmeye çalışacă̆ız. Bizler eğer kendimize devrimci diyorsak, bugün Anayasaya hayır demek zorundayız. Seçim Yasasına hayır demek zorundayız, göstermelik demokrasiye hayır demek zorundayız, Kürt halkının bağımsızlık mücadelesini engelleyen insanlara hayır demek zorundayız, sendikalar üstündeki basklya hayır demek zorundayız. Biz, kısacası biz bizim olmayan demokrasi dışındaki, şu andaki kapitalizme ve $A B D$. emperyalizmine hizmet etmekten başka hiçbir amacı ve çılkarı olmayan bu göstermelik demokrasiye işçisiyle-köylüsüyle, öğrencisiyle-sıradan vatandaşıyla, kısacası Türk ve Kürt halklarlyla birlikte hayır demek zorundayı"

sözlerini kullanırlar.

Yargıtay Ceza Genel Kurulu, her iki sanığın bu açıklamalarının, "3713 sayılı Terörle Mücadele Kanununun 8/1. maddesindeki hangi yöntem, maksat ve düşünce ile olursa olsun, T.C. Devletinin ülkesi ve milletiyle bölünmez bütünlüğ̈̈ü hedef alan sözlü propaganda suçunu" oluşturduğu yönünde içtihatta bulunmuş̧tur.

II. Yargitay Ceza Genel Kurulu'nun 3.10.1994 tarihli ve E. 1994/9-183, K. 1994/214 say1l kararına konu teşkil eden olayda; düzenledikleri çeşitli toplantılarda,

“... Parti, Kürt ve Türk hakları arasındaki tek köprü... Bu düzen Kürt meselesinde iflas etmiştir ve buradan çatır çatır çöküyor. Sorun Kürt halkının iradesine saygı gösterilerek çözülür. Esas çözüm, Kürt halkıdır. Kürtlere ne istiyorsunuz diye soracağız, yok ayrılmak 
isterlerse iradelerine saygı duyacă̆ız, bir referandum yapacağız, Kürt halkına soracağız. Hakkari'den başlayıp, Antep'e kadar herkese soracağız. Bu topraklarda ayrı bir devlet kurmak istiyor musunuz? Evet mi?, Hayır mı? ... Parti iki halkın bir federasyonda birliğini, ortak iktidarını savunacak. ... Parti Türk ve Kürt halkı arasındaki son köprüdür ..... Doğuda özel savaşa son vereceğiz, her iki milleti eşit düzeye getirerek sonunda biçim olarak bir federasyonda çözerek (soruna) son vereceğiz. ... Kürt ve Türk milleti bir halk cumhuriyeti kuracaklar. ... Kürt halkı yıllardır verdiği mücadeleyi ayağa kalkarak göstermeye başladı. Kürt halkı yeni bir devrim yapacak, biji serhildan, biji halkımız. Kürt halkını bu devlet o kadar ezmiş, adını bile silmiş ve yasaklamış; ama yasaklamakla olmuyor. ... Şimdi Fırat'ı bu rejim bir sınır haline getirmiştir. ... Türk milliyetçiliği Fırat'ta boğuldu, geçmez öte tarafa. Çünkü bu topraklarda milliyetçilik olmaz, bu bir Kürt sorunudur. ... Kürt milletine kendi kaderini tayin hakk tanınmalıdır. ... Botan'ın Kürt köylüsü ayağa kalkmış ve kendisinin efendisi olmaya başlamıştır. Ey düzen sen Kürtün adını mı yasakladın, Kürt halkı ayağa kalkiyor. Ezilen Kürt Anayasa yapıyor, kanun yapıyor"

şeklinde açıklamalarda bulunan bir siyasi parti genel başkanının bu açıklamalarının " 3713 sayılı Terörle Mücadele Kanununun 8/1 maddesindeki hangi yöntem, maksat ve düşünce ile olursa olsun TC. Devletinin ülkesi ve milletiyle bölünmez bütünlüğünü hedef alan yazllı ve sözlü propaganda suçunu oluşturduğu," kabul edilmiştir.

Yargitay Ceza Genel Kurulu'nun 20.4.1999 tarihli ve E. 1999/9-58, K. 1999/69 sayılı kararına konu teşkil eden yayın içeriğinde şu açıklamalara yer verilmiştir:

"Sivas coğrafya olarak hürdür. Halkların buluştuğu kavşaktır. Aynı zamanda Batıda doğuya geçiş yollarının kavşağı ve dügü̈m noktasıdır. Coğrafya olarak Sivas dügümünün çözülmesi ile halklar Sivas kavşağında Türkiye Cumhuriyetinden koparak Kürdistan halkı bağımsızlığa Anadolu halkları da demokrasi ve özgürlüğe kavuşacaktır. Anadolu halklarını demokrasi ve özgürlüğe kavuşturma politikası Türkiye Cumhuriyetini bitirme bu coğrafyadan söküp atma politikası ile özdeşleştirilmiştir. Egemen Türklük dışında Ermeni, Arap Türkmen, Laz, Gürcü, Çerkez egemen Türkün egemenliğinden kurtularak demokrasi ve özgürlüğe kavuşacak Anadolu halklarıdır ...

Demokratlar ve devrimciler, bugün, Kürtlerin boyun eğemeye zorlandıkları baskının nedeninin, Cumhuriyetin kendisinde değil, emperyalist politikaların uzantısı olan faşist uygulamalarda ve militer baskıcı politikalarda olduğunu, sorunun çözümünün ise, Türkiye'nin yıkılışında değil, demokratikleşmesinde ve devrimcileşmesinde görülmelidir."

Yargıtay Ceza Genel Kurulu, bu açıklamalarla, sanığın "Türkiye Cumhuriyeti Devletinin, Kürtler, Ermeniler, Araplar, Türkmenler, Alevi Türkler, Lazlar, Çerkezler, Gürcüler gibi halklardan oluştuğuna değinmek suretiyle çeşitli etnik kökene sahip vatandaşları urk temeline dayalı olarak ayrı halklar olarak göstermiş, Türkiye Cumhuriyeti Devleti parçalanıp dağıldığında, yaşayan bu hakların soluk almaya başlayacağını ifade ederek Devletin ülkesi ve Milletiyle bölünmez bütünlügünü bozmayı hedef alan propaganda" suçunu işlediğini kabul etmiştir.

III. Yargıtay 9. Ceza Dairesi, "Türkiye Cumhuriyetinin Kürdistan'da Kürt halkına soyklrım uyguladığı, Türk ulusalcılığının esas alınıp Kürt kimliğinin yasaklanarak bütü̈n ulusal haklarının gasbedildiği, Kürt ulusunun kendi kaderini tayin etmesinin engellendiği, kapsamll şekilde ileri sürülüp, vurgulanarak; Türkiye Cumhuriyeti Devletinin ülkesi ve milletiyle bölünmez bütünlüğünü bozmayı hedef alan propaganda" yapan sanığın "eylemin(in) 3713 sayılı Kanunun 8. maddesi kapsamına giren suçu oluşturduğu" değerlendirmesinde bulunmuştur (Yargıtay 9. Ceza Dairesi, 11.2.1993, E. 1992/11752, K. 1993/664. Ayrica bkz. Yargitay 9. Ceza Dairesi, 18.5.1994, E. 1994/3563, K. 1994/3266); Yargitay 8. Ceza Dairesi, 5.1.1994, E. 1993/11775, K. 1994/5; Yargitay 8. Ceza Dairesi, 1.5.2002, E. 2002/2263, K. 
açıklama özgürlüğünün kapsamında değerlendirilmektedir. ${ }^{28}$ Ancak, başvurulan yöntemin terör olması dolayısıyla, güdülen siyasi amaca rağmen, ortada bir suçluluk olgusu mevcuttur ve bu örgütsel oluşumu, güdülen amaç dikkate alınarak meşru görmek hukuken mümkün değildir ve meşrulaştırma girişiminde asla bulunulmamalıdır.

II. 3713 sayıl1 Kanunun 6. maddesinin ikinci fikrasinda, 7. maddesinin ikinci fıkrasında tanımlanan terör örgütünün propagandası suçu ile yakın ilişkisi bulunan ayrı bir suç tanımına yer verilmiştir:

\section{"Terör örgütlerinin bildiri veya açıklamalarını basanlara veya yayınlayanlara bir yıldan üç yıla kadar hapis cezası verilir.”}

Bu suç tanımı sorunludur. Bu fikrada seçimlik hareketli suç tanımı yapılmıştır. $\mathrm{Bu}$ suçu oluşturan seçimlik hareketlerden biri, "terör örgütünün bildiri veya açıklamalarını" basmak, diğeri ise, bunları yayımlamaktır. Suçun konusu ise, "terör örgütünün bildiri veya açıklamaları"dır. Öncelikle belirtmek gerekir ki, terör örgütünün her açıklamasını yayımlamak, suç oluşturmaz. Örgütün örneğin bir terör saldırısını üstlenme yönündeki açıklamasını yayımlamak, basın (haber verme) özgürlüğ̈̈ çerçevesinde ele alınması gereken bir husustur. Söz konusu suç bakımından önemli olan, terörizmin ve terör örgütünün propagandası mahiyeti taşıyan içerikteki "bildiri veya açıklamalarını"n basılması veya yayımlanmasıdır.

İçeriği propaganda mahiyeti taşıyan "terör örgütünün bildiri veya açıklamalarını" basmak, m. 7, f. 2' de tanımlanan propaganda suçu bakımından bir hazırlık hareketidir. Bu yönü itibarıyla söz konusu suç tanımında bir sorun bulunmamaktadır. Buna karşılık, içeriği propaganda mahiyeti taşıyan "terör örgütünün bildiri veya açıklamalarını" yayımlamak, aynı zamanda m. 7, f. 2'de tanımlanan suçun nitelikli unsurunu oluşturmaktadır. Bu yönü itibarıyla 3713 sayılı Kanunun 6. maddesinin ikinci fikrasındaki suç tanımı ile 7. maddesinin ikinci fıkrasındaki suç tanımı arasında bir mükerrerlik ${ }^{29}$ ve özellikle nitelikli

2002/5625).

28 Bu konuda ayrıntılı tespit ve değerlendirmeler için bkz. Yargıtay CGK, 29.4.2008, E. 2007/8-244, K. 2008/92.

29 “Terör örgütü PKK'nın amacı ve stratejisi doğrultusunda silahlı eylemlerde bulunan ve Halk Savunma Güçleri (HPG) olarak adlandırılan yapılanmanın ana karargah komutanı sıfatıyla konuşan kişinin 'Gabar Dağı kürt halkının gururu, iftiharıdır. Gabar Dağı yiğitlerin yeridir, öyle bir dăg ki Türk Ordusu on binlerce askerini oraya yığmasına rağmen hükmedemiyor, her gün ağır kayıplar veriyor. Gabar'da eylem yapan grubumuzu selamlyyoruz. Tüm Kürdistan dăgları, Ağrı'dan Munzur'a, Siser'e, Andok'a kadar hepsi halkımızın 
unsur bakımından çelişki ${ }^{30}$ bulunmaktadır. ${ }^{31}$

Aslında bu çelişkili durum, Alman Ceza Kanununda da mevcuttur.

Avrupa Birliği Konseyinin 13.06.2002 tarihli ve $\mathbf{2 0 0 2 / 4 7 5 / J I ~ s a y 1 1 ~}$ Terörizmle Mücadele Çerçeve Karari ${ }^{32}$ ile üye devletler arasında terör suçlarının diğer suçlarla ilişkisine, terör örgütüne, terör suçlarından dolayı sorumluluğa ve bu suçlara ilişkin soruşturma ve kovuşturma usullerine ilişkin kanuni düzenlemelerde yeknesaklığı sağlamak amaçlanmıştır. Bu karar doğrultusunda Alman Ceza Kanununda yapılan 22.8.2002 tarihli değişiklikle ${ }^{33}$ Kanunun terör örgütüne ilişkin hükümlerinin yabanc1 terör örgütleriyle ilgili olarak da uygulanmasını sağlamak amacıyla Kanuna § 129b eklenmiştir. Keza Alman Ceza Kanununda yapılan 22.12.2003 tarihli değişiklikle ${ }^{34}$ Avrupa Birliği Konseyinin söz konusu 2002/475/JI sayılı Çerçeve Kararı hükümleri dikkate alınarak Alman Ceza Kanununun terör örgütü ile ilgili hükümlerine ilişkin $§ 129$ a yeniden düzenlenmiştir. ${ }^{35}$

umudunun yükseldiği yerlerdir.', 'Bahardan beri binlerce askerin bulunduğu taburların konuşlandığı bir yerde bu eylem oldu. Bu eylem bir kez daha gösterdi ki Türk Devletinin yaptığı propagandanın hepsi yalan, gerilla güçleri ne zaman nasıl ve hangi koşullarda olursa olsun Türk Ordusuna darbe vurabilir. Bu eylem askeri anlamda bunu gösterdi.' biçimindeki açıklamalarının açıklamayı yapan kişinin ideolojik ve örgütsel konumu da dikkate alındığında PKK terör örgütünün amaçları doğrultusunda kullandığı şiddeti, silahlı çatışmayı özendirici ve teşvik edici nitelikte olduğu, bu açıklamalara ana karargah komutanı olarak adlandırılan kişinin fotoğrafı ile birlikte ulusal çapta yayın yapan bir gazetede yer verilmesinin 3713 sayılı Kanunun 6/2. maddesinde düzenlenen terör örgütü açıklamasını yayınlamak suçunu oluşturacağı anlaşılm"1ştır: Yargıtay 9. CD, 3.1.2012, E. 2010/1679, K. 2012/140. Ayrıca bkz. ÖZBEK, Terör Örgütünün Propagandası Suçu, sh. 93 vd.

30 Bkz. Yargitay 9. CD, 10.6.2014, E. 2013/14755, K. 2014/7125; Yargitay 9. CD, 23.9.2008, E. $2008 / 5842$, K. $2008 / 10214$.

312006 yılında görev yaptığım 5532 sayılı Kanunun hazırlık çalışmaları sürecinde $3713 \mathrm{~s}$. Kanunun 6. maddesinin ikinci fikrasının bu mülahazalarla yürürlükten kaldırılması yönünde yoğun çaba göstermiş olmama rağmen, bu çabalarımda başarılı olamadım. Bkz. ÖZGENÇ, İzzet: Terörle Mücadele Kanunu, Ankara, Eylül 2006, sh. 43 vd.; YILDIRIM, Terör Örgütünün Propagandası Suçu, 2. bası, sh. 249.

32 Official Journal of the European Union / Amtsblatt der Europāischen Union, 22.6.2002, L 164/3.

33 “34. Strafrechtsänderungsgesetz”: BGB1 I, 2002, sh. 3390. Ayrıca bkz. Deutscher Bundestag - 14. Wahlperiode - Drucksache14/7025, Gesetzentwurf, 04.10.2001; Deutscher Bundestag - 14. Wahlperiode - Drucksache 14/8893, Beschlussempfehlung und Bericht des Rechtsausschusses (6. Ausschuss), 24.04.2002.

34 BGB1 I, 2003, sh. 2836. Ayrica bkz. Deutscher Bundestag - 15. Wahlperiode - Drucksache 15/813, Gesetzentwurf, 08.04.2003; Deutscher Bundestag - 15. Wahlperiode - Drucksache 15/1730, Beschluss und Bericht des Rechtsausschusses (6. Ausschuss), 15.10.2003.

35 Ayrıntılı bilgi için bkz. Terörizm Suçlarıyla İlgili Karşılaştırmalı Çalışma Raporu, 
Bu değişiklikle, Alman Ceza Kanununda, terör örgütünün desteklenmesi suçunun ( $\S 129$ a, f. 5, birinci cümle) yanı sıra, terör örgütüne üye veya destekçi temini çabasında bulunma suçu tanımlanmıştır (Alman CK, § 129a, f. 5, ikinci cümle; ayrıca bkz. § 129, f. 1, ikinci cümle). Bu itibarla, terör örgütüne üye veya destekçi teminine çabalamak, gayret etmek ("werben") fiili, suç oluşturmaktadır. Bu düzenlemeye göre, terör örgütüne veya örgütün ideolojisine sempati duyulmasına yönelik açıklamalar, artık suç oluşturmamaktadır. ${ }^{36} \mathrm{Bu}$ suçun oluşabilmesi için, örgüte üye olmayan bir kişiyi örgütle organik bağlantı kurmaya doğrudan teşvik etmek ve bu suretle, örgütün faaliyeti çerçevesinde planlanan suçların işlenmesini kolaylaştırmak, örgütün faaliyet ve hedefine ulaşma kabiliyetine pozitif bir katkı sağlamak, örgütün tehlikeliliğini tahkim etmek gerekir. ${ }^{37}$

Fakat belirtmek gerekir ki, 3713 s. K, m. 7, f. 2, son cümle düzenlemesine benzer hükümler de Alman CK, $\S 86$ ve $\S 86$ ' da yer almaktadır. Bu hükümlere göre, yasaklanmış olan bir örgütün propaganda araçlarını, tanıtım işaretlerini üretmek, bulundurmak, dağıtmak, kamuya açık olarak gösterime sunmak suç oluşturmaktadır. ${ }^{38}$ Dikkat edilmelidir ki, bu suçun oluşabilmesi için söz konusu propaganda araçlarının içeriğinin herhangi bir somut suçla ilgisinin olmasına gerek bulunmamaktadır. ${ }^{39}$

III. 3713 s. Kanunun 7. maddesinin ikinci fikrasında 11.4.2013 tarihli ve 6459 sayılı Kanunla (m. 8) değişiklik yapılarak, fikra metninin birinci cümlesi,

"Terör örgütünün; cebir, şiddet veya tehdit içeren yöntemlerini meşru gösterecek veya övecek ya da bu yöntemlere başvurmayı teşvik edecek şekilde propagandasını yapan kişi, bir yıldan beş yıla kadar hapis cezası ile cezalandırılır"

şeklinde yeniden düzenlenmiştir. $\mathrm{Bu}$ düzenlemeye paralel olarak $3713 \mathrm{~s}$.

25.03.2019, Ankara Hacı Bayram Veli Üniversitesi Türk Ceza Hukuku Uygulama ve Araştırma Merkezi (TÜRK-CE-MER) yayını, sh. 3 vd.

36 Münchener Kommentar zum StGB (Schäfer), § 129, kn. 96.

37 BGH, Urteil vom 2.4. 2015, 3 StR 197/14, kn. 13, 14; BGH, Urteil vom 14.8.2009, 3 StR 552/08, kn. 138-141.

38 Ayrıntılı bilgi için bkz. Terörizm Suçlarıyla İlgili Karşılaştırmalı Çalışma Raporu, 25.03.2019, Ankara Hacı Bayram Veli Üniversitesi Türk Ceza Hukuku Uygulama ve Araştırma Merkezi (TÜRK/CE-MER) yayını (Editörler: Prof. Dr. İzzet Özgenç, Prof. Dr. Cumhur Şahin, Prof. Dr. İlhan Üzülmez), Ankara, 2019, sh. 3 vd.

39 BGH, Urteil vom 31.7. 2002, 3 StR 495/1, kn. 16 vd. 
Kanunun 6. maddesinin ikinci fikrasında da değişiklik yapılmıştır. Buna göre;

"Terör örgütlerinin; cebir, şiddet veya tehdit içeren yöntemlerini meşru gösteren veya öven ya da bu yöntemlere başvurmayı teşvik eden bildiri veya açıklamalarını basanlar veya yayınlayanlar bir yıldan ü̧̈ yıla kadar hapis cezası ile cezalandirılır."

$\mathrm{Bu}$ düzenlemeye göre, terör örgütünün, faaliyeti çerçevesinde işlenen cebir, şiddet veya tehdit içeren fillerden ve genel olarak suçlardan bahsetmeksizin, güttüğü siyasi, sosyal ve ekonomik amaçların müzakere edilmesi bağlamında Devlet tarafından muhatap alınması gerektiğini savunmak, bu yönde yayın yapmak suç oluşturmayacaktır.

Bu düzenleme ile, PKK'nin bir terör örgütü olmaktan çıkarılıp, güttüğü siyasi, sosyal ve ekonomik amaçlar itibarıyla Devlet tarafindan muhatap alınmasının ve süreç içinde "meşruiyeti" konusunda izlenim oluşturulmaya çalışılan “taraf" statüsüne kavuşturulmasının yolu açılmış olmaktadır.

Ancak bu düzenlemede, terör örgütünün propagandası suçunun tanımlandığ1 7. maddenin ikinci fikrasının birinci cümlesi ile sonuncu cümlesi arasında bilinçli olarak bir çelişki oluşturulmuştur. Zira 6459 sayılı Kanuna ilişkin Hükümet Tasarısının müzakereleri sırasında bu çelişkili durumla ilgili olarak tarafımdan ilgili siyasiler bilgilendirilmiş olmasına rağmen, kayıtsız kalınarak Tasarı metninin kanunlaşması sağlanmıştır. Bu çelişkili düzenleme karşısında, "cebir, şiddet veya tehdit içeren yöntemlerini meşru gösterecek veya övecek ya da bu yöntemlere başvurmayı teşvik edecek" herhangi bir ifade kullanılmasa bile, örneğin terör örgütü lehine slogan atılması, terör örgütüne ait amblem, resim veya işaretlerin teşhir edilmesi suç olmaya devam etmektedir. ${ }^{40}$

Öncelikle belirtmek gerekir ki, doğru olmadığı izahtan vareste olan bu değişiklik, malum "çözüm süreci"nin bir "gereği" olarak yapılmıştır. Bu süreçte, malum terör örgütünün faaliyeti çerçevesinde işlenen pek çok suç olgusu Devlet güçleri tarafindan görmezlikten gelinmiş ve terör örgütünün palazlanması sağlanmıştır. PKK terörünü sonlandırmak amacıyla başlatılan malum “çözü̈m süreci"nde çıkarılan 10.7.2014 tarihli ve 6551 sayıl1 "Terörün Sona Erdirilmesi ve Toplumsal Bütünleşmenin Güçlendirilmesine Dair

40 Ayrıca belirtmek gerekir ki, 3713 s. K, m. 7, f. 3'de tanımlanan fiillerin, terör örgütünün propagandası suçu ile ilişkilendirilmesi doğru olmamıştır. Örneğin düzenlenen bir toplantı ve gösteri yürüyüşüne kişinin kimliği tespit edilemeyecek şekilde yüzünü kapatarak katılmas1nın, 2911 sayılı Kanunda toplantı ve gösteri yürüyüşü düzeni ile ilgili bir suç veya kabahat olarak tanımlanması gerekirdi. 
Kanun'la Hükûmete;

“a) Terörün sona erdirilmesi ve toplumsal bütünleşmenin güçlendirilmesine yönelik siyasi, hukuki, sosyoekonomik, psikolojik, kültür, insan hakları, güvenlik ve silahsızlandırma alanlarında ve bunlarla bağlantılı konularda atılabilecek adımları belirle(mek;)

b) Gerekli görülmesi hâlinde, yurt içindeki ve yurt dişındaki kişi, kurum ve kuruluşlarla temas, diyalog, görüşme ve benzeri çalışmalar yapılmasına karar ver(mek) ve bu çalışmaları gerçekleştirecek kişi, kurum veya kuruluşları görevlendir(mek;)

c) Silah bırakan örgüt mensuplarının eve dönüşleri ile sosyal yaşama katılım ve uyumlarının temini için gerekli tedbirleri al(mak)"

hususlarında yetki verilmiştir (m. 2, f. 1). Yine söz konusu Kanunun 4. maddesinde, bu çerçevede verilen "görevleri yerine getiren kişilerin bu görevleri nedeniyle hukuki, idari veya cezai sorumluluğu doğmaz" hükmüne yer verilmiştir (f. 2).

Buna göre, malum “çözüm süreci”nde, giydikleri üniforma görüntüsü arz eden kıyafetler ve hatta üzerlerinde taşıdıkları silahlar itibarıyla PKK terör örgütünün mensubu oldukları açıkça anlaşılan kişilerin, yurt dişına çıkmakta oldukları gerekçesiyle yakalanmaması yönünde talimat veren ve bu talimata uyarak, suçüstü haline rağmen, bu kişileri yakalamaktan sarfinazar eden kamu görevlileri ceza hukuku bakımından sorumlu tutulamayacaklardır!

Amaç itibarıyla olmasa bile, izlenen yöntem itibarıyla hukuka aykırı olan bu sürecin oluşturduğu siyasi atmosferde PKK terör örgütünün faaliyeti çerçevesinde düzenlenen hukuka aykırı toplantı ve gösteri yürüyüşleri sırasında taşınan pankartlar ve atılan sloganlar içerikleri itibarıyla suç oluşturmasına rağmen, mülki amirler ve kolluk görevlileri tarafindan bu toplantı ve gösteri yürüyüşlerine katılanlar gerektiğinde zor kullanılarak dağıtılmamıştır.

Ancak, malum çözüm sürecinde palazlanan terör örgütünün 2015 y1lında başlattığı silahlı başkaldırı hareketi ve bu başkaldırının bastırılması amacına yönelik olarak güvenlik güçleri tarafından gerçekleştirilen operasyonlar sonrasında, terörizmin ve terör örgütünün propagandası mahiyeti taşıyan toplantı ve gösteri yürüyüşlerine karşı müsamahadan tamamen vazgeçilmiş ve Terörle Mücadele Kanunu, m. 7, f. 2’de 6459 sayılı Kanunla yapılan söz konusu değişiklik, terör örgütünün propagandası suçu bakımından dikkate alınmamaya başlanmıştır. 
IV. Aşağıda inceleme konusu yapmış bulunduğumuz Yargıtay Ceza Genel Kurulu kararları ile Anayasa Mahkemesinin bireysel başvuru kararları, malum "çözüm süreci"nde işlenen terörizmin ve terör örgütünün propagandas1 filleriyle ilgilidir.

Birinci Karar: Yargitay Ceza Genel Kurulu'nun, 6.2.2020 tarihli ve E. 2016/729, K. 2020/67 sayılı Kararına konu teşkil eden olayda; Türkiye'de hukuki varlığı devam eden ve faaliyette bulunan bir siyasi partinin ilçe teşkilatı tarafından organize edilen yerel seçim etkinlikleri çerçevesinde düzenlenmiş olan 28.3.2014 tarihli açık hava toplantısına "devrim şehitleri"ne bir dakikalık saygı duruşu ile başlanır ve toplantı sırasında, "şehit namırın", "biji serok Apo", "dişe diş kana kan seninleyiz Öcalan", "jin jiyan azadi" ve "faşizme karşı отиz отиza" ş̧eklinde sloganlar atılır; Abdullah Öcalan'ın posteri ve PKK'nin Suriye kanadı olan PYD'nin silahlı gücü YPG'nin (Yekiyenen Parastina Gel) flaması açılır.

Yargıtay Ceza Genel Kurulu, bu olayda, aşağıdaki gerekçe ile, terör örgütünün propagandası suçunun oluştuğunu oyçokluğuyla kabul etmiştir:

“3713 sayılı Kanun'un 7. maddesinin 2. fikrasındaki suçun oluşabilmesi için eylemin terör örgütünün; cebir, şiddet veya tehdit içeren yöntemlerini meşru gösterecek veya övecek ya da bu yöntemlere başvurmayı teşvik edecek şekilde gerçekleştirilmesi gerektiği ifade edilmiş olup fikranın son cümlesinde "Aşağıdaki fiil ve davranışlar da bu fikra hükümlerine göre cezalandırılır" şeklindeki düzenlemeyle; toplantı ve gösteri yürüyüşü sırasında gerçekleşmese dahi, terör örgütünün üyesi veya destekçisi olduğunu belli edecek şekilde; örgüte ait amblem, resim veya işaretlerin asılması ya da taşınması, slogan atılması, ses cihazları ile yayın yapılması, terör örgütüne ait amblem, resim veya işaretlerin üzerinde bulunduğu üniformanın giyilmesi de bu fıkranın (b) bendinde maddeler hâlinde belirtilmiş olup yasa koyucu bu bentteki eylemleri gerçekleştiren sanığın cezalandırılabilmesi açısından Kanun'un 7. maddesinin 2. fıkrasında belirtilen unsurları aramamış yalnızca ceza atfi amacıyla bir düzenleme yapmıştır.

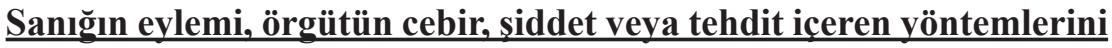
messu gösterecek veva övecek ya da tesvik edecek nitelikte olmamakla birlikte Kanunda yer almayan bir gerekçeyle unsur olarak aranamayacağı ve sanığın eyleminin hukuka uygun kabul edilmesinin toplum açısından meydana getireceği yakın tehlike 
de gözetildiğinde, sanığın PKK silahlı terör örgütüne ait bayrağı taşınmaktan ibaret eyleminin silahlı terör örgütünün propagandasını yapma suçunu olușturduğu kabul edilmelidir”.

Yargıtay Ceza Genel Kurulu Başkanı, aşağıdaki gerekçe ile bu karara katılmamıştır:

“Avrupa İnsan Hakları Mahkemesi, şiddeti teşvik ve tahrik edici nitelikte olmayan silahlı terör örgütüyle ilgili propagandayı istikrarlı bir şekilde ifade özgürlüğü kapsamında değerlendirilmesi üzerine bu kararlara uyum sağlama amacıyla 3713 sayılı Yasa'nın 7. maddesinin ikinci fikrasında yapılan değişiklik ile her türlü terör örgütü propaganda suçuna; terör örgütünün cebir, şiddet veya tehdit içeren yöntemlerini meşru göstermek veya övmek ya da teşvik etmek unsurunu ilave etmiştir. Aynı fikranın son cümlesinde "Aşağıdaki fiil ve davranışlarda bu fikra hükmüne göre cezalandirllır" şeklinde yapılan atıfla $\mathrm{b}$ bendinde sayılan fiil ve davranışlara hem ceza hem de unsur atfinda bulunulmuştur. Diğer bir ifadeyle silahlı terör örgütünün propagandasını yapma suçundan cezalandırılabilmek için $b$ bendinde belirtilen eylemlerin aynı zamanda örgütün cebir, şiddet veya tehdit içeren yöntemlerini meşru göstermesi veya övmesi ya da teşvik etmesi gerekir. Sözü edilen bu unsurları aramamak yasa değişikliğinin amacına da aykırıdır. Sözü edilen (b) fikrasında sayılan fiillerde şiddeti meşru gösterme, övme veya teşvik etme özelliklerini aramadığımız takdirde Avrupa İnsan Hakları Mahkemesince sözleşme kapsamında ifade özgürlüğü içerisinde değerlendirilen bir eylemi cezalandırmış oluruz. Bu da suçun genel unsurları içerisinde yer alan hukuka aykırılık unsurunu göz ardı etmek, kullanılan bir hakkı suç sayıp cezalandırmak demektir.

Somut olayda sanığın PKK silahlı terör örgütüne ait bayrağı açmaktan ibaret eylemi her ne kadar 3713 sayılı Kanun'un 7 maddesinin ikinci fikrasının (b) başlığının 1. alt bendi kapsamında 'örgüte ait amblem, resim veya işaretlerin asılması ya da taşınması' kapsamında kabul edilse de Kanun'un 7. maddesinin 2. fikrasında belirtilen terör örgütünün cebir, şiddet veya tehdit içeren yöntemlerini meşru gösterecek veya övecek ya da bu yöntemlere başvurmayı teşvik edecek nitelikte bulunmadığından silahlı terör örgütünün propagandasını yapma suçunun unsurları itibarıyla oluşmadığ 1 kanaatinde"yim.

İkinci Karar: Yargitay Ceza Genel Kurulu'nun 18.2.2020 tarihli ve E. 
2016/1140, K. 2020/110 sayılı Kararına konu teşkil eden olayda; yapılan çağrılar üzerine 1.9.2012 tarihinde gerçekleştirilen toplantı ve gösteri yürüyüşünün yapıldığı alanda kurulu bulunan platformun çevresinde açıkça görünebilirliği sağlanacak büyüklükte "Bir Eylül Onurlu Bir B. İçin Demokratik Çözüm ve Müzakere", “Askeri ve Siyasi Operasyonlar Durdurulsun" ibareli pankartlar asılır; meydanda toplanan grup tarafindan Abdullah Öcalan'ın posterleri açı1ır; PKK'nin sembolü olan işaretleri taşıyan pankartlar taşınır; "Biji Serok Apo" (Yaşasın Başkan Apo), "Canımızla Kanımızla Seninleyiz Ey Başkan" şeklinde Abdullah Öcalan'1 öven, Abdullah Öcalan'a bağl1lı̆̆ ifade eden sloganlar atılır; terör örgütünü övücü mahiyette sloganlar atılır ve marşlar söylenir.

Yargitay Ceza Genel Kurulu, bu olayda, yukarıda iktibas edilen birinci Karardaki gerekçe ile, terör örgütünün propagandası suçunun oluştuğunu oyçokluğuyla kabul etmiştir. ${ }^{41}$

${ }^{41}$ Aynı yönde diğer bir karar için bkz. Yargıtay CGK, 18.2.2020, E. 2017/384, K. 2020/111.

Yargitay Ceza Genel Kurulu'nun 18.6.2020 tarihli ve E. 2017/600, K. 2020/306 say1l Kararına konu teşkil eden olayda; Adana Ağır Ceza Mahkemesinde görülmekte olan davanın duruşmasında, haklarında terör örgütü üyeliği ve sair suçlardan dolayı verilen mahkumiyet hükmünün açıklanması üzerine, bütün sanıklar duruşma salonunda "Biji serok Apo" şeklinde slogan atarlar.

Yargitay Ceza Genel Kurulu bu "olayda, duruşma salonunda, sanıkların topluluğa hitaben "Biji serok Apo" şeklinde söyledikleri sözlerin her ne kadar 3713 say1lı Kanun'un 7 maddesinin ikinci fikrasının (b) başlığının 2. alt bendi kapsamında "terör örgütünün üyesi veya destekçisi olduğunu belli edecek şekilde slogan atılması" şeklinde kabul edilse de ifadenin gerek içeriği gerekse açıklandığı ortam gözetildiğinde; ifade özgürlüğü kapsamında değerlendirerek sanıklara atılı silahlı terör örgütünün propagandasını yapma suçunun unsurları itibarıyla oluşmadığı” yönünde içtihatta bulunmuştur.

Belirtmek gerekir ki, karara konu teşkil eden olayda, kişiler terör örgütü üyeliğinden ve sair suçlardan dolayı haklarında verilen mahkumiyet hükmünün açıklandığı sırada, bir tepki olarak, bu sloganı atmışlardır. Atılan bu sloganla kişiler, haklarında verilen mahkumiyet hükmünün açıklanmasına rağmen, işledikleri suçlardan dolayı pişmanlık duymadıklarını ve terör örgütüne bağlllıklarının devam ettiğini beyan etmişlerdir. Bu karar, sonuç itibarıyla doğrudur. Ancak, gerekçesi itibarıyla tutarsızdır. Yukarıda da belirttiğimiz gibi, terörizmin ve terör örgütünün propagandası suçu, bir amaç suçtur, yani muhatabı etkilemek, terör örgütünün ve faaliyetlerinin "meşruiyeti" ve "ulviyeti" konusunda muhatap nezdinde bir kanaat oluşturmak amacıyla işılenir. Oysa, kişiler sanık olarak yargılanmakta oldukları mahkeme salonunda "Biji serok Apo" şeklinde slogan atarken, haklarında verilmiş olan mahkumiyet hükmüne tepki gösterdiklerini, işledikleri suçtan dolayı pişmanlık duymadıklarını beyan etmiş olmaktadırlar. Sanıklar bakımından bu tür fiillerin münhasıran duruşma disiplininin bozulması çerçevesinde ele alınıp değerlendirilmesi gerekir. Kararda, "ifadelerin açıklandığ ortam"dan bahisle propaganda suçunun oluşmadığı yönündeki gerekçe, tutarsızlıkla maluldür (Aynı yöndeki gerekçe için ayrıca bkz. Yargıtay CGK, 23.6.2020, E. 2017/943, K. 2020/311). Bir başka kararda da "devletin birliğini ve ülkenin bütünlügünü bozmak suçundan" dolayı haklarında kurulan mahkumiyet hükmüne tepki olarak sanıkların "Biji serok 
Üçüncü Karar: Yargıtay Ceza Genel Kurulu'nun 11.6.2020 tarihli ve E. 2016/1159, K. 2020/280 sayılı Kararına konu teşkil eden olayda; Abdullah Öcalan'ın Kenya'da yakalanarak Türkiye'ye getirilmesinin yıl dönümü münasebetiyle 15.2.2012 tarihinde düzenlenen ve aralarında milletvekillerinin, belediye başkanlarının ve belediye meclisi üyelerinin bulunduğu izinsiz toplantıda katılımcilar tarafindan, "Be serok jiyan nabe, PKK halktı halk burada, Kürdistan faşizme mezar olacak, T.C. şaşırma bizi dağa taşırma, T.C.'nin piçleri yıldıramaz bizleri, Bulanık ovası Apocular yuvası, vur gerilla vur Kürdistanı kur, baskılar bizi yıldıramaz, gençlik Aponun fedaisidir, geliyor geliyor apocular geliyor, AKP'yi basarız Erdoğan'ı asarı, disa disa serhildan serok'ime öcalan, em kine apo cine" şeklinde sloganlar atılır; sarı zemin üzerine yeşil-kırmızı yazı ile yazıl1 "Ya onurlu bir çözüm ya da görkemli bir direniş", siyah bez üzerine beyaz renk yazı ile; "15 Şubat Uluslararası Soykırım Gününü şiddetle kınıyoruz", beyaz, kırmız1, sarı, yeşil ve mor zemin üzerine kırmız1-siyah renk yazı ile "Ji bo jiyanek bi rumet an azadi an azadi" şeklinde pankartlar taşınır. Keza bu toplantıda, belediye meclisi üyesi olan S tarafindan,

"Bilgi sahibi olmadığımız ancak tarihi araştırmalar sonucunda farklı halkların yaşadı̆̆ bir gerçektir. Bu halklar kendi dönemin egemenleri tarafindan soykırıma uğratılmış ve yok edilmişlerdir. 15 Şubat 1923 Lozan Antlaşması bir savaş sürecinin bitirilmesiyle dönemin egemen devletlerarasıbiranlaşmayla sonuçlanantüm hazırlıklarıncoğrafyamızda oluşacak bir yapılanma Kürtler, Türkler ve diğer halkların varlığ dikkate alınarak planlanmıştır. Lozan'a giden Türk temsilcileri devre dışı bırakılarak bölgemizde sağlanacak bir barışın önüne geçmişlerdir. 15 Şubat 1925 Şeyh Sait isyanı ile bu Cumhuriyet Kürtlerin ve Türklerin Cumhuriyetidir sözü yerine getirilmediği için önce isyanlar sonrası katliamlar başlamıştır. Birkaç örnek vermek gerekirse Dersim, A ̆grl, Zilan, Koçgir ve daha niceleri 15 Şubat 1999 tarihinde Kürt halk önderi sayın Öcalan'ın uluslararası bir komployla esir alınması ve bugüne kadar Kürtlere uygulanan katliamların devamında çıkar să̆layan emperyalistlerin planlamasıdır. Onun içindir ki bunu herkes uluslararası bir komplo olarak görür. Bugünkü Orta Doğuda var olan çıkar savaşları

apo" șeklinde slogan atması fiilinin, "olayın meydana geldiği yer ve muhatap kitle de" dikkate alınarak propaganda suçunu oluşmadığı değerlendirmesinde bulunulmuştur: Yargıtay 16. CD, 29.9.2016, E. 2016/1297, K. 2016/4872. Ayrica bkz. Yargitay 16. CD, 19.12.2016, E. 2016/3839, K. 2016/7571; Yargitay 16. CD, 28.2.2017, E. 2017/304, K. 2017/937; Yarg1tay 16. CD, 15.6.2017, E. 2017/1334, K. 2017/4470. 
apaçık ortadadır. Orta Doğudaki tehlikeli gidişatları bilen Öcalan Orta Doğu için antiemperyalist demokratik Orta Doğu Halklar Federasyonu oluşturmasının bir zorunluluk olduğunu defalarca belirtmesi gerek bölgemizde gerekse Orta Doğuda ... ...Bu çözümlülüğ̈̈ bölge halklarına fayda sağlayamadı̆̆ gibi dünyada da fayda sağlayamayacaktır. Kürt sorununun çözümünün tek muhatabı PKK ve O'nun önderliğidir. 15 Şubat 1999 uluslararası komploda yer alan tüm devletleri kınıyor karşı duruтитиzu tüm halkımıza beyan ediyoruz"

şeklindeki bildiri metni okunur.

Yargıtay Ceza Genel Kurulu, gösteri yürüyüşüne katılan ve toplantıda bu bildiriyi alenen okuyan belediye meclisi üyesi S'nin fiilinin terör örgütünün propagandası suçunu oluşturmadığına karar vermiştir.

Dördüncü Karar: Anayasa Mahkemesinin 3.10.2019 tarihli ve 2018/38143 Bireysel Başvuru sayılı kararına ${ }^{42}$ konu teşkil eden olayda; X, bir siyasi parti il teşkilatının 17.3.2013 tarihinde düzenlediği açık hava toplantısında, aşağıdaki içerikte bir konuşma yapar:

"Merhaba. Çewane (nasılsınız) halkım hoş geldiniz. Nevroz piroz be (nevruzunuz kutlu olsun). Size Kürt halk önderi sayın Öcalan'ın selamını getirdim. Bu soğuk havada güneş gibi içimizi ısıtsın diye sayın Öcalan'ın selam gönderdiği siz evlatlarımızın kardeşlerimizin selamını getirdim. Selam olsun.

Halkların Demokratik Kongresi adına burayı dolduran bugüne kadar bütün mücadele alanlarında olduğu gibi bu alanı da dolduran, bütün temsiliyetlere, bütün HDK bileşenlerine, halkların temsilcilerine selam olsun. Hoşgeldiniz, Newrozunuz kutlu olsun. Barışa vesile olsun.

Yoldaşlar, yeni bir sürece başlıyoruz. Bu, adına barış masası diyorlar, ama masada kotarılan bir şey değildir. Bu yeryüzüne ve gökyüzüne bütün Türkiye halklarının, başta Kürt halkı olmak üzere, Ermenilerin, Süryanilerin, Kafkas halklarını, Çerkezlerin mücadelesi ile yeryüzüne ve gökyüzüne yazlldı bu, masalarda kotarılmadl. Bu barış, başta Kürt halkı olmak üzere emekçiler, mazlumlar olmak üzer hepinizin eseridir. Barışınız da kutlu olsun.

Biz de HDK olarak Kürdistan'da onun onurlu evlatlartyla onur

\footnotetext{
42 “Sırrı Süreyya Önder Başvurusu”, RG: 8 Ekim 2019/30902.
} 
duyuyoruz.

Yoldaşlar, çok değil, bundan 1 sene önce yine bu alanlardaydik, yine elimizde ve kalbimizde barış iradesi ile gelmiştik, bu alana sokulmadık. $O$ gün de barış diyorduk, bugün de barış diyoruz, yarın da barış diyeceğiz. İste halkların iradesi, işte yan yana durmanın erdemi ve kararlılığının eseri budur. Ne oldu, geçen yıl bu meydana almadılar, giremedik mi, girdik. Iş̧te barış masaların değil, bu inadın bu iradenin sonucudur. Onun için barış size kutlu olsun, onun için bize kutlu olsun.

Biz, biz bir mücadelenin sonuna gelmedik, bir mücadele bitmiş değil. Biz bir mücadelenin en acı bölümünün sonuna geldik, en yakıcı bölümünün, ölümlü kanlı bölümünün sonuna geldik. Bundan sonrast artı yeni Türkiye'yi bütün halklarla birlikte inşa etmenin zamanıdır. Tam bir demokrasi ile emekçisi ile ezilenleri ile mazlumlarıyla bu mücadelemiz ta ki tüm halkların, tüm ezilenlerin kurtuluşuna kadar devam edecek. Ama, artık bu hikayenin, ki anlatılan bizim hikayemizdir, sizin hikayenizdir. Acıklı bölümün acılı bölümün sonuna geldik. Peki ne pahasına? Bu halk, siz bizi öldürmekten yorulacă̆ınız güne kadar direneceğiz dedi, biz yorulmayacă̆ız, biz direneceğiz dedi. İşte sonucu bu.

Biz, siz bizi kabristanla mı korkutuyorsunuz? Biz o kabristanı gülistan ederiz dedi, ölerek bu barışı getirdi. Siz, bizi zindanlarla mı korkutuyorsunuz; biz o zindanları bir mücadele alanı, bir Newroz alanı, 1 Mayıs alanı yaparı, yine getiririz dedi. Iş̧te bu barış onun eseridir. Onun için de kıymetini en çok bizler bileceğiz, en çok sizler bileceksiniz, bütün Türkiye halklarl bilecek. Bütün ezilenler bilecek. Dolayısiyla, bu barış iradesini, güvercin kasaplarının eline boğdurtmayacă̆ı, boğdurtmayacă̆ız, boğdurtmayacă̆ız.

Sayın Öcalan, hepinize iletilmek üzere dedi ki; ne eskisi gibi savaşacă̆ız, ne eskisi gibi yaşayacă̆ı. Bütün halklar, Türkiye halkları özgürleşene kadar, tam demokratik bir ortamda yaşayana kadar da mücadelemiz, barış azmimiz ve irademiz devam edecek dedi. Biz de bu iradeyi HDK olarak bu iradeyi güçlendireceğiz, bu iradenin yanında olacă̆ız, bugüne kadar nasıl bu mücadelenin kavgasını verdiysek, bundan sonra da barış iradesini yere düşürmemek için bundan sonra da ne gerekiyorsa hep birlikte yan yana, omuz omuza yapacă̆lz. Bu irademizi bir kez daha sizinle birlikte haykırmak istiyorum.

'Biji bıratiya gelan, yaşasın halkların kardeşliği, yaşasın barış.' 
Yoldaşlar, genel başkanımız (Y de) burada. Ben HDK adına hepinizi tekrar selamliyorum. Esas konuşmayı sayın eş genel başkanımız yapacak. Ben sadece, hem HDK adına hem sayın Öcalan'ın ve onun yoldaşlarının selamın iletmek üzere çıtım.

Hep birlikte haykıralım; An serkeftin an serkeftin. An azadi an azadi. Yaşasin barış, Newroz piroz be! Hepinizi sayglyla sevgiyle selamllyorum. Hoşçakalın doştça kalın."

$\mathrm{Bu}$ konuşması dolayısıyla $\mathrm{X}$ hakkında kamu davası açı1ır.

Yapılan yargılama sonucunda $\mathrm{X}$ aşağıdaki gerekçe ile terör örgütünün propagandası suçunu işlediği kabul edilerek, 3713 s. Kanun, m. 7, f. 2 hükümlerine istinaden 3 yıl 6 ay hapis cezasına mahkum edilir.

“3713 sayılı Yasanın 6459 sayıl Yasayla değişik 7/2 maddesinde terör örgütünün cebir, şiddet veya tehdit içeren yöntemlerini meşru gösterecek veya övecek ya da bu yöntemlere başvurmayı teşvik edecek şekilde propagandasın yapan kişinin cezalandırılacă̆ı düzenlenmiştir. AIHM'nin fikir hürriyeti konusunda sözleşmenin 10. maddesiyle ilgili verdiği kararlar da bu maddeyle ayn yöndedir. Bu madde ile bilinmesi gereken önemli bir husus, propaganda kabul edilen eylemin bizzat kendisinin şiddet içerikli olması, nefret, cebir ya da tehdit içermesi gerekmediğidir. Propaganda olan eylemin kendisi şiddet, nefret, tehdit veya cebir içerikli olması ve terör örgütünün cebir, şiddet veya tehdit içeren yöntemlerini meşru gösterecek veya övecek ya da bu yöntemlere başvurmayı teşvik edecek şekilde olması halinde bu madde gereğince suç oluşur... Kaldı ki, terör örgütünün şiddet içerikli eylemlerini öven, meşru gösteren veya teşvik eden eylemler bu haliyle zaten şiddeti teşvik eder hale gelir. Örneğin, 'PKK'nın yapmış olduğu eylemleri destekliyoruz.' şeklinde atılan bir sloganda kullantlan kelimelerin hiçbiri şiddeti çağrıştırmamaktadır. Ancak cümle bir bütün halinde değerlendirildiğinde bölücü terör örgütü PKK'nın eylemlerinin desteklendiği ve şiddeti övücü nitelikte olduğu sonucuna varılmalıdır. Dolayıstyla bu suç için önemli olan propaganda teşkil eden eylemin, terör örgütünün cebir, şiddet veya tehdit içeren yöntemlerini meşru göstermesi veya övmesi ya da bu yöntemlere başvurmayı teşvik etmesidir. Bu bir slogan şeklinde olabileceği gibi, pankart taşımak, şarkı söylemek, basın açıklaması yazmak, yazı yazmak, resim çizmek gibi çok çeşitli şekillerde olabilir. AIHM verdiği kararlarda özellikle nefret içerikli 
hiçbir eylemin AIHHS 10. maddesi kapsamında korunmayacağını özellikle belirtmektedir. Yine şiddet çağrısı, silahlı ayaklanma çă̆rısı, isyan çağrısı içeren eylemler de 10. maddenin korumasından yararlanmaz ...

AiHM'egöreağır eleştirisöz konusuolduğudurumlarileşiddetçağrısının birbirinden ayrllması gerekir. Mahkemenin özellikle üzerinde durduğu husus, eylemin şiddeti övmesi, teşvik etmesi veya meşru göstermesidir. Hatta mahkeme, Karataş-Türkiye kararında şiirde geçen şiddet içerikli ifadeleri sanatsal özgürlük nedeniyle korunması gerektiğini belirtmiştir. Buna ilişkin diğer bir örnek Arslan-Türkiye kararıdır. Yine Gül ve Diğerleri-Türkiye kararında, yasal bir toplantıda atılan basmakalıp sol sloganların şiddet içerseler bile fikir hürriyeti bağlamında korunması gerektiğini belirtmiştir. Sürek 3- Türkiye davasında ise mahkemeye göre, başvurucunun makalesinde Türkiye'nin bir bölümünü Kürdistan olarak nitelemesinde ve burası ile ilgili ulusal bir bağımsızlıktan bahsetmesi tek başına müdahaleyi hakl kılmaz, ancak aynı makalede kullanılan topyekun bir bağımsızlık mücadelesi istiyoruz TC güçlerine karşı yöneltilmiş bir savaş gibi sözlerin kendisini PKK ile özdeşleştirdiği ve bağımsızlığı gerçekleştirmek için silahlı güç kullanmaya teşvik ettiği için fikir hürriyeti kapsamında değerlendirilemez.

Bütün bu hususlar bir bütün halinde değerlendirildiğinde, bir eylemin terör propagandası olarak nitelendirilip cezalandırılması için mutlak surette şiddete veya silahlı direnişe ya da isyana teşvik ediyor olmasl, terör örgütünün varsa bu tarz eylemlerinin övülmesi ya da meşru gösterilmesi gerekir. Ă̆ır eleştiri sınırında kalan, siyasi nitelikli söylemlerin bu kapsamda değerlendirilmesi mümkün değildir. Ayrıca şiddet içerseler bile sanatsal faaliyetlerin daha özel olarak değerlendirilmesi ve AIHHS'nin 10. maddesinin bu durumlarda daha geniş yorumlanmasi gerekir. Kanun maddesinde her ne kadar cebir, tehdit ve şiddet ayrl ayrl belirtmiş, AIHM kararlarında ise şiddet olgusu üzerinde durulmuş ise de; cebir ve tehdit zaten şiddetin bir parçası olduklarından AIHM kararlarinda belirtilen şiddet olgusunun tehdit ve cebiri de içerdiği kabul edilmelidir.

... kararımızda PKKnın bir terör örgütü olduğu kabul edilerek bu konuda ayrıntıya yer verilmeyecektir. Yine Öcalan'in bu örgütün lideri olması nedeniyle birçok kişinin ölümünden sorumlu tutulduğu, yargılandiğı ve bu nedenle ceza aldı̆̆ ve cezasinin kesinleştiği sabittir... 
...Sanılar X ve Y'nin 17/03/2013 tarihinde ... yapılan nevruz kutlaması ve miting şeklindeki açık hava toplantısında konuşma yaptıkları, sanık X'in 'Size Kürt halkı önderi sayın Öcalan'ın selamını getirdim... Bugün de Kürdistan'da onun onurlu evlatlartyla onur duyuyoruz.' 'şeklinde ... sözler söyledikleri sanıkların savunmalarından, dosyada mevcut tutanak ve görüntü kayıtlarından anlaşılmıştır...

Sanık X yönünden yapılan değerlendirmede; sanığın terör örgütü lideri Öcalan'in fotoğrafinın asılı bulunduğu sahnede gerçekleştirdiğ $i$ konuşmasında söylediği 'Size Kürt halkı önderi sayın Öcalan'ın selaminı getirdim.... Bugün de Kürdistan'da onun onurlu evlatlarlyla onur duyuyoruz. 'şeklindeki sözleri ile terör örgütü liderini Kürt halkının lideri olarak göstererek terör örgütü PKK'yı ve yöneticisini meşru göstermeye çalışmış, ülke topraklarının bir bölümünü, terör örgütünün bölücü ideolojisinde yer aldiğı şekli ile Kürdistan olarak tabir etmiş ve bu suretle terör örgütünün propagandasın yapmıştır.

Bütün bu nedenlerle, her ne kadar sanıklar suçlamaları kabul etmemiş iseler de, sanıkların, hüküm fikralarında belirtilen gerekçeler ile birlikte yukarıda belirtildiği gibi, nevruz kutlaması ve miting şeklindeki açık hava toplantısında yaptıkları konuşmalar sirasında bölücü silahlı terör örgütü PKK ile yönetici ve üyeleri lehine, terör örgütü PKK'nın kullanmış olduğu şiddet yöntemini meşru gösteren, destekleyen ve öven, Türkiye Cumhuriyeti Devletinin güvenlik güçlerince yürütülen meşru ve haklt terörle mücadele operasyonlart ile ilgili olumsuz bir algı oluşturmaya çalışan yukarıda yazılı olduğu şekilde sözler sarf ederek ve Türkiye Cumhuriyeti Devleti topraklarının bir kısmını sözde Kürdistan olarak nitelendirerek örgütün bölücü ideolojisini yaymaya ve meşru göstermeye çalışarak TMK'nın 7/2. maddesinde düzenlenen terör örgütü propagandası suçunu işledikleri anlaşılmakla, ... cezalandırılmalarına ... karar verilmiştir."

Anayasa Mahkemesi bu olayda, X'in yaptığı açılamalarla ilgili olarak "şiddete teşvik ettiği kabul edilemez" değerlendirmesinde bulunmuştur. ${ }^{43}$

Anayasa Mahkemesi, 3.10.2019, BB 2018/38143 (Sırrı Süreyya Önder) (RG: 8 Ekim 2019/30912), pn. 73. 


\section{Bu Kararlara İlişkin Hukuki Değerlendirmelerimiz:}

1) Öncelikle belirtmek gerekir ki, bir toplantı ve gösteri yürüyüşü sırasında taşınan pankartlarda yer alan ifadeler, işaretler ve fotoğraflar ile, atılan sloganlar ve yapılan konuşmalar birbirinden müstakil olarak ele alınıp değerlendirmeye tabi tutulamaz. Toplantı ve gösteri yürüyüşü sırasında taşınan pankartlarda yer alan ifadeler, işaretler ve fotoğraflar ile, atılan sloganlar ve yapılan konuşmalar birlikte değerlendirilerek, terör örgütünün propagandası suçunun işlenip işlenmediğini tespit etmek gerekir. Bu itibarla, bir toplantı ve gösteri yürüyüşü sırasında atılan bir slogan, taşınan bir resim veya pankart müstakilen ele alınıp içeriğinin suç oluşturup oluşturmadığı hususunda bir değerlendirme yapılmamalıdır. Keza, toplantıda yapılan konuşma bir bütün olarak ele alınıp değerlendirmeye tabi tutulmalıdır. ${ }^{44}$

2) İşlenen fiilin, taşınan pankartın, atılan sloganın içeriğinin suç oluşturup oluşturmaması ile, suç oluşturan propaganda fillerini işleyen kişilerin ceza hukuku bakımından sorumlu tutulup tutulmaması gerektiği, bir toplantı ve gösteri yürüyüşü sırasında işlenen propaganda mahiyetindeki fiillerden dolay1 kimlerin sorumlu tutulması gerektiği, birbirinden ayrı hususlardır.

Eğer bir toplantı ve gösteri yürüyüşünde terörizmin ve terör örgütünün propagandası yapılmış ise, ceza hukuku sorumluluğu bakımından bu toplantı ve gösteri yürüyüşünü organize eden kişilerle bu toplantı ve gösteri yürüyüşüne katılan kalabalıkları birbirinden ayırmak gerekir.

Terörizmin ve terör örgütünün propagandasına dönüşen toplantı ve gösteri yürüyüşüne katılan kalabalık içinde yer alan ve özellikle çoğunluğu çocuklardan oluşan kişilerin, kitle psikolojisinin etkisiyle hareket ettikleri için, işledikleri fiillerden dolayı sorumluluklarını kusurluluk bağlamında ele alıp değerlendirmek gerekir. Başka bir ifadeyle, kalabalığ 1 oluşturan kişilerin bu toplantı ve gösteri yürüyüşü sırasındaki davranışlarını hukukun icaplarına göre yönlendirme yeteneklerinin olmadığını veya ceza hukuku sorumluluğunu gerektirmeyecek düzeyde azaldığını kabul etmek gerekir.

$\mathrm{Bu}$ nedenle, terörizmin ve terör örgütünün propagandasına dönüşen toplant1 ve gösteri yürüyüşüne katılan kalabalık içinde yer alan ve özellikle çoğunluğu çocuklardan oluşan kişiler hakkında bu toplantı ve gösteri yürüyüşü sırasında işledikleri fiiller dolayısıyla,

44 TAŞTAN, CHD, cilt III, sayı 6, Nisan 2008, sh.108.

412 Ankara Hacı Bayram Veli Üniversitesi Hukuk Fakültesi Dergisi C. XXV, Y. 2021, Sa. 2 
- açılmış olan davalarda, kusurunun bulunmaması sebebiyle ceza verilmesine yer olmadığı,

- $\quad$ yürütülen soruşturmalarda, yine aynı gerekçe ile kovuşturmaya yer olmadı $\breve{1}$,

kararının verilmesi gerekir. Keza, suç siyaseti gereğince, terörizmin ve terör örgütünün propagandası suçu ile ilgili olarak cumhuriyet savcılarının kamu davasını açma hususunda takdir yetkisiyle donatılması gerekir. Hatta, terörizmin ve terör örgütünün propagandasına dönüşen toplantı ve gösteri yürüyüşüne katılma konusunda yönlendirilen çocukların, suç siyaseti gereğince, soruşturma işlemlerine dahi tabi tutulmaması gerekir. Belirtilen hususlarda Cumhuriyet savcılarının yetki kullanabilmesini sağamaya yönelik olarak Ceza Muhakemesi Kanununda gerekli düzenlemelerin yapılmasına büyük ihtiyaç bulunmaktadır.

3) Bir toplant1 ve gösteri yürüyüşü sırasında atılan "Biji serok Apo" sloganından veya bu kişiye ait fotoğrafın taşınmasından hareketle, terörizmin ve terör örgütünün propagandası suçunun işlendiği sonucuna varılamaz.

Kişiler, Abdullah Öcalan'ı bir "lider" olarak kabul etseler bile, adı geçen kişi, mahkûm olduğu cezasını infaz kurumunda elan çekmekte olan bir hükümlüdür. İnfaz mevzuatımız hükümleri dikkate alındığında, cezasını infaz kurumunda çekmekte olan bir hükümlünün bir terör örgütüne fiilî liderlik yapması mümkün olmasa gerekir. ${ }^{45}$ Buna rağmen kişi, terör örgütü mensupları tarafindan "lider" olarak kabul edilebilir. Bu kabulü salt beyan, terör örgütü üyeliği veya terör örgütünün propagandası suçunun oluşumuna sebebiyet vermez. ${ }^{46}$

Ancak, terör örgütünün ismi zikredilerek ve özellikle faaliyetleri çerçevesinde icra edilen fiillerden bahisle slogan atılması, bu örgütün ve faaliyetlerinin "meşruiyeti" ve "ulviyeti" konusunda kişilerde izlenim oluşturma amacinı taşımaktadır. Bu içerikte pankart taşınmasıyla, slogan atılmasıyla propaganda suçunun oluşacağında kuşku bulunmamaktadır. ${ }^{47}$

45 ÖZGENÇ, İzzet: Suç Örgütleri, 13. bas1, Ankara, Ocak 2020, sh. 61 vd.

46 Bkz. Yargitay 16. CD, 10.7.2017, E. 2017/830, K. 2017/4745; Yargitay 16.CD, 18.11.2020, E. 2018/3952, K. 2020/5667.

47 Nitekim, Anayasa Mahkemesi tarafından, “Türkiye'nin her bölgesinde yaşanan ve yaşanmakta olan ă̆ı şiddet hareketlerinin faili, PKK'nın kurucusu ve söz konusu şiddet eylemlerinin birincil elden sorumlusu olan Abdullah Öcalan'l politik bir lider ve toplumsal so- 
4) Anayasa Mahkemesinin yukarıda iktibas etmiş bulunduğumuz 3.10.2019 tarihli ve 2018/38143 Bireysel Başvuru sayılı kararında, yapılan "açılklamalarının şiddete teşvik mahiyetinde olup olmadiğl yönündeki değerlendirmenin ... açıklamada bulunan kişinin kimliğine, açıklamanın zamanına ve muhtemel etkilerine ... bir bütün olarak baklarak yapılması gerektiği" belirtilmiştir. ${ }^{48}$ Yapılan açıklamanın şiddet içerip içermediğinin tespitinde, açıklamayı yapan kişinin kimliğinin dikkate alınması gerektiği yönündeki bu gerekçe, hukukilikten ve bilimsellikten uzaktır. Elbette ki somut tehlike suçlarında, açıklamanın muhtemel etkilerinin tespiti bağlamında yapıldığı ortam, yer ve zaman dikkate alınır. ${ }^{49}$ Açıklamayı yapan kişinin kimliği, açıklamanın şiddet içerip içermediğinin tespitinde değil, açıklamanın tehlikelilik boyutunun tespitinde dikkate alınabilir. ${ }^{50}$ Ancak, suç oluşturup oluşturmadığının tespitinde açıklamayı yapan kişinin kimliğinin

runların demokratik yollarla çözümünde meşru bir aktör olarak ilan eden söylemleri terör eylemlerinin failini öven ve dolaylstyla terör örgütünün cebir, şiddet veya tehdit içeren yöntemlerine başvurmayı teşvik eden mesajlar olarak değerlendirmemiştir.": Anayasa Mahkemesi, 3.10.2019, BB 2018/38143, pn. 64; Anayasa Mahkemesi, 5.11.2020, BB 2015/15672 (Candar Şafak Dönmez) (RG: 17 Aralık 2020/31337), pn. 67. Ayrıca bkz. Anayasa Mahkemesi, 8.1.2020, BB 2015/15088 (Mehmet Mihdi Bala) (RG: 17 Mart 2020/31071), pn. 56.

Buna karş1lı, "geniş güvenlik önlemleri altında yapılan toplantıda PKK'nın kurucusu (Abdullah Öcalan'ın) lider olarak benimsendiğine iliş̧kin sloganlar ile dışa vurulan düşünce açıklamasının zamansal açıdan şiddet tehlikesine neden olduğu değerlendirilmiştir. ... çatışma ortamının bulunduğu bir durumda başka bazı sloganlar yanında PKK terör örgütünün kurucusu ve örgütün eylemlerinin birinci dereceden sorumlusu olan (Abdullah Öcalan'ın) lider olarak gören sloganların atılması ile dışa vurulan düşünce açıklamasının zamansal açıdan șiddet tehlikesine neden olduğu değerlendirilmiştir.": Anayasa Mahkemesi, 8.1.2020, BB 2015/15088, pn. 58; Anayasa Mahkemesi, 5.11.2020, BB 2015/15672, pn. 67.

48 Anayasa Mahkemesi, 3.10.2019, BB 2018/38143, pn. 67; Anayasa Mahkemesi, 26.7.2019, BB 2018/17635, pn. 86; Anayasa Mahkemesi, 9.5.2019, BB 2017/36722 (Ayşe Çelik) (RG: 10 Mayıs 2019/30770), pn. 50; Anayasa Mahkemesi, 24.6.2015, BB 2013/568 (Ali Gürbüz ve Hasan Bayar) (RG: 13 Ağustos 2015/29444), pn. 64.

Anayasa Mahkemesinin bir başka kararında, kitap içeriğinin şiddeti teşvik edip etmediğinin tespitine yönelik olarak yapılan değerlendirmede, "yazarının kimliği”"nin de göz önünde bulundurulması gerektiği belirtilmiştir: Anayasa Mahkemesi, 25.6.2014, BB 2013/409 (Abdullah Öcalan), pn. 100, 101.

49 Bkz. AİHM, Sürek/Türkiye Kararı, 8.7.1999.

50 Bkz. AİHM, Zana/Türkiye Kararı, 25.11.1997. Ayrıca bkz. ARSLAN, İfade Özgürlüğü, İlkeler ve Türkiye, sh.190 vd.

AİHM bazı kararlarında siyasilerle ve hükümetle ilgili eleştirilerde ifade özgürlüğünün alanının daha geniş olduğunu belirtmektedir: Bkz. AİHM, Şener/Türkiye Kararı, (BB no: 26680/95) 18.7.2000; AİHM, Ceylan/Türkiye Kararı, (BB no: 23556/94) 8.7.1999. Dikkat edilmelidir ki, burada açıklamada bulunan kişinin kimliği değil, eleştiriye maruz bırakılan kişinin kimliği dikkate alınmıştır. Bu yönü itibarıyla söz konusu içtihatlar doğrudur. 
de ölçü alınmasını arayan bu "içtihat", iyi bir kürsü örneği oluşturmaktadır.

Anayasa Mahkemesi, terörizmin ve terör örgütünün propagandası suçunun bir "somut tehlike suçu" (!) olduğunu kabul etmektedir. ${ }^{51} \mathrm{Bu}$ anlayışa göre, bir toplantı ve gösteri yürüyüşünde yapılan açıklamaların içeriği ne olursa olsun, kalabalığın herhangi bir fiili saldırı olmaksızın ve hatta, bir somut saldırı tehlikesi doğmaksızın dağılması halinde, propaganda suçu oluşmayacaktır. ${ }^{52}$ Anayasa Mahkemesinin kararında, terör örgütünün "meşruiyeti" ve verdiği mücadelenin "ulviyeti" yönünde yapılan açıklamanın "şiddete yol açma potansiyelinin" 53 bulunmadığının hangi ölçütler dikkate alınarak belirleneceği hususu muğlak bırakılmıştır. Anayasa Mahkemesi bu kararları verirken, malum 2012 yılı itibarıyla başlatılan "demokratik açılım" veya namı diğer "çözüm süreci"nin oluşturduğu "müsamaha" ve "hoşgörü" ortamından yararlanarak iyice palazlanan terör örgütünün bir başkaldırı hareketi gerçekleştirdiği, bu başkaldırının bastırılması sırasında terör örgütü mensuplarının haricinde, çok sayıda kamu görevlisi ve sivil insanın hayatını kaybettiği, yaralandı̆̆ şehirlerin harabeye döndüğü, insanların göçe zorlandığı vakıalar1 $1^{54}$ göz ard1 edilmiştir. Aksine, Anayasa Mahkemesinin kararlarında, söz konusu "süreçte şiddet ve terör olayları önemli ölçüde azalmış" olduğu belirtilerek, ${ }^{55}$ sonuçları itibarıla yanıltıcı bir ifade kullanılmıştır. ${ }^{56}$

Anayasa Mahkemesinin kararına konu teşkil eden olayda, konuşmacının konuşmasında kullandığı “Kürdistan'da (Abdullah Öcalan'ın) onurlu

51 Anayasa Mahkemesi, 5.11.2020, BB 2015/15672, pn. 67; Anayasa Mahkemesi, 9.1.2020, BB 2015/19280 (Baver Mizrak) (RG: 17 Mart 2020/31071), pn. 47; Anayasa Mahkemesi, 8.1.2020, BB 2015/15088, pn. 52; Anayasa Mahkemesi, 3.10.2019, BB 2018/38143, pn. 64, 80; Anayasa Mahkemesi, 3.10.2019, BB 2015/4916 (Meki Katar) (RG: 18 Aralık 2019/30982), pn.5 3; Anayasa Mahkemesi, 26.7.2019, BB 2018/17635, pn. 84; Anayasa Mahkemesi, 9.5.2019, BB 2017/36722, pn. 47. Aynı yönde görüş için ayrıca bkz. TOPÇU, CHD, cilt X, say1 28, Ağustos 2015, sh.117.

52 Bkz. Yargitay 16. CD, 17.7.2015, E. 2015/2742, K. 2015/2316.

${ }_{53}$ Anayasa Mahkemesi, 3.10.2019, BB 2018/38143, pn. 80; Anayasa Mahkemesi, 26.7.2019, BB 2018/17635, pn. 127, b.

542015 yılının ortalarından itibaren girişilen başkaldırı hareketleri dolayısıyla çıkan karşılıklı silahlı çatışmalar sırasında ölen, yaralanan ve bu çatışmalar dolayısıyla göç etmek zorunda kalan kişi sayılarına ilişkin bilgi için bkz. Anayasa Mahkemesi, 9.5.2019, BB 2017/36722, pn. 10-13; Anayasa Mahkemesi, 26.7.2019, BB 2018/17635, pn. 9, 18.

55 Anayasa Mahkemesi, 3.10.2019, BB 2018/38143, pn. 69, 73.

56 Aslında Anayasa Mahkemesi, malum “çözüm süreci”nde PKK'nin Devletin hukuk dışı müsamahasından yararlanarak "bazı şehirlerde silah ve mühimmat yığınağı yap"tığını kabul etmektedir: Anayasa Mahkemesi, 26.7.2019, BB 2018/17635, pn. 9. 
evlatları" ifadesiyle PKK'nin faaliyeti çerçevesinde terör eylemlerinde bulunan silahlı kişileri övdüğü kuşkudan uzaktır. Keza konuşmada, malum “çözüm süreci”nin, esasında "masa"dan önce verilen silahlı mücadelenin bir başarısı olduğu ifade edilmiştir. Konuşmacı bu süreçle, mücadelenin "ölümlü kanlı bölümünün sonuna" gelindiğini ve fakat mücadelenin henüz sona ermediğini ve devam ettiğini ifade etmiştir. Konuşma içeriğinde, "savaşmak", "ölmek", "öldürmek" ifadelerinin kullanılmasından çekinilmemiștir. Anayasa Mahkemesinin kabullerinin ${ }^{57}$ aksine, konuşmacı bütün bu anlatımlarıyla, açıkça ismini zikretmemiş olmakla birlikte, PKK terör örgütünün bir halkın bağımsızlık ve özgürlük savaşı verdiği kanaatini dile getirmiştir. ${ }^{58}$

57 Anayasa Mahkemesi, 3.10.2019, BB 2018/38143, pn. 75, 79, 81, 82.

58 Anayasa Mahkemesinin, 26.7.2019 tarihli ve 2018/17635 bireysel başvuru sayılı kararına konu teşkil eden olayda, çeşitli kişiler tarafından imzalanan 11 Ocak 2016 tarihli bildiri metninde, Türkiye'de terörü sona erdirmeye yönelik olarak ve fakat, hukuki temeli olmayan yöntemlerle başlatılan malum "çözüm süreci"nin oluşturduğu ortamdan yararlanılarak başlatılan terör eylemlerinin önlenmesi amacıyla güvenlik görevlileri tarafından gerçekleştirilen uygulamaların eleştirisine yer verilmiştir. Bu eleştiriler kapsamında, güvenlik görevlileri tarafindan gerçekleştirilen uygulamalarla ilgili olarak "kasıtll ve planlı kıyım" ve "katliam" gibi ibareler kullanılmıştır.

$\mathrm{Bu}$ eleştiriler kapsamında dile getiriler güvenlik görevlilerine ve dolayısıyla Devlete izafe edilen uygulamaların gerçeklikle bağdaşıp bağdaşmadığına bakılmaksızın; bunların salt eleştiri konusu yapılması ceza hukuku sorumluluğunu gerektirmez. Bu eleştiriler bağlamında kullanılan ifadeler mübalağalı da olsa ve hatta, "kasıtlı ve planlı kıyım" ve "katliam" gibi ibareler kullanılmış olsa bile, salt bu nedenle ceza hukuku sorumluluğu cihetine gidilemez. Bu eleştiriler çerçevesinde "Devletin başta Kürt halkı olmak üzere tüm bölge halklarına karşı gerçekleştirdiği katliam ve uyguladığı bilinçli sürgün politikasından" söz edilirken, güvenlik görevlileri tarafından, yani Devlet eliyle gerçekleştirilen uygulamaların terör örgütüne, bu örgütün mensuplarına yönelik olmaktan ziyade, genel olarak "Kürt halki"nı hedef aldığı izlenimi oluşturulmaya çalışılmıştır.

Ancak, Anayasa Mahkemesinin söz konusu bireysel başvuru kararında değerlendirme dışı bırakılan 10 Mart 2016 tarihli açıklamada ise, 2015 yılı ortaları itibarıyla bazı illerimizde başlatılan yaygın terör eylemleri ve bu eylemlerin önlenmesine yönelik olarak güvenlik görevlilerinin uygulamaları "Kürt illerindeki savaş" olarak nitelendirilmiş̧tir.

Bu açıklamalarla, PKK terör örgütünün suç işlemek amacıyla kurulmuş ve faaliyet icra eden örgüt görüntüsünden ziyade, bir halkın bağımsızlı̆̆ için mücadele veren örgüt olduğu izlenimi oluşturulmak istendiği açıktır. Bu alanda önemli bir gerekçeyi, bu örgüte karşı askeri güç kullanılarak verilen mücadelenin oluşturduğunu belirtmek gerekir. PKK'ye karşı kara ve hava birlikleri tarafindan askeri silahlar kullanılarak verilen mücadele, milletlerarası kamuoyunda Türkiye Cumhuriyeti Devletinin bu örgütle "savaş hali"nde olduğu hususunda bir izlenim oluşturmaktadır.

Söz konusu 11 Ocak 2016 tarihli bildiri içeriğinde PKK terör örgütünün yaygın terör eylemlerini önlemeye yönelik olarak gerçekleştirilen özellikle sokağa çıkma yasağı uygulamalarının hukuki dayanaktan yoksunluğuna ilişkin olarak yer verilen eleştirilerin doğruluğuna rağmen; 10 Mart 2016 tarihli açıklamalar, dolaylı da olsa, "terör örgütünün; cebir, şiddet veya tehdit içeren yöntemlerini meşru gösterecek veya övecek ya da bu yöntemlere 
Anayasa Mahkemesinin bu kararlarını esas alacak olursak, faaliyeti çerçevesinde işlenmiş ve işlenmekte olan suçlardan bahsetmeksizin, bu suçlarla ilişki kurmaksızın, sadece güttüğü siyasi, sosyal ve ekonomik amaçlardan hareketle, PKK'nin "meşruiyeti” ve “ulviyeti” konusunda düşünce açıklamasının, suç oluşturmadığını kabul etmek gerekecektir!

Anayasa Mahkemesinin kabulüne göre; "terör veya terör örgütü ile bağlantılt

başvurmayı teşvik edecek şekilde propagandasını yapma” suçunu oluşturmaktadır.

Bu suretle, Türkiye'nin özellikle güneydoğu illerindeki yaygın terör eylemlerinin önlenmesine yönelik olarak güvenlik güçlerinin uygulamalarının savaş hukukuna ilişkin 12.8.1949 tarihli Cenevre Sözleşmeleri ve bu Sözleşmelere ek 8.6.1977 tarihli Protokoller hükümleri çerçevesinde değerlendirilmesinin yolu açılmak istenmektedir.

PKK mensupları, Avrupa'da barınma ve propaganda zemini buldukları ülkelerde, Türkiye Cumhuriyeti Devleti güvelik kuvvetlerinin özellikle güneydoğu bölgemizde ve bu bölgedeki sınır boylarında gerçekleştirdiği operasyonların, söz konusu Sözleşmeler hükümlerine göre, "bir devletin hükümet kuvvetleri ile hükümete karşı gelen silahlı gruplar arasında silahlı çatışmalar" olarak kabulü yönünde yoğun propaganda faaliyetinde bulunmaktadirlar.

Özellikle 8.6.1977 tarihli Protokoller, egemen ülke içinde, egemenlik kazanmak için yürütülen çatışmalar bakımından da, uluslararası nitelikte olmamalarına rağmen, savaş hukukuna ilişkin kuralların işletilmesini sağlamak amacını taşımaktadır.

Güvenlik kuvvetleri tarafından PKK'ye karşı yürütülen operasyonların "savaş" olarak nitelendirilmesinin ve silahlı çatışma hukukuna tabi kılınmasının en önemli sonucu, bu çatı̧̧malarda yakalanan PKK mensuplarının, söz konusu Sözleşmeler hükümlerine göre "esir", "tutsak" muamelesine tabi tutulmasıdır. Bu itibarla, PKK mensubu olup da işledikleri suçlar sebebiyle halen tutuklu veya hükümlü olarak ceza infaz kurumlarında bulunan kişilerin statüsü ve bu kişilere uygulanacak olan hukuk değişmiş olacaktır.

Keza, bu yöndeki kabul, PKK mensuplarının ellerinde rehin olarak tuttukları kamu görevlileri bakımından "esir mübadelesine" ilişkin sözleşme hükümlerinin uygulanması sonucunu doğuracaktır.

Anayasa Mahkemesinin bu ayrıntıların göz ardı edildiği söz konusu bireysel başvuru kararı, Türkiye'de de, PKK'nin Türkiye Cumhuriyeti Devleti güvenlik güçlerine karşı operasyonlarının savaş hukuku çerçevesinde değerlendirilmesi gerektiği yönündeki propaganda faaliyetlerinin önünü açmış olmaktadır.

Bu bağlamda özellikle üzerinde durulması gereken nokta, güvenlik güçlerinin PKK’ye karş1 operasyonlarının "savaş" olarak nitelendirilmesidir. Eğer bir savaştan söz ediliyorsa, bunun "tarafları"nın olması gerekir. Söz konusu operasyonları "savaş" olarak nitelendirme çabası içinde olanlar, PKK'yi Türkiye Cumhuriyeti Devleti karşısında "taraf" konumuna yükseltmektedirler ve PKK'nin nihai amacının "meşru”" olduğunu kabul etmektedirler.

Ancak belirtmek gerekir ki, bu değerlendirmelerimden, güvenlik güçlerinin terörle mücadele çerçevesinde icra ettikleri operasyonların hukuk zemininde icra edildiğini alelıtlak kabul ettiğim sonucu asla çıkarılamaz (ÖZGENÇ, Suç Örgütleri, 13. bası, sh. 138 vd.).

Keza belirtmek gerekir ki, terör örgütü, "pazarlı" malzemesi ve "canlı kalkan" olarak kullanılmak üzere, kamu görevlilerini kaçırarak, REHİN olarak tutmaktadır. Türkiye Cumhuriyeti Devletini temsil eden otorite tarafından, çoğunluğu güvenlik görevlisi bu kişilerle ilgili olarak "esir" ibaresinin kullanılması, Devlette bir akıl tutulmasının yansımasıdır. 
olsa bile içinde şiddete başvurmayı cesaretlendirici ifadeler yer almayan, terör suçlarının işlenmesi tehlikesine yol açmayan, terör örgütünün ideolojisi, toplumsal veya siyasal hedefleri, siyasi, ekonomik ve sosyal sorunlara ilişkin görüsşleri ile paralellik taşıyan düşünce açılklamaları terörizmin propagandası olarak kabul edilemez. Toplumsal ve siyasal ortama veya sosyoekonomik dengesizliklere, etnik sorunlara, ülke nüfusundaki farklıllklara, daha fazla özgürlük talebine veya ülke yönetim biçiminin eleştirisine yönelik düşüncelerin, ... devlet yetkilileri veya toplumun önemli bir bölümü için rahatsı edici olsa bile, açıklanması, yayılması, aktif, sistemli ve inandırıcı bir şekilde başkalarına aşılanması, telkin ve tavsiye edilmesi ifade özgürlügünün koruması altındadır." 59

Terör örgütünün amaçlarıyla örtüşse bile, terörle ve terör örgütüyle ilişkilendirilmeksizin birtakım siyasi, sosyal ve ekonomik sorunların gündeme getirilmesinin ve hatta bu sorunların terör örgütünü doğurduğunu, terör örgütünün bu sorunlardan güç aldığını, beslendiğini ve kendisine "meşruiyet" zemini oluşturmaya çalıştığını ifade etmenin suç oluşturmayacağı, izahtan varestedir. Ancak bu sorunlardan hareketle, terör örgütünün varlığının ve örgüt mensuplarının faaliyetlerinin "meşruiyeti" ve "ulviyeti" konusunda dolaylı da olsa açıklamalarda bulunulması, terörizmin ve terör örgütünün propagandası suçunu oluşturacaktır. ${ }^{60}$

Anayasa Mahkemesinin kararlarında bu ayırım göz ardı edilmiştir.

Belirtmek gerekir ki, terörizmin ve terör örgütünün propagandası suçu, somut tehlike suçu değil, soyut tehlike suçudur. ${ }^{61}$ Hatta, bu suçun temel şekli bakımındanaleniyetbirunsurolarak dakabul edilmemiştir.Anayasa Mahkemesi terörizmin ve terör örgütünün propagandası fiilinin suç oluşturmasıyla, her somut olay bağlamında bu suç nedeniyle kişilerin cezalandırılması gerekliliğini birbirinden ayıramamıştır. Anayasa Mahkemesine göre, terörizmin ve terör örgütünün propagandası, somut tehlikeye sebebiyet vermemiş ise, düşünceyi açıklama özgürlüğü çerçevesinde değerlendirilmelidir. ${ }^{62}$ Terörizmin ve terör

59 Anayasa Mahkemesi, 9.5.2019, BB 2017/36722, pn. 44. Ayrica bkz. Anayasa Mahkemesi, 3.10.2019, BB 2015/4916, pn. 54.

${ }^{60}$ Bkz. AİHM, Polat/Türkiye Kararı, (BB no: 23500/94) 8.6.1999.

${ }^{61}$ Bkz. YILDIRIM, Terör Örgütünün Propagandası Suçu, 2. bas1, sh. 273, 281 vd., 293; YURTLU, Gazi Ü. Hukuk Fakültesi Dergisi, cilt XX, say1 3, sh.425; ÖZBEK, Terör Örgütünün Propagandası Suçu, sh.138.

62 Ayrıntılı bilgi için bkz. ÖZGENÇ, İzzet: Türk Ceza Hukuku Genel Hükümler, Ceza Hukukuna Giriş, Suç Teorisi, Yaptırım Teorisi, Milletlerarası Ceza Hukuku, 16. bası, Ankara, Eylül 
örgütünün propagandas1 suçunun somut tehlike suçu mahiyeti taşıdığı kabul edilecek olursa, iki hususu araştırmak gerekecektir.

Bunlardan birincisi, bu açıklamanın yapılması üzerine terör örgütünün cebir, şiddet veya tehdit içeren eylemleri gerçekleştirmesi veya gerçekleştirme tehlikesinin ortaya çıkması gerekir.

İkinci ve en önemli husus ise, propaganda mahiyetindeki açılamalar ile terör örgütünün faaliyeti çerçevesinde gerçekleşen cebir, şiddet veya tehdit içeren fiiller veya bu tür fiillerin gerçekleşmesine ilişkin somut tehlike arasında nedensellik bağının bulunması ve bu bağın varlığının ispatlanması gerekir. Zira, somut tehlike suçunun oluşabilmesi için, failin gerçekleştirdiği fiilin bir objektif cezalandırılabilme şartı olan bu tehlikenin oluşumuna sebebiyet vermesi gerekir. ${ }^{63}$ Bunun uygulama bakımından ortaya çıkaracağı güçlük,

2020, sh. 705 vd.

63 Anayasa Mahkemesi, 15.2.2010 tarihinde Diyarbakır'da düzenlenen ve binlerce kişinin katıldığı bir toplantı ve gösteri yürüyüşü sırasında aşağıdaki içerikteki bildiriyi okuyan kişi hakkında terör örgütünün propagandası suçunu işlediği iddiasıyla açılan kamu davasında beraat kararı yerine davanın ertelenmesine karar verilmesiyle düşünceyi açılama hürriyetinin ihlal edildiğini kabul etmiştir (4.6.2015, BB 2013/9343 [Mehmet Ali Aydın] [RG: 1 Temmuz 2015/29403]):

“...Kürt sorununun çözümünde göstermelik, anayasal güvenceden yoksun, kolektif haklart tanımayan girișimleri kaygıyla izlemekteyiz. Kürtleri ve demokratik kamuoyunu kandırmaya yönelik hükümet sözcülerinin "Öcalan'ın muhatap alınması mümkün değil!..." açılamalarına yabancı değiliz. Benzer açılamaları yapanlar şu an nerelerde? Bugün; AKP'nin keçi inadına, anlamsız yaklaşımlarına yani, görmek istememesine karşın, Sayın Öcalan Kürt sorununda aktif bir siyasal öznedir ve çözüm gücüne sahiptir. İstediğiniz kadar muhatap değildir, olamaz deyin, dediklerini beğenin yada beğenmeyin, bu bir Türkiye gerçeğidir. ..... Ortadoğu'yu kirli emelleri doğrultusunda şekillendirmek isteyen uluslararası ve bölge güçleri Kürtlerin özgürlük ve demokrasi mücadelesini kendilerine engel gördükleri için 9 Ekim 1998 yllında Sayın Abdullah Öcalan'a yönelik bir komployu tezgahladılar. Özünde Kürt halkına genelde Ortadoğu halklarına özgürlük istemlerine yönelik bu komplo halkları birbirine düşürüp iktidarlarını pekiştirme amaçlyydl. Mevcut egemen sistem kaos yaratıp, ortaya çıkan durumdan vazife çıkarıp, kurtarıcı rolünde çözüm adına çözümsüzlüğ̈̈ geliştirmek, uygulana gelen klasik bir senaryodur. Ortadoğu'daki mevcut sistemin devam etmesi için, halkların boğazlaşması oyunu gerekiyordu! Bu doğrultuda Sayın Öcalan'ı Türkiye ye teslim ederek hedeflerine ulaşmak istediler. .... Ancak Sayın Öcalan'ın geliştirmiş olduğu barış̧̧l çözüm önerileri ile bu süreç engellendi. Bütün olumsuz zindan yaşam koşullarına, geliştirilen komplolara rağmen, o günden bugüne barış arayışı ve çabası her zamankinden daha güçlü devam etmektedir. Bu sürecin 11 yılını geride bırakırken, 12. yıla girmiş bulunmaktayız. Baskı cenderesi olarak tanımladığımız İmralı Cezaevi sistemi; hukuk dışı bir Guantanamo cezaevidir hemen kapatılmal, Sayın Abdullah Öcalan hemen serbest blrakılmalıdır. .... Sayın Öcalan'ın avukatları aracıllğglyla yaptı̆̆ cezaevi koşullarını içeren açıklamaları "Bir ölüm çukuruna atılmış gibiyim!...", "Solunum cihazına bağlanmış bir hasta gibiyim!..” sözlerini hatırlamayan yoktur. Yaşanan bu son durumun, toplumsal barışı ciddi bir biçimde tehdit ettiğini, büyük gerilimlerini sorumlu herkesin görmesi gerekir. .... 
izahtan varestedir. Anayasa Mahkemesinin bu kabulü karşısında, faaliyeti çerçevesinde cebir, şiddet veya tehdit içeren suçların sıklıkla ve yaygın bir şekilde işlendiği, işlenmekte olduğu bir terör örgütünün propagandasının yapılması halinde, nasıl bir yol izleneceği konusu muğlak kalmaktadır. Zira, bu durumda, somut tehlike esasen mevcuttur ve failin propaganda mahiyeti taşıyan açıklamaları ile bu somut tehlikenin ortaya çıkışı arasında bir irtibat bulunmamaktadir.

Anayasa Mahkemesinin söz konusu kararlarında terörizmin ve terör örgütünün propagandası suçuyla ilgili olarak yapılan bu değerlendirmeler, ceza hukuku bilgisinden uzaktır.

Yargıtay 16. Ceza Dairesinin de vermiş bulunduğu çeşitli kararlarda, terörizmin ve terör örgütünün propagandası suçunun oluşup oluşmadığının tespiti

Imral, sıradan bir cezaevi. Sayın Öcalan da herhangi bir tutsak değildir. Öcalan'ın sağlık koşulları, yaşamı ve güvenliği Türkiye'deki gelişmeleri derinden etkileyecek düzeyde kilit bir öneme sahiptir. Bu realitenin görülmesi ve buna göre hareket edilmesi, içinden geçmekte olduğumuz hassas sürecin en stratejik noktasını oluşturmaktadır. Sayın Öcalan, Türkiye'de tıkanmış olan siyasal sürecin önünün açılması için barış gruplarının gelişini ikinci kez önerdi. Habur sınır kapısında cenazeleri alan halkın barış gruplarının gelişiyle ilk defa çocuklarını kucaklaması, barlşa sarılması ortaya koymuştur, bu yüzbinler, çözümü̈n muhatabının bir kez daha İmralı olarak göstermiştir. Diğer yandan barış gruplarının gelişini hükümet çözüm olarak değerlendiremediği gibi asıl niyetinin tasfiye olduğunun açı̆̆a çıkması üzerine silbaştan açılımla ilgisi olmayan bir teslim olma sürecine girmiștir. Hükümetin Kürt açılımı sürecinde Kürtler devre dışı bırakılmak istenmektedir. Üç buçuk milyon Kürdün irade olarak kabul ettiği Sayın Öcalan'ın koșullarının ağırlaștırılması, DTP'nin kapatılması, siyasi yasakların getirilmesi, operasyonlarla demokratik siyasetin tüm yollarının Kürtlere kapatılmak istenmesi düşündürücüdür, kabul edilmezdir. ...Barış gruplarının çözüm için getirdiği mektuplar neden muhataplarına verilmiyor? Kamuoyuna açıklanmıyor, başbakanın bunu açıklaması gerekir. Hedef açılım değil tasfiyedir. Seçimlere kadar AKP kendi yarattı̆̆ Kürtlerle sonuç almak istiyor. AKP hükümeti samimi değildir. Diğer hükümetler gibi inkâr ve imhaya dayalı cumhuriyet politikası deșifre olmuştur. Bu açıllım geleneksel devlet politikalarını ifade ediyor. Bu açılımın, sorunu çözemeyeceği açıktır. Sayın Öcalan'ın yol haritasının açıklanması, muhataplarına verilmesi her geçen süre daha da önem arz etmektedir. Çözüm için bunun Türkiye demokrasisine, halklarına önemli katkıları olacağına inanıyoruz. Devlet aralıksız sürdürdüğ̈̈ askeri operasyonları durdurmalı, seçilmişlere yönelik operasyonlar durdurulmall. Türkiye'nin demokratikleşme zemininde Kürt halkının özgür iradesi esas alınarak müzakere başlamal, Demokratik sivil bir anayasanın hazırlanması elzemdir. Sorunu cesaretle tartışırsak çözüme kavuşabiliriz. Eşit, özgür, huzurlu bir yaşam için Türkiye'nin kendi barışını getireceğine dair inancımız tamdır. Sayın Öcalan, 6 m2'lik alanda 11 yıl yılmadan barışın tesisi için çalıştı. Sayın Öcalan'ın dikkate alınmadı̆̆ı, onun yok sayıldığg, diyalog kanallarının kapatıldı̆̆ bir süreç, Kürt sorununun çözümüne hizmet etmez, aksine çözümsüzlüğ̈̈ derinleştirir. Tecride ve yok etmeye dayall Amerika Guantanamosundan da geri Imrall sistemi halen ortadayken ve bu sistem daha da ağırlaştırılırken çözümün olması beklenemez. ...Sayın Öcalan'ın özgürlüğüne kavuşturulmasını kamuoyundan talep ederken, bu konuda Türkiye'de yaşayan tüm demokrat insanları duyarlı olmaya çağırıyoruz.". 
bağlamında yapılan değerlendirmede, açıklamada bulunan kişinin kimliğinin göz önünde bulundurulması gerektiği ifade edilmiştir. Keza, Dairenin kabulüne göre, yapılan açıklamanın "açık ve yakın tehlike”" oluşturup oluşturmadığının araştırılması gerekmektedir. ${ }^{64}$ Toplantı ve gösteri yürüyüşüne katılanların "olaysız" bir şekilde dağılmış olması, atılan sloganların ve taşınan pankart içeriklerinin somut tehlike oluşturmadığının dayanağı olarak gösterilmiştir. ${ }^{65}$

64 "Toplantı veya gösteri yürüyüşünde olsun veya olmasın; yazl veya sözler (atılan slogan, taşınan pankart veya giyilen üniforma) ile verilen mesajın şiddete çağrı, tahrik ve teşvik edici ya da silahl direnişe ve isyana davet șeklinde veya insanda saldirgan duygular olușturacak biçimde anlamsız bir nefret yaratarak şiddetin doğmasına uygun bir ortamı klşkırtacak nefret söylemi olup olmadiğ değerlendirilmeli, doğrudan veya dolayl şiddete çağrl var ise sanığın kimliği, konumu, konuşulan yer ve zaman gibi açık ve yakın tehlike testi bakımından analize tabi tutulmalıdır.": Yargitay 16. CD, 7.12.2020, E. 2020/6503, K. 2020/6027; Yargitay 16. CD, 7.12.2020, E. 2018/2814, K. 2020/6093; Yargitay 16. CD, 30.3.2017, E. 2015/6665, K. 2017/3586; Yargitay 16. CD, 15.6.2017, E. 2017/1334, K. 2017/4470; Yargitay 16. CD, 7.3.2017, E. 2016/1238, K. 2017/3434; Yargitay 16. CD, 23.2.2017, E. 2016/6853, K. 2017/1107; Yargitay 16. CD, 19.12.2016, E. 2016/3839, K. 2016/7571; Yargitay 16. CD, 2.11.2016, E. 2016/4798, K. 2016/5836; Yargitay 16. CD, 29.9.2016, E. 2016/1297, K. 2016/4872; Yargitay 16. CD, 9.6.2016, E. 2015/8605, K. 2016/3876; Yargitay 16. CD, 19.4.2016, E. 2016/437, K. 2016/2536; Yargitay 16. CD, 23.2.2016, E. 2015/8223, K. 2016/1218; Yargitay 16. CD, 9.2.2016, E. 2015/7842, K. 2016/945.

"somut olay değerlendirildiğinde "geliyor geliyor apocular geliyor" şeklinde attıklart sloganın ulusal güvenlik ve kamu düzeni üzerindeki potansiyel etkisinin sınırlı olduğu, ciddi bir tehlike yaratmadı̆̆ l, terör örgütünün cebir, şiddet veya tehdit içeren yöntemlerini meşru gösterecek veya övecek ya da teşvik edecek nitelikte olmadiğgl" sonucuna varılmıştır: Yarg1tay 16. CD, 31.5.2017, E. 2017/1383, K. 2017/4393.

Ancak Daire benimsediği bu ölçüte rağmen, bir milletvekili adayının "seçim konvoyunda bulunan ve "biji serok apo" (yaşasin önder apo), "bi can bi hun emtereye ey serok" (cantmızla kanımızla seninleyiz ey başkan) şeklinde slogan atan" kişi hakkında terör örgütünün propagandası suçundan kurulan mahkumiyet hükmünün onanmasına karar vermiştir: Yarg1tay 16. CD, 8.11.2016, E. 2016/1627, K. 2016/5889.

Keza, aynı Daire, "siyah sprey boya ile (apartman) garaj kapısina "PKK” yazıların yazma şeklindeki silahlı terör örgütünü öven maddi nitelikteki hareketlerin.. silahlı terör örgütüne yardım suçunu" oluşturduğunu kabul etmiştir: Yargıtay 16. CD, 27.2.2017, E. 2016/6095, K. 2017/1063.

65 Yargitay 16. CD, 30.3.2017, E. 2015/6665, K. 2017/3586; Yargitay 16. CD, 29.5.2017, E. 2017/1255, K. 2017/4604, Yargitay 16. CD, 11.7.2017, E. 2017/1384, K. 2017/4709; Yargitay 16. CD, 11.9.2017, E. 2017/1688, K. 2017/4856; Yargitay 16. CD, 9.11.2017, E. 2017/2046, K. 2017/5275; Yargitay 16. CD, 20.11.2017, E. 2017/2131, K. 2017/5379; Yargitay 16. CD, 23.2.2016, E. 2015/8223, K. 2016/1218.

Ancak, Dairenin bir kararında, aynı içerikte sloganların atıldığ rüyüşü sırasında karşıt görüşteki kişilerle toplantı ve gösteri yürüyüşüne katılanlar arasında taşlı sopalı çatışma çıkması durumunda terör örgütünün propagandası suçu bakımından nasıl bir yol izleneceği konusu muğlak bırakılmıştır: Yargıtay 16. CD, 20.9.2017, E. 2017/1874, K. $2017 / 4913$. 
5) Hukuk sistemimiz bakımından sorun, terörizmin ve terör örgütünün propagandası suçunun örgüt üyesi olan ve olmayan kişi tarafından işlenmesi arasında bir ayırım yapılıp yapılmaması, bir ayırım yapılacaksa bunun ceza hukuku sorumluluğuna etkisidir.

Propaganda fiilinin ayrıca suç olarak tanımlanmadığı hukuk sistemlerinde, bu tür fiiller dolayısıyla, terör örgütüne yardım, terör örgütünü destekleme dolayısıyla ceza hukuku sorumluluğunu cihetine gidilmektedir. ${ }^{66}$

Yardım fiillinden ayrı bir suç olarak terörizmin ve terör örgütünün propagandası suçunun tanımlandığı hukuk sistemlerinde, propaganda fiili terör örgütüne yardım mahiyeti taşımasına rağmen, genel norm-özel norm ilişkisis ${ }^{67}$ çerçevesinde, özel normun uygulanması yoluna gitmek, terör örgütü üyesi değilse kişiyi terörizmin ve terör örgütünün propagandası suçundan dolayı cezalandırmak gerekmektedir. Buna karşılık, terörizmin ve terör örgütünün propagandası fiilini işleyen kişi aynı zamanda terör örgütü üyesi ise, ceza hukuku sorumluluğunu belirleme bakımından bir sorunla karş1 karşıya kalınmaktadır.

Terörle Mücadele Kanununun 2006 yılında 5532 sayılı Kanunla yapılan değişiklikten önceki düzenlemesine istinaden, terör örgütünün propagandas1 suçunun örgütün üyesi olan bir kişi tarafından işlenmesi halinde, gerçek içtima hükümlerine göre, hem terör örgütü üyesi olmaktan hem de terör örgütünün propagandası suçunu işlemekten dolayı ayrı ayrı cezalandırılma yoluna gidilmekteydi. ${ }^{68}$

Oysa, yukarıda belirtildiği gibi, terörizmin ve terör örgütünün propagandası fiili, esasında örgüte maddi olmayan yardım mahiyeti taşıdığı için, TCK'nın örgüte yardım edenin örgüt üyesi olarak cezalandırılması gerektiği yönündeki düzenlemesi (m. 220, f. 7) karşısında; terör örgütüi üyesi olan kişinin, bu suçtan dolayı cezalandırılmasının yanı sıra, ayrıca örgüt propagandası suçundan dolayı mahkumiyeti yoluna gidilmemelidir. Başka bir ifadeyle, terörizmin ve terör örgütünün propagandası suçundan dolayı

66 İtalyan hukukuna ilişkin açıklamalar için bkz. Terörizm Suçlarıyla İlgili Karşılaştırmalı Çalışma Raporu, 25.03.2019, sh. 63 vd. Amerika Birleşik Devletleri hukukuna ilişkin açıklamalar için bkz. aynı eser, sh. $52 \mathrm{vd}$.

67 ÖZGENÇ, Türk Ceza Hukuku Genel Hükümler, 16. bası, sh. 112.

68 Zira, 3713 s. Kanun, m. 7, f. 2'nin 2006 yılında 5532 sayılı Kanunla yapılan değişiklikten önceki metnine göre, terör örgütünün propagandasını yapanların, "fiilleri başka bir suç oluştursa bile ayrıca" bu fikra hükmüne istinaden cezalandırılması gerekmekte idi. 
mahkûmiyet için, kişinin örgüt üyesi olmaması gerekir. ${ }^{69}$ Örgüt üyesinin terörizmin ve terör örgütünün propagandası mahiyeti taşıyan fiilleri işlemiş olması, örgüt üyeliğinden dolayı verilecek cezanın belirlenmesinde dikkate alınması gereken bir husustur. ${ }^{70},{ }^{71}, 72$

6)Terör örgütünün propagandasına dönüşen bir toplantı ve gösteri yürüyüşü bakımından ilk yapılması gereken, toplanan kalabalığın behemehal dağıtılması ve pankart gibi suç delili olabilecek nesnelere elkonulmasıdır.

Oysa, inceleme konusu yapmış bulunduğumuz Ceza Genel Kurulu kararlarına konu teşkil eden olaylarda kolluk görevlileri terör örgütünün propagandasına dönüşen bu toplantı ve gösteri yürüyüşlerine müdahale etmemişlerdir. Kalabalıklar kendiliğinden dağılmıştır. Malum “demokratik açılım süreci”nde, namı diğer "çözüm süreci"nde terör örgütünün propagandasına dönüşen toplantı ve gösteri yürüyüşleri ile ilgili olarak kolluğun yaptığ 1 şey, toplantı ve gösteri yürüyüşünün icrasını sesli ve görüntülü olarak kayda almak olmuştur.

Bilahare, malum süreçte izlenen yöntemin yanlışlı̆̆ının anlaşılması ve buna bağlı olarak siyasi atmosferin değişmesi üzerine, bu toplantı ve gösteri yürüyüşlerine katılan kişilerden sadece bir veya birkaçı hakkında terör örgütünün propagandasını yapmaktan dolayı soruşturma ve kovuşturmalar başlatılmış ve mahkûmiyet hükümleri kurulmuştur. ${ }^{73}$

69 ÖZGENÇ, Suç Örgütleri, 13. bası, sh. 123; TAŞTAN, CHD, cilt III, sayı 6, Nisan 2008, sh.105. Aksi yönde fikir için bkz TOPÇU, CHD, cilt X, sayı 28, Ağustos 2015, sh.114; YILDIRIM, Terör Örgütünün Propagandası Suçu, 2. bası, sh. 345; YURTLU, Gazi Ü.HFD, cilt XX, sayı 3, sh. 422; ÖZBEK, Terör Örgütünün Propagandası Suçu, sh. 169 vd. Suç Örgütleri kitabımızın eski basılarında, aynı yöndeki düşünceyi benimsemiştik. Ancak, bilahare bu düşüncemizin değişmesine rağmen, 13. bası, sh. 51, dn. 86'daki görüş değiştirilmeden kitapta kalmıştır.

70 Ancak belirtmek gerekir ki, örgüt üyesinin terörizmin ve terör örgütünün propagandası suçunu işlemesi halinde, hem üye olmaktan dolayı hem de propaganda suçundan dolayı cezaya hükmedilmesi yönündeki gerçek içtima uygulamasına devam edilmektedir. Bkz. Yargıtay 16. CD, 17.5.2018, E. 2018/440, K. 2018/1836; Yargitay 16. CD, 21.1.2019, E. 2018/873, K. 2019/286; Yargitay 16. CD, 11.4.2019, E. 2018/3355, K. 2019/3523; Yargitay 16. CD, 6.10.2020, E. $2019 / 9328$, K. 2020/4786

Buna karş11ık Yargıtay bazı kararlarında terör örgütü propagandası niteliğindeki eylemleri terör örgütüne üye olma suçunun delili olarak kabul etmektedir: Yargıtay 16. CD, 12.11.2020, E. 2020/4592, K. 2020/5505; Yargitay 16. CD, 20.10.2020, E. 2020/1484, K. 2020/5143. Bu son kararda, sanığın sosyal medyada yaptığı paylaşımların "örgütün cebir, şiddet veya tehdit içeren yöntemlerini meşru gösterecek veya övecek ya da teşvik edecek nitelikte olmamast, paylaşımların gerçekleştirildiği tarih, sanığın muhatap kitle üzerindeki etkisi, iddianame tarihi sonrası sanığın dosya içerisine yansıyan herhangi bir eyleminin olmaması hususları bir bütün halinde değerlendirildiğinde, sanığın propaganda suçuna konu edilen eylemlerinin örgüt üyeliği suçunun sübutuna esas teşkil eden süreklilik, çeşitlilik ve yoğunluk gösteren 
faaliyetler kapsamında kalan eylemler olduğu anlaşılmakla sanık hakkında terör örgütü propagandası yapmak suçundan ceza verilmesine yer olmadığına kararı verilmesi" gerektiği gerekçesiyle bozma kararı verilmiştir. İfade edelim ki, söz konusu olayda terörizmin ve terör örgütünün propagandası suçunun unsurlarının oluşmadığının kabul edilmesi karşısında, bu suçtan dolayı "ceza verilmesine yer olmadığı" kararının verilmesi gerektiğinden bahsedilmesi, CMK'nın 223.maddesinde yer alan düzenleme ile açıkça çelişmektedir.

71 Yargitay 16. Ceza Dairesinin 28.1.2019 tarihli ve E. 2018/4803, K. 2019/647 sayılı Kararına konu teşkil eden olayda; 24.6.2018 tarihinde yapılan 27. dönem milletvekili genel seçimlerinde milletvekili seçilen X, sosyal medya hesabından 20.1.2018 tarihinde yaptığı açıklamalarda, "her yer Efrin her yer Direniş, Afrin yalnız değil" yazılı fotoğrafı paylaşarak, altına "yezit kavminin hükmü sürsün diye Kürt ve Türk gençleri ölecek anaların yüreği acıyla inliyecek, çocuklar aç kalacak sivil insanlar can verecek", "yezit kavmi tecavüze devam ediyor, yüz elli çocuk hamile tarih böyle ahlaksızlık böyle kepazelik böyle rezalete tanık olmadı. Ahlaksızlığın her türlüsünü pervasızca yapıp yezit soylu din tüccarının fetvalarıyla kokuşmuş zihniyetlerini paklamaya çalışan yezit kavmi insanlığa karşı suç işliyor" şeklinde ifadeler kullanır.

$\mathrm{Bu}$ açıklamaları dolayısıyla $\mathrm{X}$ hakkında Ankara Cumhuriyet Başsavcılığınca düzenlenen 9.4.2018 tarihli iddianame ile,

- halk1 kin ve düşmanlığa alenen tahrik etmek,

- terör örgütünün propagandasını yapmak,

suçlarından dolayı TCK, m. 216, f. 1; 3713 s. TMK, m. 7, f. 2 hükümlerine istinaden cezalandırılması talebiyle Ankara Ağır Ceza Mahkemesine kamu davası açılmıştır. Mahkeme, X'e isnat edilen fiilin terör örgütünün propagandası suçunu değil, halkı kin ve düşmanlığa alenen tahrik suçunu oluşturabileceği değerlendirmesinden hareketle, bilahare milletvekili seçilen $\mathrm{X}$ 'in yasama dokunulmazlığından yararlandığını kabul ederek durma kararı vermiştir.

Yargıtay 16. Ceza Dairesi, terör örgütünün propagandası suçuna nazaran, halkı kin ve düşmanlığa alenen tahrik suçunun Anayasanın 14. maddesi kapsamına girmediği, bu nedenle X'in yasama dokunulmazlığı hükümlerinden yararlanması gerektiği, Ankara Ağır Ceza Mahkemesinin açılan davada vermiş bulunduğu durma kararının hukuka uygun olduğu yönünde içtihatta bulunmuştur.

Aynı şekilde Daire, pek çok kararında, terör örgütünün propagandası suçunun Anayasanın 14. maddesi kapsamına girdiğini kabul ederek, müsnet fiilin bu suçu oluşturduğu iddiasıyla açılan davalarda milletvekilliği dokunulmazlığının kaldırılmasına gerek olmadan yargılamaya devam edilmesi gerektiği yönünde içtihatta bulunmuştur: Yargıtay 16. CD, 19.6.2020, E. 2020/2705, K. 2020/3678; Yargitay 16. CD, 17.1.2020, E. 2019/11436, K. 2020/506; Yargitay 16. CD, 25.10.2019, E. 2019/5361, K. 2019/6434.

Keza, Yargıtay 16. Ceza Dairesinin diğer bir kararına göre, "milletvekili seçilmeden önce işlenen silahlı terör örgütünün propagandası suçu, Türkiye Cumhuriyeti Anayasasının 83/2. maddesinde işaret edilen ve 14/2. maddesinde gösterilen temel hak ve hürriyetlerin kötüye kullanılması niteliğinde olduğu kabul edildiğinden yasama dokunulmazlı̆̆ kapsamında sayılmayacaktır. Eylemin TCK'nın 301. maddesinde düzenlenen Türk Milletini, Türkiye Cumhuriyeti Devletini, Devletin kurum ve organlarını aşağllama suçu olarak nitelendirilmesi halinde yasama dokunulmazlığından yararlanacaktır.": Yargitay 16. CD, 1.11.2019, E. 2019/5366, K. 2019/6796.

72 Ayrıntılı bilgi için bkz. ÖZGENÇ, Türk Ceza Hukuku Genel Hükümler, 16. bası, sh. 690 vd. Terör örgütünün propagandası suçundan farklı olarak, terör örgütüne üyelik, bünyesindeki hiyerarşik ilişkiye dahil olarak örgütün desteklenmesini ifade etmektedir: BGH, Urteil vom 14.8.2009, 3 StR 552/08, kn. 13. 


\section{Sonuç:}

Terörizmin, barış esasına dayalı toplumsal düzen, hukuk toplumu bakımından arz ettiği tehlikelilik dolayısıyla, terör örgüitünün propagandası suçu, kanunlarda soyut tehlike suçu olarak tanımlanmıştır. Terör örgütünün propagandası fiili suç olarak tanımlanırken, muhatap alınan kişi sayısı, muhatap alınan kişilerin belirli veya belirsiz olması, muhataplar üzerinde etki meydana getirip getirmediği, alenen yapılıp yapılmaması, etki alanı

73 Yargitay 16. Ceza Dairesinin 25.1.2018 tarihli ve E. 2017/2948, K. 2018/162 say1l Kararına konu teşkil eden olayda; yüzleri kapalı vaziyette kişilerden oluşan 20-25 kişilik grup, araç trafiğine açık cadde üzerinde lastik yakarak caddeyi araç trafiğine kapatır; olay yerine gelen güvenlik güçlerine taşı saldırıda bulunur. Kolluk görevlilerinin takibi sonucunda bu grup içinde yer alan sadece bir kişi, henüz on üç yaşını tamamlamamış çocuk Ç yakalanır.

İlk Derece Mahkemesi, Ç’nin,

- Terör örgütüne üye olmak (TCK, m. 314, f. 2),

- Toplant1 ve Gösteri Yürüyüşleri Kanununa muhalefet (2911 s. Kanun, m. 32, f. 1; m. 33, f. 1 , bent a),

- Trafik güvenliğini kasten tehlikeye sokmak (TCK, m. 179, f. 1),

- Görevi yaptırmamak için kamu görevlisine karşı direnme (TCK, m. 265),

suçlarını işlediğini kabul ederek, hakkında bu suçlardan dolayı mahkumiyet hükmü kurmuştur.

Yargitay 16. Ceza Dairesi, yaptı̆̆ 1 temyiz incelemesi sonucunda, olayı sübut yönünden ele alarak, Ç hakkında kurulan bu mahkûmiyet hükümlerinin bozulmasına karar vermiştir (Ayrica bkz. Yargitay 16. CD, 10.12.2019, E. 2019/7315, K. 2019/8218; Yargitay 16. CD, 9.7.2019, E. 2019/3056, K. 2019/4913; Yargitay 16. CD, 3.4.2018, E. 2017/2692, K. 2018/1117; Yargitay 16. CD, 28.3.2017, E. 2016/6696, K. 2017/4564; Yargitay 16. CD, 14.11.2016, E. 2016/5472, K. 2016/5655).

Aslında bu olay bakımından sorun, bir sübut sorunu değildir. Bu olayda, on üç yaşında olan çocuk Ç’nin içinde yaşadığı toplum kesiminin sosyal, siyasi ve ekonomik koşullarının, kitle psikolojisinin etkisiyle bu fiilleri işlemeye sevk edilmiş olduğu ve bu durumdaki çocuğun işlediği suçlar bakımından davranışlarını hukukun icaplarına göre yönlendirme yeteneğinin mevcudiyetinden söz edilemeyeceği gerçeği göz ardı edilmiştir.

Hatta bazı durumlarda çocuğun, katıldığı toplantı ve gösteri yürüyüşünün hukuka aykırı olduğu, bu toplantı ve gösteri yürüyüşü sırasında taşıdığı pankartın, atılmasına iştirak ettiği sloganların içeriğinin suç oluşturduğu hususlarında bilinçten de yoksun olabileceğini göz önünde bulundurmak gerekir.

Karara konu teşkil eden olay bakımından sorun, TCK, m. 31, f. 2 hükmünün yanlış uygulanmasından ibarettir.

$\mathrm{Bu}$ tür yanlış uygulamalar, terör örgütünün insan devşirmesine hizmet etmekten, henüz orta öğrenim çağının başında olan çocukların terör örgütünün kucağına itilmesini sağlamaktan ve geleceklerinin karartılmasından başka bir sonuç ortaya çıkarmaz. Unutmamak gerekir ki, terör örgütlerinin en belirgin özelliği, özellikle orta öğrenim çağındaki çocukları istismardir.

Bir şehir merkezinde cereyan eden ve 20-25 kişinin katılımıyla gerçekleşen bu olayda sadece bir kişinin, on üç yaşındaki bir çocuğun yakalanabilmiş olması, ayrıca dikkati çeken bir durumdur. 
ve etkinliği gibi hususlar göz önünde bulundurulmaksızın, terör örgütünün varlığının ve faaliyetlerinin "meşruiyeti" ve "ulviyeti" konusunda ikna çabasında bulunmak, alelıtlak cezalandırmayı gerekli kılan bir fiil olarak değerlendirilmiştir (Strafwürdigkeit).

Buna karşılık, örneğin ahır duvarına "yaşasın PKK" sloganının yazılması halinde, gerçekleşen haksızlığın failin cezalandırılması yoluna gidecek ağırlıkta olmadığı değerlendirilerek, faile ceza vermeme yoluna gidilebilmelidir. Başka bir ifadeyle, somut olayda muhatap alınan kişilerin sayısının çok sınırlı olması, propaganda fiilinin etkinliğinin zayıflı̆̆ faile verilecek olan ceza miktarının belirlenmesi bakımından ve hatta, failin cezalandırılıp cezalandırılmaması bakımından göz önünde bulundurulmalıdır (Strafbedürftigkeit). ${ }^{74}$

Bu teorik düşüncelere dayalı olarak TCK'da, örneğin hırsılılı suçunda, suçun konusunun değerinin azlı̆̆ halinde, gerçekleşen haksızlık içeriği göz önünde bulundurularak faile bu suçtan dolayı verilecek olan cezanın miktarında indirim yapmak ve hatta hiç ceza vermemek yönünde hakime takdir yetkisi verilmiştir (m. 145). Dikkat edilmelidir ki, gerçekleşen haksızlığın failin cezalandırılması yoluna gidecek ağırlıkta olup olmadığını her somut olayın koşullarına göre belirlemek gerekir. Örneğin bir değneğin çalınması halinde de, hırsızlık suçu işlenmiş olur. Ancak değneğin değerinin azlığ 1 dikkate alınarak, gerçekleşen haksızlığın failin cezalandırılması yoluna gidecek ağırlıkta olmadığı değerlendirmesi yapılabilir. Buna karşılık, değneğin çalınmasıyla yaşlı bir insanın yürümekte ihtiyaç duyduğu dayanaktan yoksun bırakılmış ise, bu değerlendirmeyi yapmaktan sarfinazar ederek, hırsızlık suçundan dolayı cezalandırma yoluna gitmek gerekir.

Kanunda bir hüküm bulunmamakla birlikte, aynı değerlendirmenin mala zarar verme suçu bakımından da yapılabilmesi gerekir. Dikkat edilmelidir ki, ceza hukukundaki kıyas yasağı bu değerlendirmenin yapılmasına engel teşkil etmemektedir.

Terör örgütünün propagandası suçunda da, örgütün varlığının ve faaliyetlerinin "meşruiyeti" ve "ulviyeti” konusundaki ikna çabasının ifade ettiği haksızlığın

74 Ancak belirtmek gerekir ki, Avrupa İnsan Hakları Mahkemesi, içeriği esasında propaganda mahiyeti taşıyan yayının etki alanı sınırlı olduğu için, propaganda suçundan dolayı mahkumiyet hükmü kurulmasılyla ifade özgürlügünün ihlal edildiği yönünde içtihatlarda bulunmuştur: AİHM, Karataş/Türkiye Kararı, 8.7.1999; AİHM, Okçuoğlu/Türkiye Kararı, 8.7.1999; AİHM, Erdoğdu ve İnce/Türkiye Kararı, (BB no: 25067/94; 25068/94) 8.7.1999. 
failin cezalandırılması yoluna gidecek ağırlıkta olmadığı durumlarda cezalandırmaktan sarfinazar edilebilmelidir. ${ }^{75}$

$\mathrm{Bu}$ gibi durumlarda Cumhuriyet savcısına kamu davasını açmakta takdir yetkisi tanınarak, kovuşturmaya yer olmadığı kararı verebilmesinin yolunu açmak gerekir.

Görülmekte olan davalarda ise, işlenen fiilin suç olma özelliğini devam ettirmesine, terör örgütünün propagandası suçunu oluşturmasına rağmen, haksızlık içeriğini cezalandırmayı gerektirecek ağırlıkta görmediği takdirde, mahkemenin CMK, m. 223, f. 4, bent d hükmüne istinaden sanık hakkında ceza verilmesine yer olmadığı kararı vermesi gerekmektedir.

Önemle belirtmek gerekir ki, terör örgütünün propagandası mahiyetindeki bir fiil, hiçbir zaman düşünceyi açıklama hürriyetinin kullanılması bağlamında bir değerlendirmeye tabi tutulamaz. ${ }^{76}$

Terörle Mücadele Kanununun 7. maddesinde 2013 yılında 6459 sayılı Kanunla yapılan değişiklikle terör örgütünün propagandası suçunun uygulama alanının daraltılmak istendiği ve daraltıldığı muhakkaktır. Ancak, bu düzenlemeyle terör örgütünün propagandası suçu somut tehlike suçuna dönüştürülmemiştir. Doğru bulmadığımız bu değişikliğe göre, faaliyeti çerçevesinde işlenmiş ve işlenmekte olan suçlardan bahsetmeksizin terör örgütünün Türkiye'deki belirli hukuki, sosyal, siyasi ve ekonomik sorunların çözümü arayışlarında Devletin muhatap alması gereken bir "siyasi süje" olduğu yönündeki açıklamalar artık suç oluşturmamaktadır. ${ }^{77}$ Keza, terör örgütünün yöneticiliğini yapmış veya

75 Bu itibarla örneğin apartmanın garaj kapısına, bahçe duvarına " $P K K$ " veya "yaşasin $P K K$ " şeklinde yazı yazılması halinde terör örgütüne yardım etmekten dolayı mahkûmiyet hükmü kurulması yönündeki Yargıtay uygulamamız, sorunludur.

76 Ancak belirtmek gerekir ki, Avrupa İnsan Hakları Mahkemesinin içtihatları aksi yöndedir: AİHM, Gerger/Türkiye Kararı, 8.7.1999.

77 Önemle belirtmek gerekir ki, PKK terörüyle mücadeledeki hukuksuzluklardan, "Devlet eliyle, hukuk hiçe sayılarak yapılan katliamlar(dan), işlenen faili meçhul cinayetler"den bahsedilmesinin (örneğin CEMAL, Hasan: Gare katliamı... PKK'yı suçluyorum, kınıyorum, iktidarı da sorumlu tutuyorum ve silahlar artık susmalı diyorum, in: T24.com.tr, 20 Şubat 2021), ceza hukuku sorumluluğunu gerektiren bir yönü bulunmamaktadır.

Keza, Devlet eliyle maruz kalınan haksızlıkların, gözaltında, tutuklu veya hükümlü iken görülen işkence ve kötü muamelelerin, kişilerin "dağa çıkma" sebebini oluşturduğu yönündeki açıklamalar (örneğin CEMAL, Hasan: İ̧skence... "Genç olsam dağa çıkardım!”, in: T24. com.tr, 23 Şubat 2021), ceza hukuku sorumluluğunu gerektirmez.

Ancak, gazetecilerin terör örgütünün yöneticisi veya mensubu bulunan kişilerle yaptıkları röportaj içeriklerinin yayımlanmasının suç oluşturup oluşturmadığı üzerinde durmak gerekir 
(Bu konuda bkz. Yargitay CGK, 20.9.1993, E. 1993/9-157, K, 1993/190). Bu röportajlara ilişkin yayın içeriklerinde, örgütün faaliyetlerinin "meşru" olduğu ve örgüt mensuplarının "meşru" bir iş yaptıkları izlenimi oluşturan ifadelere yer verilmesi, propaganda suçu kapsamında değerlendirilmelidir. Bu yayın içeriklerinde örgüt yöneticisi veya sair mensubu kişilerin kişisel özelliklerinden bahsedilirken, icra ettikleri faaliyetin "meşru" ve kendilerinin "saygın" kişiler olduğu yönünde bir izlenim oluşturmaya yönelik ifadelerden kaçınılması gerekmektedir (örneğin BİRAND, Mehmet Ali: İşte Apo, işte PKK, in: Milliyet, 14-15-16 Haziran 1988; BİRAND, Mehmet Ali: $A P O$ ve PKK, 6. bas1, İstanbul 1992). Aksi takdirde, propaganda suçunun oluştuğunu kabul etmek gerekir.

Cemal'in, Abdullah Öcalan'la 1993 yılında yapmış bulunduğu röportaja ilişkin yayın içeriği, bu esaslar çerçevesinde bir değerlendirmeye tabi tutulmalıdır: CEMAL, Hasan: 1993 Nisan ayl, Bekaa'da Apo'yla sohbet: "Silahl mücadeleyle her iki taraf da kesin bir üstünlük sağlayamaz", Apo ekliyor: "Gelin şiddeti durduralım, siyasal çözüm yollarını devreye sokalım”, in: T24.com.tr, 25 Şubat 2021 (Erişim tarihi: 25.02.2021).

Söz konusu makalede, terör örgütüne Türkiye Cumhuriyeti Devletine karşı "silahlı mücadele" veren "taraf" sıfatı izafe edilmiștir. Röportaj mahiyetindeki makalede, PKK terör örgütünün Türkiye'de "meşru" ("legal") bir siyasi yapı olarak tanınması isteği, Abdullah Öcalan'a izafe edilen bir ifadeyle dile getirilmiştir.

Keza, Röportajda, PKK'nin katkısı olmaksızın Kürt sorununun çözümünün “zor” olduğu fikri, Abdullah Öcalan'ın ağzından ifade edilmiştir.

Her ne kadar Abdullah Öcalan hakkında terör örgütü kurmak ve yönetmek suçundan dolayı mahkûmiyet hükmü verilmemiş ise de, bu örgütün faaliyeti çerçevesinde "Devletin birliğini ve ülke bütünlügünü bozmak" suçunu işlediği kabul edilerek 765 sayılı TCK, m. 125 hükmüne istinaden mahkum edilmiş bir hükümlüdür. Söz konusu röportajın yayımlandığ 1 sırada adı geçen kişi hükümlü olarak ceza infaz kurumunda bulunsa bile, röportaj içeriğinde örgütün yöneticisi olarak düşünceleri kamuyla paylaşılmıştır.

Röportaj içeriğinde, Abdullah Öcalan'ın, toplumun Kürt kökenli kesiminin teveccühünü kazanmış, "küçücük bir çocuğu bile" etkileyebilen "ikna" gücüne sahip, "peygamberane" kişiliğinden bahsedilmektedir.

Her ne kadar, 1993 yılında yapılmış bir röportaj ise de, 2021 yılının şubat ayında yayın konusu yapılan metinde, "Dă̆ların PKK denetiminde olduğunu", "PKK'ya günlük militan katılımının 50 civarında olduğunu, bunun kısa sürede 100'e çıkabileceğini" belirten Abdullah Öcalan'ın, “Operasyon yapmak için Kuzey Irak'a falan ihtiyacımız kalmadı. İçerdeyiz artık. Dağda 10 bin militan dolaşıyor. Kuzey Irak'taki kamplar bizim için dinlenme yerleri..." şeklindeki ifadeleri aktarıldıktan sonra, "Siyaseti Hakkârili çobanın gündemine soktum" diye övündügü̈nden bahsedilmektedir.

Röportajda Abdullah Öcalan'a izafeten “ister silahla ister başka türlü barışı zorlayacağım” ifadesi kullanılmıştır.

Röportajda, Devletin terörle mücadelesi, uluslararası savaş hukukunun uygulanması gereken bir "silahlı çatışma" olarak nitelendirilerek, Abdullah Öcalan'a izafeten "savaş"tan ve PKK'nin "ateşkes" ilanından söz edilmiştir.

Bütün bu ifadelerin yanı sıra, Abdullah Öcalan'dan, “Türkiye'nin başına tarihinin en kanlı terör ve şiddet belasını sarmış olan bir insan" olarak bahsedilmiştir.

Röportajda, Abdullah Öcalan'a izafeten,

"Sivillere mesajım: Siyasî tekliflerinizi peş peşe sıralayın. Demokrasi paketinizi bekliyoruz. Askerlere mesajım: Özel savaşı durdurun" 
ettikleri suçlardan bahsetmeksizin, Türkiye'deki belirli hukuki, sosyal, siyasi

dedikten sonra ekliyor:

"Eğer üstümüze gelinmezse, yani operasyonlar durdurulursa... Yaygın kitle tutuklamaları, faili meçhul cinayetler durdurulursa... Köy boşaltmalarına son verilirse... O zaman bizim de şiddeti tırmandırmak gibi bir politikamı olamaz. Çünkü bütün bunlar zımnen de olsa 'ateşkes yürürlüktedir' anlamına gelir."

Ateşkes süresi...

"Geçen bir ay içinde iyi niyet görmedik. Eğer üstümüze sert gelinirse, kesinlikle misillemeler yapacağız. 'Zayıflamışlardır; biraz daha bastırırsak işlerini bitiririz' diye bir yaklaşım sezersek, meşru savunmamız ve misilleme hakkımızı kullanacağız. Silahlarımız yerli yerinde duruyor. PKK silahını bu koşullar devam ettikçe bırakmaz. Stmsıkı elinde tutar. Fakat politikaya da en az bunun kadar ă̆ırlık verir."

"Mevcut şartlar değişmeden dağdan inmek, silah bırakmak intihar olur"

diyor Apo;

“Bu koşullarda 'Dağdan in, teslim ol!' lafina kargalar güler. Bu ülke kendi başbakanını asmış... 'Ben bir koyunum, gel beni boğazla!' diyemeyiz. 'Dağdan in, teslim ol, biz senin için iyi düşünüyoruz.' İnsem, beni lime lime etmez misiniz? Önce güvence ver! Önce demokrasi yap! O zaman silahlar köklü susar. Kürtler tarihlerinde çok kandırıldılar. Bize politika alanı açın. Bana inandırıcı güvenceler verin. .... Ama olmazsa, ben silahlı mücadelenin Allah'ını yaparım."

"Silahlı mücadeleyle her iki tarafin da kesin bir üstünlük sağlaması olanaksız. Ama silahlı mücadeleyle bir yerde denge sağlanacak ve o noktada siyasal çözüm yolları devreye girecek. Gelin şiddeti durduralım! ... Türkiye sorunu böyle götüremez. Bu yolla iflasa gidiyor Türkiye."

açıklamalarına yer verilmiştir.

Her ne kadar Abdullah Öcalan'a izafe edilmiş olsa bile, yapılan bu açıklamalarla PKK'nin faaliyeti çerçevesinde "meşru savunma hakkı”nın kullanıldığı ifade edilmiştir. Silahlı mücadelenin siyasi çözüm için kendileri bakımından vazgeçilmez bir yol olduğu vurgulanmıştır.

Ezcümle, yapılan bütün bu açıklamalar, terör örgütünün propagandası mahiyeti taşımaktadir.

Yazar, bu yazı dizisinin ilerleyen aşamalarında İsmail Beşikçi'ye izafeten, PKK'nin bir terör örgütü değil, meşruiyet zemininde oluşmuş bir siyasi organizasyon olduğu izlenimi oluşturan ifadelere yer vermektedir: "PKK'nin övgüye değil, eleştiriye ihtiyacı vardır", "PKK'yi ilerletecek olan eleştiridir" gibi. Yazı içeriğinde sürekli olarak adeta uluslararası hukuk kavramları olan "taraf"lardan, "karşılıklı çatışma"dan ve karşılıkl "silah bırakma"dan söz edilmektedir: CEMAL, Hasan: "PKK tek başına silah bıraksa, Kürt halkının mücadelesine hizmet eder; çünkü karşı tarafin elindeki silahı düşürür”, Devletle PKK arasında, iki ateş arasında kalan Kürt aydinlart..., in: T24.com.tr, 2 Mart 2021.

Oysa PKK bağlamında, bir karşılıklı çatışma değil, bir terör faaliyeti ve Devletin bu terör faaliyetine karşı mücadelesi söz konusudur. Önemle belirtmek gerekir ki, Devletin bu terör faaliyetine karşı elbette hukuk dış1 uygulamaları olmuştur. Bkz. örneğin CEMAL, Hasan: Gece yarlsı telefon: "Olay doğru, jandarma hem dövmüş köylüleri hem de bok yedirmiş..." Günlügümün sayfaları arasında, 37 yll öncesi, in: T24.com.tr, 27 Şubat 2021. Bu uygulamalar dolayısıyla sorumluluk tartışmaları yapılabilir. Ancak bu hukuk dışı uygulamalar, terör faaliyetine asla meşruiyet kazandırmaz. 
ve ekonomik sorunları müzakere etmek, bu kişilerin söz konusu sorunların çözümüne yönelik görüşlerini yayımlamak, artık suç oluşturmamaktadır. ${ }^{78}$

İnceleme konusu yapmış bulunduğumuz yüksek mahkeme kararlarında ifade edildiği üzere, terör örgütünün propagandası suçunun bir "somut" tehlike suçu olduğu yönündeki hukuki temeli bulunmayan değerlendirmeye sadik kalınırsa, terörle mücadelede artık çok geç olan koşullarla karşı karşıya kalınacağı kaçınılmaz olur.

Gerçeklik temeli olsun veya olmasın, Türkiye'deki belirli hukuki, sosyal, siyasi ve ekonomik sorunlarla ilgili müzakerelerde bulunmanın, belirli sorunların çözümüne ilişkin görüşlerin paylaşılmasının düşünceyi açıklama hürriyetinin kapsamında değerlendirilmesi gerektiği ve suç oluşturmayacağ1, izahtan varestedir. Ancak, bu sorunlardan hareketle terör örgütüne "meşruiyet" kapısı aralamaya çalışmak, asla bir özgürlük sorunu olarak ele alınamaz.

Kişinin, terör örgütünün işaretlerini, örgüt yöneticilerinin fotoğraflarını, örgütün veya yöneticilerinin mesajlarını içeren matbu malzemeyi üzerinde veya evinde başlı başına bulundurması, terör örgütünün propagandası suçunu oluşturmadığı gibi, terörörgütü üyeliğinden dolayı sorumluluğunu gerektirmez. Bu durum, kişinin terör örgütüne ve örgüt yöneticilerine olan sempatisini ifade etmektedir. Terör örgütüne, örgütün yöneticilerine, üyelerine, amaçlarına salt sempati duymak, örgüt bünyesindeki hiyerarşik yapıya dahil olunmadı̆̆ örgüte yardım edilmediği veya örgütle bağlantılı bir suç işlenmediği takdirde, örgüt üyeliğinden dolayı sorumluluğu gerektirmez. Ancak, terör örgütünün işaretlerinin, örgüt yöneticilerinin fotoğraflarının, örgütün veya yöneticilerinin mesajlarını içeren matbu malzemenin dağıtılmak üzere, yani örgütün veya faaliyetlerinin "meşruiyeti" ve "ulviyeti” konusunda başkalarını ikna amacıyla kullanılmak üzere bulundurulması, teşebbüs aşamasında kalmış terör örgütüne yardımdan dolayı cezalandırılmayı gerektirir. ${ }^{79}$

Terör örgütünün propagandası suçunun oluşup oluşmadığının belirlenmesinde failin kimliğinin bir önemi bulunmamaktadır. Ancak, propaganda fiilinin

\footnotetext{
78 Anayasa Mahkemesinin 25.6.2014 tarihli ve 2013/409 Bireysel Başvuru sayılı kararı, bu bakımdan dikkat çekicidir. Karara konu teşkil eden kitabın Türkiye'de yayımlanması gündeme geldiğinde, ilgili Bakanın şahsıma sorusu üzerine, kendisine, söz konusu kitap çalışmasının "yazar" olarak adına izafe edildiği şahsın hükümlü olarak cezasını çekmek üzere uzun süreden beri infaz kurumunda bulunduğunu, Adalet Bakanlığından söz konusu kişinin bu süre zarfında infaz kurumunda böyle bir çalı̧̧ma yapmış olup olmadığı hususunun sorulmasını önermiştim.

79 ÖZGENÇ, Suç Örgütleri, 13. bası, sh. 45, dn. 81 .
} 
etkinliğinin belirlenmesi bakımından muhatap alınan kişi sayısının fazlalığı, muhatap alınan kişilerin özellikleri ve fail ile muhatap aldığ 1 kişiler arasındaki ilişki dikkate alınmalıdır. Başka bir ifadeyle, terör örgütünün propagandası suçunun soyut tehlike suçu olmasına rağmen, bu suçtan dolayı verilecek temel cezanın belirlenmesinde propaganda fiilinin etkinliği ve dolayısıyla, fail ile muhatap aldığ 1 kişiler arasındaki ilişki, failin sosyal konumu göz önünde bulundurulmalıdır.

Terör örgütlerinin istismarına en fazla açık olan yaş grubunu çocuklar oluşturmaktadır. Çocuklar hakkında terör örgütüyle ilişkilendirilerek soruşturma ve kovuşturma yapılması, bu istismara, çocukların örgüte kazanılmasına önemli bir zemin oluşturmaktadır. Bunun önüne geçebilmek için, çocuklar hakkında terör örgütüyle ilişkilendirilerek, özellikle terör örgütünün propagandası, hukuka aykırı toplantı ve gösteri yürüyüşüne katılmak dolayısıyla soruşturma ve kovuşturma yapmamak gerekir. Terör örgütlerinin etki alanına giren çocukları topluma kazanmaya yönelik eğitim programlarına tabi tutmak, korumak ve desteklemek gerekir. Bu alanda mevzuat sorunumuz bulunmamaktadır. Bu alanda duyarlılığa, ilgiye, sorumluluk bilinciyle hareket eden kamu görevlilerine ihtiyaç bulunmaktadır. 
